\title{
Toddy Business among the Indian Labour in Colonial Malaya, 1900-1957
}

\author{
Dr. Parameswari Krishnan \\ Ph.D. in Malaysian History \\ Lecturer \\ Education Department \\ Faculty of Education and Social Sciences \\ University of Selangor \\ Malaysia \\ Dr. J. Hinduja Jayer Raman \\ Ph.D. in Social Science \\ Indian Studies Department \\ Faculty of Arts and Social Sciences \\ University of Malaya, Kuala Lumpur
}

The majority of South Indians that migrated to Malaya were generally illiterate and they were placed in estates and plantations. Here, the labourers were not provided with adequate amenities and even healthy activities. In this background, toddy was widely introduced by the British government to pacify the labourers. The coming of the Indian workers was highly beneficial to the British government on two fronts, namely the profit made from the rubber industry, and profits made from the sale of toddy to the Indian immigrants. This article focuses on the toddy business that flourished in Malaya among the Indian labourers during the colonial era. The authors discuss in detail the parties that benefit from the toddy business, as well as the parties that suffered from its consumption. This study found that the main retailers and drinkers of toddy in Malaya were Indian labourers, the majority of whom originated from South India.

Keywords: toddy, samsu, licensed toddy business, unlicensed or illegal toddy business Indian labour, Malaya, British Government.

\section{Introduction}

This study is focused on the toddy business that occurred among the Indian community residing in plantation areas during the colonial period of 1900 to 1957. The Indian communities referred to in this essay are Indian communities in estates, or those that worked in rubber and coconut plantations in Malaya in 1900-1957. This group is markedly different from Indians that served in government departments, or middle-class Indians involved in other forms of occupation. Even though undeniably they were also involved in the toddy business, for the sake of this study, the focus is mainly on the plantation communities. This decision is based on a number of things. Firstly, the estate Indians are more identifiable and apparent in the toddy business compared to town or city Indians due to the sheer number of estate toddy shops at the time. Secondly, laws and regulations regarding toddy were formed with this particular group in mind. The two aforementioned points justify the article's intent of focusing on the estate Indian community in Malaya.

The arrival of the immigrant communities to Malaya is interesting. The arrival and settlement of the Chinese in Malaya is linked to the opium trade and the emergence of secret societies, while the arrival of the Indians is linked to toddy and samsu. Around $90 \%$ of the Indian labour migrants to Malaya were illiterate. ${ }^{i}$ Based on the estate system in Malaya, the Indian labourers were placed in plantations, and they entire lives were limited to that particular area. They were not provided with comfortable facilities and were not allowed room for recreation and other social activity. The only leisure afforded within this condition of social restriction was the toddy shop. The toddy shop served as an important 'social institution' to the estate community at the time, as they would then spend their time drinking toddy. This condition led to the forging of close bonds between the estate labourer and the toddy shop. The British and estate employer, realising this bond, allowed for the establishment of toddy shops in each plantation. 
The Indians have a significant function in the development of toddy in Malaya, through their involvement as retailers and drinkers of toddy. As toddy sales was highly profitable, rubber estate employers provided toddy shops to maintain their position in the plantations. To the British, 'toddy' served as a source of double benefit, the first being profit and the second being labour control. Further, British in Malaya were more favourable towards the opening of toddy shops as an incentive to attract Indians to come and work in Malaya. During the colonial period, estate employers were generally Europeans, and they found it simpler to exploit an intoxicated labour class. As a result, they supported the opening of estate toddy shops in a big scale in estates. The employers excuses that the toddy shop should be opened to control the labour movement and to prevent them from engaging in other social problems. Even employers were aware that managing toddy addicted labourers was easier. The wide-spread influence of toddy had brought about enormous social implications among Indian labourers. Family and community institutions fell into disarray.

This study attempts to answer a number of important questions. What is toddy? Who was involved in toddy retail? Who was the focus customer of toddy sales? How many types of toddy sales existed? et cetera. There questions are important in revealing interesting information on the large-scale toddy business during the colonial period in Malaya. It is evident that studies on toddy among estate Indian labourers in Malaya would be incomplete without a proper discussion on the sale and business of toddy.

\section{Toddy Consumption History}

Consumption of toddy among the Indians is a custom brought from the motherland. The Tholkaapiyam is the earliest and oldest Tamil epic. Nacchinaarkiniyar, a figure that wrote the commentary on this epic stated the Indians during the time of Tholkappiyar (author of the work) do consume toddy. ${ }^{\text {ii }}$

During the classical or sangam period in India evidence pointed to the Tamils practising toddy drinking. In the early sangam period, toddy was called Pathaniir or Veriiniir in Tamil, meaning sap or intoxicants. In this period, toddy is not prohibited but practised in India across the class divide. All Indians, from the highest to lowest class, were involved in this activity. The injunction against toddy did not exist, and even women and children were not exempt from this habit. ${ }^{\text {iii }}$

Almost everyone did not view toddy as a negative influence on their lives. Kings and commoners, poets, men and women, and hardworking labourers drink toddy. This information was taken from the sangam epics, such as Naanmani Kadigai $\left(97^{\text {th }}\right.$ poem: line 1), Innaa Natpathu $\left(9^{\text {th }}\right.$ poem: line 1$)$, Perumpaanaatrupadai $\left(142^{\text {nd }}\right.$ poem), Sirumpaanaatrupadai ( $234^{\text {th }}$ poem), Aganaanuuru (348 ${ }^{\text {th }}$ poem: line-7), Puranaanuuru (392 ${ }^{\text {nd }}$ poem: line-16). In the Puranaanuuru (113 ${ }^{\text {th }}$ poem), there is information on the deeds of kings serving toddy as the main beverage to the poets and bards in feasts. Furthermore, the Puranaanuuru $\left(262^{\text {nd }}\right.$ poem $)$ touched on the kings providing toddy to war heroes. The people, like their king, also serve toddy in feasts. An interesting fact is the people in the sangam era put toddy in front of the Nadukkal or graves of fallen soldiers before the prayer ritual (Puranaanuuru, $232^{\text {nd }}$ poem $)$. In the Puranaanuuru $\left(360^{\text {th }}\right.$ poem $)$, it mentioned the Indian ritual of serving "toddy and food" to the dead before cremation. In total, the sangam era Indians view the toddy as a joy-bringing beverage. ${ }^{\text {iv }}$

In the Vetham or Veda period, there were 24 types of alcohol beverages. Among them was the Somam or alcohol used for sacrificial purposes. In this period, the Tamil epic Puraana recorded the sin of toddy consumption. One of the oldest epics in Hinduism, the Thirumanthiram $\left(315^{\text {th }}\right.$ poem) states the toddy drinker cannot achieve moksha or spiritual enlightenment. ${ }^{\mathrm{v}}$

The Thiruvalluvar era follows. ${ }^{\text {vi }}$ During this period, Thiruvalluvar wrote the great epic, the Thirukkural. During this period, the toddy lost its high position, and is now considered the bane of society. In this work, he mentioned the harms of toddy in (poems / kural 1201 and 1288). ${ }^{\text {vii }}$ According to Valluvar, the toddy is poison and toddy drinkers are poison drinkers. This is mentioned in Thirukkural, poem / kural 926 . $^{\text {vii }}$

As previously discussed, the culture of toddy consumption in India existed since the early days. The kings see it as the drink of 'honour'. The people use it in rites and rituals. However, societal perception of toddy changed in later periods. During Thiruvalluvar's era, toddy is considered a bane on society. However, toddy consumption continues to exist among Indians until the present.

The culture of toddy consumption is not new in Malaya, but it is a continuation in line with labour arrival in new places. The toddy-drinking habit among Indian labourers in Malaya is wide spread during the British colonial period. Those who did not drink in India due to societal sanctions, turn to addicts after their arrival to this country with the availability of the beverage. ${ }^{\mathrm{ix}}$ 
If we trace the tradition of toddy consumption among the Indian labour, it has existed in the motherland, but according to S. Arasaratnam in his book Indians in Malaysia and Singapore, the majority of Indian labourers in Malaya fell to the toddy in Malaya, not in India. They turn to toddy due to the affordability and availability of toddy, through the toddy shops in most estates in Malaya. They could not have the same accessibility in their home villages in India. There were even controls on alcohol in their villages, coupled with caste injunctions. The Brahmins were prohibited from drinking toddy. The estate managers in India only allowed for the establishment of toddy shops in each district. Toddy shops in India were established in their plantations so they would not need to go far to find the beverage. ${ }^{x}$ However, K. Kalaimuthu rejects S. Arasaratnam's view and argues that toddydrinking among Indian labourers in Malaya was part of the culture brought from India. ${ }^{\mathrm{xi}}$

Even with differing views, the reality was excessive consumption of toddy occurred in Malaya due to the opening of toddy shops near the residence of labourers and in almost all estates with divisions. This situation meant most labourers in an estate started to consume toddy. No Indian labourer was immune from toddy. This could be seen from the Annual Report of The Agent of The Government of India In British Malaya For The Year 1930, "Tody drink is a newly acquired habit to many of the Indian labourers in Malaya. The temptation provided in estates at their very doors is the real reason for this. Many estates have as many toddy shops as there are Divisions on them. Toddy has become a daily routine with the Indian labourers in spite of the fact that it was considered a luxury and excluded from their monthly budget. Many of them spend their earnings at toddy shop without providing enough for their food and other necessaries of life. Where the toddy shops were little far away from the labourers' lines, there were many total abstainers and occasional drinkers, whereas the location of toddy shop close to their lines has converted almost the whole labour force into habitual drinkers..."xii

In the estates, an Indian labourer would generally drink three types of toddy, the fresh toddy, week-old toddy, and three-week old toddy. Indian labourers usually drank the old or stale toddy, a week old, or even older. They rarely get to drink fresh toddy. This is due to the work of certain groups driven by profit, such as toddy sellers that mix fresh toddy with other ingredients. Meanwhile, the Chinese samsu they consume were Fresh, 'Sam Ching', and 'Seung Ching' samsu. Though samsu was sold in estate sundry shops, but most Indian labourers drank illicit samsu as it was cheaper and contain high alcohol content. However, samsu could only be consumed occasionally and not as often as toddy, ${ }^{\text {xiii }}$ due to samsu being worse than toddy. ${ }^{\text {xiv }}$ Other than toddy and samsu, only a few Indians drink other alcoholic beverages such as brandy, whiskey, rum, and gin, especially during pay day in the estate. ${ }^{\mathrm{xv}}$ The following table showed the explanation of beverages which consumed by labourers in Malaya.

Graph 1 Percentage of alcohol content in alcoholic beverages in Malaya during the colonial era.

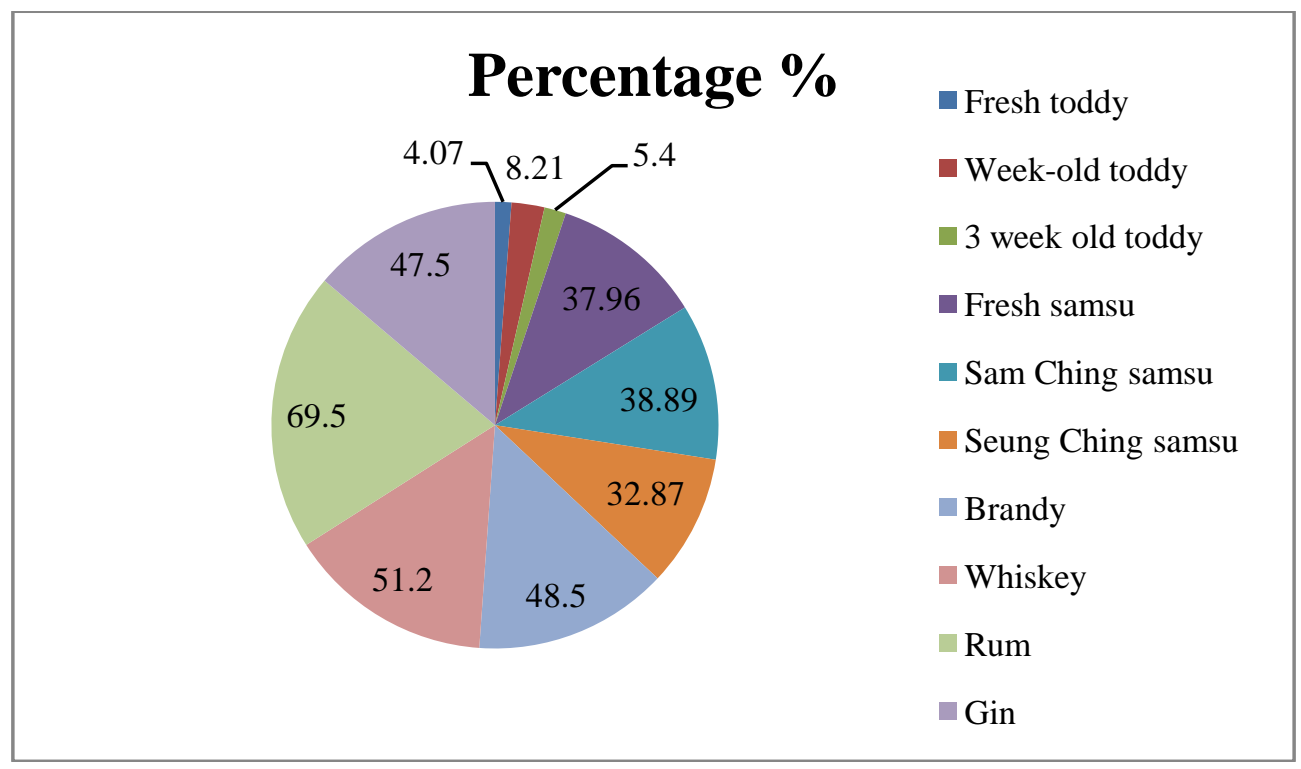

Source: Proceedings and Reports of the Commission, appointed to inquire into certain matters affecting the good government of the state of Selangor in relation to the alleged misuse and abuse of toddy in the coast district of Selangor - 1917, Kuala Lumpur: Federated Malay States Government Press, 1917, pp. 171 \& 172. 
One of the main reasons of toddy consumption among the Indian labourers was because they started drinking toddy at a young age, around 18 years and above. This development of the habit at an early age made it difficult for them to forsake it. This led to addiction among the Indians and grew so serious that the labourer could not work without the aid of the bottle. ${ }^{\text {xvi }}$ Other than the age aspect, the rate of toddy that a labourer drank should be taken into account to measure the level of toddy consumption by the Indian labourer. Usually, a labourer could drink around three to four pints of toddy daily. However, according to the rules, one should not drink more than one pint of toddy a day. ${ }^{\text {xvii }}$ In Province Wellesley (Straits Settlements) the monthly rate of toddy consumption among Indian labourers was recorded. There were 21 toddy shops in Province Wellesley. In November 1926, the toddy shops sold 18,897 gallon of toddy valued at $\$ 11,365$ to 5,740 adult male Indian labourers there. The Indian labourers there only received \$2 in monthly wage. The total revenue of the toddy shops clearly showed the rate of toddy consumption by Indian labourers. They spent most of their earnings on toddy. ${ }^{\text {xiii }}$ Apart from that, pure toddy is said to be sold at 15 cents per quart, mixed and artificial toddy ${ }^{x i x}$ at 10 cents per quart. The artificial toddy is alleged to be made from rice water, poppy seeds and white sugar. It is unable to trace any adulterant, the alcoholic strength was somewhat low and the extract high. Many coolies get intoxicated by mixing old and new toddy and that they obtain this mixture from the toddy shop at special request, the shop man keeping some a day or two for the purpose of mixing. The output of toddy does not meet the demand, hence artificial toddy is being largely made and makes the cooly drunk. ${ }^{\mathrm{x}}$

Table 1 Statement on some alcohol drinks consumed by estate labourers in Malaya

\begin{tabular}{|c|c|}
\hline Type of drink & tatement \\
\hline $\begin{array}{l}\text { Fresh toddy / } \\
\text { Unfermented toddy / } \\
\text { Nira / Nera / } \\
\text { Neera }^{\text {xxi }}\end{array}$ & $\begin{array}{l}\text {-Fresh toddy or Nira or in Tamil Pathany / Pathanir is sweet, unfermented toddy. } \\
\text {-Alcohol content in toddy is nil. } \\
\text {-Nira contains taste of lime and iron. } \\
\text {-Nira is non-alcoholic, rich in Vitamin B and Calcium. } \\
\text {-Nira has high level of nutrients compared to toddy and can function as milk-substitute in the } \\
\text { morning and toddy-substitute in the evening. } \\
\text {-If contains alcohol, is quite low, around } 4.07 \% \text { and safe to drink. }\end{array}$ \\
\hline Fermented Toddy ${ }^{\mathrm{xxi}}$ & $\begin{array}{l}\text {-Fermented toddy goes through fermentation process immediately after the sap is collected, in } \\
1-2 \text { hours. } \\
\text {-Fermented toddy contains } 8 \% \text { alcohol. } \\
\text {-After fermentation, toddy should be drunk in } 24-48 \text { hours. For the first } 36 \text { hours it is quite } \\
\text { harmless. After } 48 \text { hours, toddy contains } 4-5 \% \text { acetic acid and unsuitable for drink. After } 60 \\
\text { hours, the high level of acid in the toddy renders it dangerous for consumption. }\end{array}$ \\
\hline $\begin{array}{l}\text { Impure toddy } \\
\text { Mixed toddy }\end{array}$ & $\begin{array}{l}\text {-Impure toddy is the drink mixed with various ingredients, such as lime, alcohol, ganja and } \\
\text { datura to increase the alcohol content. } \\
\text {-This impure toddy will taste different, based on the ingredients used. } \\
\text {-Datura comes from the word Datura fastuosa which is "a native drug" / "a common way side } \\
\text { plant can produce a pleasant intoxication." The Datura is also used as a poison. Poisoning by } \\
\text { datura is common in India. The seeds are usually mixed with food or drink and the symptoms } \\
\text { which develop rapidly depend upon the dose, being generally those of a cerebral poison. }\end{array}$ \\
\hline$E r a^{\mathrm{xxiv}}$ & $\begin{array}{l}\text {-Era is made from Nira and "it is said to be medicated by means of some ingredients of } \\
\text { common daily use. This is said to invigorate and purify the blood." } \\
\text {-Not made in India, but in Ceylon. }\end{array}$ \\
\hline Samsu & $\begin{array}{l}\text {-Samsu is liquor made from fermented rice and the liquid. During the fermentation process, } \\
\text { yeast, water, banana, pineapple, and other ingredients are added. }{ }^{\mathrm{xxv}} \\
\text {-Samsu is more expensive and more dangerous compared to toddy }{ }^{\mathrm{xxvi}} \text { due to its high alcohol } \\
\text { content, around } 37.96 \% \text {. }\end{array}$ \\
\hline
\end{tabular}

In Malaya, toddy was, without doubt, not tapped on a large scale until after the immigration into this country of thousands of South Indian labourers from 1907 onwards. Prior to that date most of the Federation, as we know it to-day, was under forest. Before the last war there were slightly over 600 estate toddy shops in the territory, and just under 100 Government shops. An application for a licence for an estate toddy shop required the approval of the Controller of Labour before submission to the local licensing Board. The provisions of the Excise Enactment were enforced by officers of the Customs Department, who made frequent inspections of shops. ${ }^{\text {xviii }}$ 
Prior to the Japanese Occupation of Malaya the sale of spirits to Southern Indian labourers was prohibited and Government exercised a strict control over the collection and sale of toddy. In the Selangor districts of Klang, Kuala Selangor and Ulu Langat no toddy shops were permitted. ${ }^{x x i x}$ The end of 1941, the incidence of drunkenness amongst Southern Indian labourers had in a considerable measure been reduced and this process could have been expected to continue. ${ }^{\mathrm{xxx}}$

The position was completely changed during the Japanese Occupation when facilities for drinking toddy widespread and became popular with all classes of Indians and indeed with other races. The Japanese appear to have encouraged toddy drinking on the ground that it was of nutritional value. The number of urban shops multiplied and control over the supply of toddy on estates was inadequate. The Comptroller of Customs and Excise states that even now the demand for toddy is greater than in 1941. ${ }^{\text {xxi }}$ Japanese was encouraged the toddy drinking as long as it brought profit in some form or other. The number of Government and public shops increased to over 250 and it is believed that shops in rural districts increased very considerably but no figures are available. Toddy drinking which up to the occupation had been confined almost exclusively to South Indian labourers became popular with large numbers of other communities. ${ }^{\text {xxxii }}$

Estate toddy shops were closed in 1947 (after Japanese Occupation). At that time the labourers made no protest against the wise action of the Government in closing them. On the contrary the vast majority of the Indian labourers and the Indians in general were full of praise for the Government's action in stopping the supply of toddy almost at the very door of the Indian labourers. During this period of the closure of the Estate toddy shops the improvement in the physical condition and the economic and social status of the labourers has been quite noteworthy. The reopening of the toddy shops will, therefore be a retrogressive measure which will undo the good already achieved and will affect adversely the prosperity contentment and peaceful life of the Indian labourers. ${ }^{\text {xxiii }}$ Applications were made as early as $6^{\text {th }}$ October 1945 to re-open shops on estates but it was decided that for the time being, no toddy shops should be permitted on estates for the reason that only a few managers were available to administer very large estate areas and in consequence effective supervision of estate shops was not possible. Since then the number of managers and assistant managers in the country has been greatly strengthened but no estate toddy shops have yet been permitted. The present position is that the sale of toddy is authorized in urban areas and not on estates. Existing toddy shops are too far from most estates for labourers to make use of them but the evidence is that illicit sales to labourers of samsu and toddy are wide-spread. Drunkenness is reported to be common both in towns and estates and although it is difficult to asses its extent, estate managers report the position in this respect to be much worse than in 1941. The price of authorized toddy remains at 10 cents a pint but illicit samsu may cost $\$ 5$ a bottle and illicit toddy costs 25 cents a pint upwards. Samsu is now distilled from ragi, bananas and other materials and is likely to be even more harmful than the pre-war product. A proportion of labourers are reported to spend considerable sums on these liquors than they had done in the estate toddy shops. ${ }^{\text {xxiv }}$

Because of all these reasons, in 1949 government set up "The Estate Toddy Shops Committee", known as the Ross Committee, which made a Report (Ross Report) and recommendations. In effect, the Recommendations, whilst stating that government should make a public announcement of a policy aimed at reducing the use of alcohol by Indians and also, declare that considerations of revenue would not be permitted to stand in the way of decreasing the use of toddy or of completely abolishing it, permitted a toddy shop on an Estate under certain conditions, one of which was that there must be not less than 75 resident adult male South Indians and another that a ballot must be held of the whole labour force and a clear majority vote obtained. ${ }^{\mathrm{xxxv}}$

Finally, each State or Settlement Government in 1950 was allowed to decide whether it would permit the reopening or not of Estate toddy shops, subject to the adoption by the respective Governments of the recommendations of the Ross Committee. Most of the Governments concerned have exercised their option in favour of allowing the Estate Toddy Shops to re-open. ${ }^{\text {xxxvi }}$

Toddy shops have come to stay just as long as the Tamil labourers want them. The overall effects of the Ross Committee's recommendations have been to increase toddy drinking or, shall we say to increase open and legitimate toddy drinking. ${ }^{\text {xxxvii }}$

Nearly 30 to 50 per cent of the average labourer's earnings daily went on toddy; so if toddy drinking was stopped his domestic economy would improve. But it has not. The government also see among the Indian estate labourers an increase of beri-beri, an increase of diarrhoea, dysentery and liver abscess. 
Furthermore, some Indian labourers in various stages of acute intoxication. That is because they drink fermented toddy on an empty stomach, or they drink bad toddy with very poor food, with the result that the intoxication gets more acute than in the case of the Chinese labourer for example, who has good food and takes samsu and does not get intoxicated to the same extent. There is everything to recommend the re-opening of estate toddy shops. It is moot point to say that toddy is an evil; but if it is an evil it is certainly a lesser one than illicit samsu. Good toddy is better than bad samsu, irrespective of price or other considerations. ${ }^{\text {xxxviii }}$

However it is acknowledged fact that toddy is the worst man-made evil that is plaguing the life of the poor Indian labourer on the estate. Though the Indian community has been fighting hard to get rid of it, it only continues to thrive because the owners of the rubber industry have found in the toddy evil a powerful weapon to kill the soul of the labourer, while for the Government it serves as a ready source of considerable revenue. The toddy evil, however, is not restricted to estate labourer only, but it adversely affects Indian labour as a whole, as well as the poorer sections of the other communities. ${ }^{\text {xxxix }}$

After Malaya was liberated, all shops other than Government shops which had been established before the war were closed, but there was a large illicit traffic in the countryside in inferior liquor with consequent deleterious effect upon the health of the rural labourers. ${ }^{\mathrm{xl}}$

The toddy issue persisted even after independence. Nevertheless, compared to other alcoholic beverages, toddy contributed least in the alcoholism problem in post-independent Malaysia. ${ }^{\text {xli }}$ Indians are the largest group of drinkers in the country. A Consumer Association of Penang (CAP) estimate stated there are around 200,000 alcoholics in Malaysia, and from this number, 130,000 are Indians, 50,000 are Chinese, and 20,000 are Malays. ${ }^{\text {xlii }}$ According to a report released by the NUPW (National Union of Plantation Workers) as published in the New Straits Times, an estimated $25 \%$ of Indians in estates are alcoholics. ${ }^{x \text { liii }}$ The statistics mean Indians are still involved in toddy-drinking post-independence, but in a far smaller scale. Instead, they turn to other alcoholic beverages such as beer (5\% alcohol), wine (12\% alcohol), whiskey, brandy, and rum (40-43\% alcohol), ${ }^{\text {xliv }}$ due to the scarcity of toddy shops and access to liquor with higher alcohol content than toddy. In addition, the growing source of income meant anyone could enjoy alcohol. From the explanation, it could be surmised that Indian estate labourers in the colonial era were stuck with the image of drunkard or toddy drinker. However, after independence, this image was somewhat shed as people of various ethnic backgrounds partook in this habit.

\section{Malayan Government and India Government policy towards toddy}

There is a sharp cleavage of opinion on the subject of toddy drinking by estate labourers in this country. Indian opinion both official and private, in this country as well as in India, sees nothing but evil in it and wants it abolished. It is argued that in India, toddy shops exist only in towns and before coming to this country, the ordinary estate labourer had never even tasted toddy. Total prohibition for the whole Madras Presidency is the politician's objective, and it is not desired that the toddy habit should be brought back by addicts returning from overseas. Estate labourers in Malaya suffer both in health and in pocket by squandering on toddy, money which ought to be saved or spent on nourishing food. The Malayan Government is suspected of being influenced in its toddy policy by the revenue aspect. ${ }^{\text {xlv }}$

The planter's view is that pure toddy is a refreshing beverage of low alcoholic content and its provision is not only a pleasant amenity but is also beneficial to health on account of the Vitamin B content. Tamil labourers in this country need toddy unless it is provided on the estate, they will go elsewhere in search of it or more harmful drinks, with consequent damage to their health and their pockets. Old adulterated toddy is admittedly bad for the labourer but before the war, estate toddy shops under European supervision and provided a supply of fresh wholesome toddy at low cost. The truth appears to be that a daily glass of fresh toddy is beneficial to the health and is in fact prescribed for certain kinds of vitamin deficiency. It is however a fact that most estate labourers taste toddy for the first time when they come to Malaya and spent on nourishing food which would provide the necessary vitamins and stamina to resist diseases.

At 10 cents a glass, even one glass a day was an extravagance for a Tamil labourer and for many, one glass by no means sufficed. Admittedly, there are now a number of toddy habitués who crave for it and its absence will resort to any form of alcohol no matter how harmful. ${ }^{\text {xlvi }}$

Before the war, there were three districts, Klang, Kuala Selangor and Ulu Langat, where toddy shops were prohibited and the resultant reduction in crime make the police oppose the re-introduction of toddy shops. Whilst the Customs Department and the planters still allege that in these districts, illicit samsu was consumed by Tamils, 
it is doubtful if any responsible person would favour a restoration of the old position. Further, experience in these districts suggest that no toddy policy could be extended to the rest of the country, without obvious disadvantages of a serious nature. ${ }^{\text {xlvii }}$

In considering future Tamil policy, it is to be remembered that the Malayan Government are committed to doing what they can to decrease the consumption of alcohol by Indians. Indian sentiment on this matter is very strong and should negotiable be resumed for the re-opening emigration from India of unskilled labour, it would be a point in our favour that the Malayan Government have made progress in reducing toddy drinking. This was the general policy of Malayan Government in pre-war years. Further, for the Malayan Government, estate toddy shops were an important factor in maintaining discipline and health among the labour force, and when a drink of wholesome toddy was not available on or near the estate, labourers would frequently obtain some injurious alcohol or wander some distance from his own estate to obtain toddy. ${ }^{\text {xliii }}$

However, the policy of the Government of India towards toddy has hardened considerably since those days. In his despatch to the Colonial Secretary, Singapore dated 28.3.1939, the Secretary to the Government of India stated the Indian Government's policy on toddy as follows:

"The India Government are aiming at total prohibition and naturally do not want labourers from the Presidency to acquire the drink habit in other countries and bring the habit back with them to Madras. Them do not wish to force their ideas upon any other Government, all them ask for is as much assistance as possible. The practical suggestion is that toddy shops on estates should be closed and Government toddy and liquor shops sited as far as possible from places where Indian labour is employed. It may be noted that there are no liquor shops at all in the Anamalais, while in the Nilgiris and the Wynis there are no toddy shops and arrack shops on estates. It is realised that in Malaya the population is heterogeneous and estates adjoining each other closely the sitting of a shop a suitable distance may be a matter of some practical difficulties. It is felt however that at least a beginning might be made where there is a large concentration on Indian labour, unmixed for most part with labour of other races." "xlix

Further, the Salem district in Southern India used to be perhaps the toddy-drinking district in the Presidency with more toddy shops per head of population than existed anywhere else. About 7 years ago Mr. C. Rajagopalachariar the Prime Minister of Madras, closed down toddy in the district completely. There is a parallel in this country where for a number of years now the three Districts of Klang, Kuala Selangor and Ulu Langat at Selangor have been "dry". During this time the vast majority of Indian labourers is these districts were opposed to any reopening of toddy shops. This is the only test case we have in Malaya. The 1936 Annual Report records a case in point, "...on a certain estate where the toddy shop was recently closed and the number of toddy drinkers fell from $90 \%$ to $30 \%$ of the adult male population."

A further point that is urged in favour of toddy is its Vitamin B content. That was a perfectly sound point in normal times when the labourer earned money to ensure first of all that he and his family were well nourished and clothed. That is not possible and there is no benefit he gains from toddy that he could not better secure by the purchase of other things and what happens to his wife and children if he is encouraged to spend a considerable proportion of his income on Vitamin B for himself? In all the departments' investigations over many years it was found that the wives and mothers were solidly opposed to toddy- a very significant fact. The revenue arguments cannot be considered. The 1938 Annual Report states,

"The Governments of Malaya have declared that revenue considerations will not stand in the way of decreasing the use of toddy or abolishing it entirely.",li

But in 1940, the amount of revenue derived from toddy in the Federated Malay States (Perak, Selangor, Pahang, Negeri Sembilan) alone amounted $\$ 1,355,569$ of which $\$ 603,730$ was from estate toddy shops. Out of all the controversy that has taken place on this question in previous years the Malayan Governments have arrived at one clear policy.

That is stated earlier, that they "will continue to do what they can to decrease the consumption of alcohol by Indians." Out of all this controversy there has been recognised by the Malayan Governments, the planting interests and everyone else concerned. It is that the real stumbling block to the abolition of toddy has been Chinese distilled rice samsu. Even the Sastri commission reported:

"The weight of evidence regarding the widespread illicit distillation of samsu is so great that it is impossible to disregard it."lii 


\section{What is Toddy?}

According to "The Encyclopedia Americana", toddy or palm wine is a drink made in tropical countries from the sap of various palms, especially when in a fermented state. The word is of Hindustani origin and is generally applied in India to the substance used as yeast to leaven bread. In the Malayan Archipelago, toddy is the sweet juice of the flower sheaths of "Arenga Saccharifera". The Malay name for the toddy tree is enau, kabong or berkat. ${ }^{\text {liii }}$ Toddy is a sugary juice from a coconut tree. It requires no processing and can be drunk as soon as it is drawn from the tree. ${ }^{\text {liv }}$ Pure fresh toddy is wholesome to drink. It contains little alcohol, has vitamin B2 properties, and it is not injurious to health when taken in moderate quantities. However, it should be consumed within 12 hours from the time it is drawn. When it is 48 hours old, it has more alcoholic and acidic content. ${ }^{\text {lv }}$ For this reason, to ensure a supply of fresh toddy, the Customs Department has made it a legal obligation on all toddy shops to throw away each morning unconsumed toddy left from the previous day. Besides being the favourite drink of the South Indians, toddy has other uses. It is use in the manufacture of sugar. If it is left to ferment it can be converted into acetic acid for coagulation of rubber latex. It is said that toddy can be used to cure chickenpox and smallpox. Nowadays some qualified medical practitioners prescribe toddy for sufferers from pile or from sprue. $^{\text {lvi }}$

Toddy is white in colour and is quite thick and looks like barley water, but it has got a strong odour which is sweet smelling to the toddy drinker but repulsive to the others. It is supposed to give a sweet-sour taste. Most like to take it very strongly fermented. The more fermented it is, the stronger is the alcohol and the 'kick'. Generally, toddy has a very low percentage of alcohol content but just like excess of anything is injurious; excess of toddy can get you drunk. Toddy has always been the typical drink of Indians particularly of the labour class. ${ }^{\text {lvii }}$

Basically, the source of the drink collected from the coconut tree is known as the nira, as it has yet to undergo the fermentation process and has no or, if any, very low alcohol content. lviii Nira means a drink freshly taken from the tree and is still unfermented, and this fresh state remains for 12 hours. If consumed within this time period, it is not harmful to health and not intoxicating. ${ }^{\text {lix }}$ After the nira undergoes fermentation, it is known as toddy. This process is very rapid, due to the presence of natural yeast. Fermentation occurs immediately after collection of nira, around one or two hours, and this process continues until the alcohol content increases to $10 \%$. $^{\mathrm{lx}}$

\section{Pure Toddy}

On a basic level, fresh or undoctored toddy contains low level of alcohol ${ }^{\text {lxi }}$ Undoctored toddy, up to about 36 hours, is a most harmless drink. Toddy, however long kept, never gets more alcoholic than mild claret (though it turns acid) and it would really be easier to get drunk than on undoctored toddy not more than 36 hours old. The palm juice in itself contains neither acidity nor alcohol, but begins to ferment as soon as it gets into the collecting pot on the spathe. Including the 12 hours in the pot on the spathe both acidity and alcohol increase for about 48 to 60 hours; after that the alcohol begins to be converted to acidity and the alcoholic content rapidly decreases while the acidity rapidly increases. If undoctored, toddy could never exceed the legal alcoholic limit of 10 per cent., but any time after 48 hours it may exceed the legal limit acidity 0.8 per cent. For the first 36 hours it is a harmless and pleasant drink, for the next 24 hours it is still harmless but stronger, after 60 hours it is, if undoctored too acidic for human consumption. ${ }^{\text {lxii }}$ In plain words, a very acid toddy may produce an indigestion and a diarrhoea. Further more, the symptoms of toddy-poisoning generally seen are as follows: The patient is in a state of profound collapse, the temperature sub-normal, the skin covered by a cold, clammy perception, and the pulse soft and rapid, may be uncountable or completely absent. There is persistent vomiting, acute diarrhoea, and partial or complete suppression of urine. The symptoms come on within a few hours of drinking the toddy, the death frequently occurs within 36 hours. ${ }^{\text {lxiii }}$

\section{Adulteration}

Unfortunately the adulteration of toddy is easy, and its detection difficult.

Fresh toddy mixed with 60 hours old toddy is similarly 60 hours old toddy with the addition of a little sugar and perhaps a little alcohol is in distinguishable from 40 hours old toddy. But both mixtures ferment very rapidly, and in a very few hours the alcohol in gone, the acidity is above the legal limit and the coolie suffers. The lime, Datura and various other substances are also used for adulteration with even more injurious results. This adulterated toddy will taste different, based on the ingredients used. The addition if skilfully done, would not be detectable. ${ }^{\text {xiv }}$ 


\section{Question of terminology}

Some terms in this article should be explained. Among the more important terms are fresh or pure or undoctored toddy, and impure or old or doctored toddy. These terms were consulted and taken from archival sources. Fresh toddy / Unfermented toddy / Undoctored toddy means toddy that did not undergo the fermentation process, or free from foreign substances. For the Malays, pure or fresh toddy refers to the nira. Nira has high level of nutrients compared to toddy and can function as milk-substitute in the morning and toddy-substitute in the evening. Nira is non-alcoholic, rich in Vitamin B and Calcium. ${ }^{1 x v}$ Doctored toddy / Fermented Toddy go through fermentation process immediately after the sap is collected, in 1-2 hours. ${ }^{\text {lxvi }}$ Meanwhile, adulterated toddy / Impure toddy is the drink mixed with various ingredients, such as water, sugar, formalin, lime, alcohol, ganja and datura to increase the alcohol content. Datura comes from the word datura fastuosa which is "a native drug" / "a common way side plant can produce a pleasant intoxication." "xvii Samsu is a liquor made from fermented rice and the liquid. During the fermentation process, yeast, water, banana, pineapple, and other ingredients are added. ${ }^{\text {lxviii }}$ Samsu is more expensive and more dangerous compared to toddy ${ }^{\text {lxix }}$ due to its high alcohol content, around $37.96 \%$. ${ }^{\mathrm{lxx}}$ Illicit Toddy means toddy sold without license and without government knowledge.

\section{Food-stuffs near Toddy Shops}

It is admittedly not good for the coolie to drink on an empty stomach and, therefore, the sale of cakes and sweetmeats near a toddy shop should be encouraged. On the other hand the sale of curry or of any hot and thirst producing food stuffs should be prohibited by law. Tainted prawns, crabs, etc., are frequently used for curry and the taint disguised by their being curried, while the objections to thirst producing food-stuffs are obvious. These will, however, always be available at no great distance from the shop where the lessee's prime interest is to sell all the toddy he can. lxi $^{\text {. }}$

\section{Toddy Tapping Industry}

Not much is known of toddy before the arrival of Indian labourers, and toddy sale activity was almost unheard of. The Malays, for example, used coconut juice (nira) as a beverage and also as ingredient in 'gula melaka' (palm sugar). However, following the arrival of the Indians in Malaya, a new phenomenon emerged with the widespread consumption of toddy and the expansion of the toddy business. Based on this situation, it would not be an exaggeration to state that the rapid development of toddy retail is in tandem with the arrival of Indian labourers in Malaya. The development of this industry could be seen in the Annual Report of the Agent of the Government of India in British Malaya, 1928.

"The habit of toddy drinking amongst Indian labourers in this country is increasing year by year. Even abstainers and occasional drinkers in India become confirmed daily drinkers after their arrival here and freely indulge in it. In some places women and children are also reported to get addicted to it. The establishment of toddy shops close to the labourers' lines on the estates, and the location of two or more shops at close distances, are apt to increase the evil rather than diminish it. The evil of toddy drinking is rampant, and goes on unchecked."

\section{The Coconut Tree}

Generally, the coconut tree begins to bear fruit when it is about 5 years old. Tapping of the tree for toddy, however cannot be done until it is 7 years old. It does not bear fruit whilst it is in tapping. The average height of a tree in tapping is 35 to 40 feet. ${ }^{\text {lxxiii }}$ Toddy is actually obtained from a spa the of the tree. ${ }^{\text {lxiv }}$ The average tree bears a spa the of about $2 \frac{1 / 2}{2}$ to 3 feet long at intervals of about a month and produces about 10 to 12 spathes in a year. ${ }^{1 \times x v}$ Toddy can be drawn from one spathe for approximately one month. The average tree sometimes requires rest for period of one or two months in a year depending on its age and physical condition. Generally, it is tapped twice a day, once in the morning and once in the afternoon. Its average yield is about 3 to 4 pints per day; about two thirds of quantity is obtained from the morning tapping and one third from the afternoon tapping. As the tree grows older, its yield decreases, and finally ceases after the tree has been tapped for 15 to 18 years. ${ }^{\text {lxvi }}$

Not all trees are tapped and tappers themselves are experts at selecting good trees. ${ }^{\text {lxxvii }}$ Climate conditions affect the yield. The ideal weather is neither too hot nor too wet. On a very dry day the yield decreases. On a wet, rainy day the yield is watery and loses some of its taste, and in consequence its sale for the day is poor. The lean period for the toddy tapping is during the dry season when the yield falls by about $10 \%$. Hot weather and the difficulty caused to the tapper by his exposure to to the danger from hornets swarming on the spathes are the principal causes for the fall in the yield. 
It appears that there is some slight variation in climate conditions in the different part of Malaya. In Selangor the dry season begins from about July or August and lasts for about 3 to 4 months. Rents ranging from 80 cents to $\$ 2$ per tree per month are paid by toddy tapping contractors to tree owners depending on the demand for trees and where the trees are required. In Selangor the usual rent is $\$ 1.20$ per tree while in Penang and Province Wellesley the rents vary from 80 cents to $\$ 1.00$ per tree. In Kedah the rent is $\$ 1$. $^{\text {lxxiii }}$

\section{Workers in the Industry}

During the colonial period, the toddy industry provided a wide range of employment opportunities for the Indian labourer.

\section{The Toddy Tapper}

The tappers are mainly Southern Indians of the Nadar caste. They are tappers by caste, this is the only work they know. In Kedah, however, a number of Malayalees are employed. Indians of the Nadar caste have a well established reputation as being clever climbers; employers in the industry generally prefer to employ them. It is said that the finer art of tapping is seldom taught to local Indians of other castes. There is no shortage of tappers in Malaya. In Negeri Sembilan there is large number of Indians whose pre-war occupation was toddy tapping. They are now employed in other industries but it is said that they would be very willing to return their former occupation should there be a demand for more toddy tappers. ${ }^{\text {lxxix }}$

It is a skilled job and a man cannot come from another occupation straightaway become a tapper. ${ }^{\text {lxx }}$ Most of them are wedded to toddy and drink as much as $3 / 4$ gallon each day. The contractors admits that the tappers take as much as 5 to 6 pints daily during their tapping; in fact it is more in the nature of a ration and that the tappers are free to take the liquor away with them. This is not largesse from a benevolent contractor, but is done simply because he fears that if he doesn't give them the toddy or allow them to take it, they will either refuse to work or start to tap illicitly. ${ }^{\text {lxxi }}$

There is no training centre in Malaya for toddy tappers. If a person wishes to become a toddy tapper, he makes arrangements with a skilled tapper to teach him the art of climbing and tapping a coconut tree. It is said that it takes a person about 6 months to acquire sufficient skill and confidence in climbing and tapping. Generally speaking, a toddy tapper begins as an apprentice at the age of about 19 and retires from the occupation when he reaches 50 or so, but there are a few tappers in Malaya who are still employed on this arduous work though they

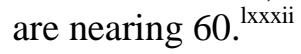

Regarding the wage rate, three methods are in use to pay the tappers for work done, namely on monthly rate, daily rate or piece-rate basis. Tappers employed directly by the Customs Department, for instance in Johore are daily rated workers but there are also a few on monthly rates. Tappers employed directly by estates are either daily-rate or piece-rate workers while those in the employ of toddy contractors are generally piece-rates workers and they form the majority of tappers in the industry. The rates paid by toddy contractors to tappers vary slightly in certain places. The usual rate is 50 to 55 cents per gallon. ${ }^{\text {lxxiii }}$

At the work place, for greater freedom of movement of his limbs all that the tapper wears whilst is a pair of short pants. He has a self-made container (in Tamil "Chatti") tied to his waist by means of a leather belt. ${ }^{\text {lxxiv }}$ Hanging from the belt is an empty gourd. In the container are kept his implements, namely a curved tapping knife, a pruning knife, some rattan strips and a wooden mallet. In addition, he has a long piece of wood on which is sprayed stone powder for sharpening knives. ${ }^{\text {lxxv }}$ If steps on the trunks of his trees are not cut he uses a climbing twine and slings it round both his feet to aid him in his climb. Nowadays, however, the climbing twine is seldom used as steps are normally cut on the tree trunks. Besides his implements he also carries in his hand a large earthen pot. ${ }^{\text {lxxxvi }}$

\section{The Toddy Carrier}

It is usually the tapper's duty to bring his toddy to the collecting centre to be measured either by his employer, i.e. the toddy contractor or by the employer's clerk. The tapper keeps a tally card in which is recorded either by the employer or the clerk the quantity of toddy he has brought in each day. When toddy from all the tappers has been brought in and is taken away by a van or lorry to the toddy shop for which it is intended, there to be sold to customers. If the collecting centre is far away from the tapping area and if the employer has a good number of tappers, one or two labourers are employed as toddy carriers whose duty is to carry all the toddy in the field to the collecting centre and do all the necessary handling of toddy until it reaches the toddy shop. ${ }^{\text {lxxvii }}$ 


\section{Step Cutters}

At the beginning of each year when tenders for toddy supply are approved, there is a great demand for step cutters. Where a tree has not been tapped before, steps must be cut on its trunk to enable the tapper to climb the tree for processing. Not all toddy tappers can cut steps on the trunks of trees. Steps are cut at intervals of $2 \frac{1 / 2}{2}$ to 3 feet apart. The usual rate for step-cutting is $\$ 1$ per tree and the steps are renewed once a year at the rate of 80 cents per tree. ${ }^{\text {lxxxviii }}$

\section{Clerks}

Only big toddy contractors, employing say about 15 tappers or so and having more than one tapping area engage proper clerks to assist them in the supervision of tapping, collection of toddy and the keeping of accounts relating to the tappers' work, earnings and payment of wages. Small contractors generally supervise the tappers themselves and undertake the keeping of accounts. Some of them arrange for a relative or a tapper, whom they can trust, to assist them and pay $\$ 20$ to $\$ 30$ per month for the assistance given. ${ }^{\text {1xxix }}$

\section{Lorry or van drivers}

Only big contractors with large contracts to fulfil employ drivers who are paid from $\$ 120$ to $\$ 150$ per month. Small contractors arrange with lorry owners for the conveyance of their toddy to toddy shops and pay various rates for the use of the lorry according to the distance travelled each day. ${ }^{\mathrm{xc}}$

\section{Conditions of Service}

The occupation of a toddy tapper, besides being arduous, is not free from danger. He may fall or be attacked by hornets. ${ }^{\text {xci }} \mathrm{A}$ piece-rate tapper suffers a loss in earnings during the hornet season. In about August to September every year hornets come to coconut trees, swarm round the spathes and start to build nests. When the tapper reaches the top of a tree he often finds numerous hornets on the spathes or in the pots. He runs the risk of attack by these hornets and sometimes he gets stung all over his body. If he is an inexperienced worker or if he is stung very badly, he may lose his balance and fall. Because of his fear of the hornets he is unable to tap the spathes properly and in consequence the yield drops and he suffers loss in his earnings. ${ }^{\text {xcii }}$

Unlike workers in other industries, the tapper is expected to work daily so that his employer, the contractor, can supply each day the quantity of toddy required. The Customs Department has provisions to penalise the contractor for any shortage of supply. To keep his job, every tapper therefore endeavours to work every day, and in fact he works an average of 29 to 30 days in a month. A piece-rate tapper generally does not like another tapper to tap his trees during his absence, for fear of possible damage done by his substitute to the spathes. A tapper's hours of work are divided into two periods, once in the morning and once in the afternoon. He works generally 6 to 7 hours a day, but tappers in Kelantan and Terengganu work only $4 \frac{1 / 2}{2}$ hours. ${ }^{\text {xiii }}$

\section{Toddy Contractors}

Toddy tappers are either employed direct by the Customs Department, by Estate or by contractors. By far the greatest number is employed by Contractors. These contractors are mostly South Indians and include a few Chettiars. In Selangor, however, many of the contractors are Ceylonese Tamils. The number of tappers employed by a contractor depends on how many contracts he has in hand and the quantity of toddy he has undertaken to supply. One Chettiar contractor in Penang employs as many as 53 tappers while there are contractors who employ as few as one or two tappers each. ${ }^{\text {xciv }}$ In almost all cases proper accounts relating to the work and earnings of the workers are kept by contractors. The keeping and maintenance of proper accounts is one of the requirements of the Customs Department. Cash advances are given whenever required and wages are settled on or about $7^{\text {th }}$ of the following month. ${ }^{\text {xcv }}$

\section{How Toddy is Tapped?}

In the tapping area the trees allocated for tapping are marked with numbers. ${ }^{\text {xcvi }}$ When toddy tapper gets to the tree which he is going to tap, he places the earthen pot at the foot of the tree and starts climbing the tree.

On reaching the tree top, he stretches out his hands for the earthen pots into his empty gourd. He then shaves off a bit of the spathes. Than he comes down and on reaching the ground, he pours the toddy from his gourd into the large earthen pot at the foot of the tree. He picks up the large earthen pot again and places it at the foot of another tree. Thus, he climbs and taps tree after tree until he has tapped his entire task. It is reckoned that the process of his work takes approximately 6 minutes per tree. In the case of a tree that has not been tapped before, he rids the tree of all decayed vegetation and throws down, if any, all the coconuts. ${ }^{\text {xcvii }}$ He chooses a good spathe that is 
between 3 to 4 weeks old, binds it with split rattan at intervals of about an inch, and pares the top of the spathe. For the next three days, every morning he climbs the tree and beats the spathe lightly all over with his mallet and pares the top. Commencing from the fourth till the tenth day he repeats this process of work once in the morning and once in the afternoon. On the eleventh day, he rams lightly the top of the spathe with a wooden stick till toddy begins to drip. The top is then pared off and an earthen pot is hung on the spathe to hold the toddy. The average spathe yields toddy for about a month or so. From now on he climbs the tree every morning and every afternoon, pours the toddy, that has dripped into the earthen pot, into the empty gourd tied to his waist; if necessary he beats the spathe lightly all round, pares the top of the spathe and puts back the pot on the spathe to hold the dripping toddy. ${ }^{\text {cviii }}$

The average tree produces a spathe at intervals of about a month and about 10 to 12 spathe in a year. As toddy is being drawn from one spathe, the tapper prepares in the manner as described above a new spathe that has sprouted; thus there is a constant source of toddy from the tree. Though a spathe normally yields toddy for about a month or so, the duration of its yield depends on how the spathe has been prepared for toddy extraction and it is pared daily. To the employer and the tapper the more the spathe yields the better. From a task of 25 reasonably good trees a good tapper should obtain 10 to 12 gallons of toddy per day. While a less skilled or bad tapper is likely to obtain less, a daily yield of 6 to 7 gallons from a task would be regarded with suspicion as pointing to illicit sales. A good tapper generally has at least two yielding spathes in a tree. ${ }^{\text {xix }}$

\section{Toddy from the Tapping Area to the Cup of the Consumer}

Toddy retail is dependent on supply to toddy shops in Malaya. ${ }^{c}$ Once the toddy has been tapped in the tapping area, the contractor assistant measures the amount of toddy tapped by each toddy tapper and pours them into buckets or large containers. Then he transfers the toddy into a truck or van owned by the contractor. The particular vehicle has to be registered and on it is written boldly the name of the contractor, the purpose for which the vehicle is to be used and the number of workers permitted to travel in the vehicle. The toddy is then distributed to the shops to which the contractor is only allowed to tap the amount of toddy for which he holds the tender. Toddy contractors supply toddy to Government, Estate and Public toddy shops. ${ }^{\text {ii }}$ However, it is obvious that toddy contractors also supply illicit toddy to illegal or unlicensed shops. Government, Estate and Public toddy shops have stipulated times during which toddy is on sale, whereas in illegal toddy shops, toddy is on sale the whole day. As for the rates at which the toddy contractors charge the respective toddy shops and retail price of the retailers, they will be dealt with in a later chapter. At the Government, Estate and Public toddy shops there are limitations are side-lined. In an illegal toddy shop, toddy is supplied until the man is dead drunk. No credit is allowed in Estate, Government and Public toddy shops, but illegal toddy shops do provide credit facilities to regular and 'trust worthy' clients. ${ }^{\text {cii }}$

Demand of toddy was also influenced by the weather, as demand for toddy increased during the hot weather. This occurred as toddy was considered to have cooling properties. In addition, demand for toddy also increased on Sundays, festivals, and public holidays. ${ }^{\text {iii }}$

Toddy were the social evils for which the responsibility is not the affair of those directly concerned, but, the responsibility of the whole community. The lot of the Indian labourer will indeed be the direct concern of all the communities in near future, as, with the decline in immigration of Indians, Chinese and Malays will be doing much of the estate work which has traditionally been done by Indian labour. The conditions of that labour will directly influence the behaviour and morale of these communities and the presence of toddy shops on estates, with the cheapness of the drink, will be a real temptation to the Indians there.

The condition of an Indian labourers family whom drink has brought into complete neglect of home, children and home-life where indeed the very children fall into the drink habit at an age when they have no responsibility whatever cannot but deplore that proposal. Unfortunately, toddy drinking is a vice, and no responsible person can, we feel, encourage government consent, which in the circumstances will mean government support for it. ${ }^{\text {civ }}$

\section{Sale of Toddy}

There are three kind of toddy shops authorized to sell toddy by retail, for consumption on the premises only. ${ }^{c v}$ Namely estate toddy shop, government toddy shop and private toddy shop. Of these three shops, the estate toddy shops were found to be in many estates owing to the influx of Indians working in a various estates in Malaya. Majority of the labourers who consume these toddy normally the people who does tough jobs like a rubber tapping, road works, drainage, coconut climbing, grass cutting and so on. As a result of heavy consumption of this 
toddy, the labourers heavily addicted and dependent on the liquor for their survival especially for health strength and vitality. Thus, loosing their sole income on these drink thereby neglecting their family and torturing their wife and children, not giving them proper education and well being. By doing so, the British government and the toddy shop operators have made huge profits and the Indians had to suffer in pain.

\section{Government Toddy Shop}

Government toddy shops owned and managed by the State or Settlement Government. In many cases toddy is supplied and delivered to the shop by a licensed toddy tapping contractor at an agreed rate per gallon. Usually it is delivered twice a day. Rates paid by Government to toddy suppliers vary slightly from place to place. In Perak the rate per gallon is \$1.10, Penang and Kedah \$1.00, Negeri Sembilan 90 cents and in Selangor \$1.05. In North and Central Johore the Customs Department employs tappers direct to obtain toddy for the shops there. Large shops generally have a manager, one or two salesman and a watchman while small shops have only a clerk or salesman in charge and a watchman. They are all Government employees. These shops are in in town and are open generally from 10 a.m. to 7 p.m. daily. All net profits go to the State / Settlement Government as revenue. There are no shops in Pahang and Perlis. ${ }^{\text {cvi }}$

\section{Estate Toddy Shops}

The second type of toddy shop was the estate or plantation toddy shop. The shop is licensed in the name of the estate manager and was managed by estate managers or employers. ${ }^{\text {cvii }}$ Some estates employ tappers direct and pay them either on a daily-rate or piece-rate basis, while other estates arrange with licensed toddy tapping contractors for the supply of toddy an agreed rate per gallon. The estate toddy shop is opened from 3 p.m. to 6 p.m.or from 4 p.m. to 7 p.m. The Customs Department limits the supply of toddy to the shop to ensure that there is no excessive drinking. This was because the Indian labourers in the estate were the majority consumers in the colonial period. $40 \%$ of the gross takings go to the State or Settlement Government as revenue and all the net profits was used for the benefit and welfare of the Indian labourers. ${ }^{\text {cviii }}$

\section{Public Toddy Shops}

Public toddy shops were managed by successful tenderers under government supervision. This shop is run on terms agreed upon between Government and the successful tenderer ${ }^{\text {cix }}$ and hours for the sale of toddy are the same as those of a Government toddy shop. $40 \%$ of the gross takings are taken by the Customs Department. There are 3 such shops in Trengganu and toddy there is perhaps the cheapest. If he wants, a toddy shop salesman can make something extra in addition to his pay. The usual trick is to pour the toddy from a height so that there is plenty of froth and thus, the customer is about $1 / 2$ inch in short supply in his pint mug. ${ }^{\mathrm{cx}}$

\section{Control of Toddy: Licence and Tender}

Realising the importance of toddy in the lives of estate communities, as well as the potential profit from this activity, the British allowed for the establishment of the toddy business in towns and estates through a tender and licence system. ${ }^{\text {cxi }}$ The government set regulations that any toddy shop should obtain tender and licence before starting their toddy business.

In every State or Settlement the Customs Department is in absolute control of toddy. Each year the Customs Department calls for tenders for the supply of fresh toddy for toddy shops. ${ }^{\text {cxii }}$ For example, in Penang and Province Wellesley tenders are called for in September each year for the supply of toddy for the following year. The tenders are received and considered by a Toddy Tenders Board which submits the selected tenders together with the Board's recommendations to the Resident Commissioner, Penang for approval.

Persons whose tenders have had the Resident Commissioner's approval then submit their application to the Licensing Board, and when approval has been obtained the Customs Department issues licence to the applicants. In Perak, however, tenders are for two years. Perak has found that this two-year period is more satisfactory in that it gives contractors greater security of tenure. ${ }^{\text {cxii }}$

While applying for tender, tenders must be sealed and marked on the outside "Toddy-shop Tenders or Toddyshop application". Tenders form can be obtained from the District Offices. The Government does not bind itself to accept the highest or any tender. Each tender must be accompanied by a Treasury deposit receipt or bank draft for $\$ 50 / \$ 100 / \$ 200^{\text {cxiv }}$ on the name of the Resident in their respective States. Otherwise it will not be considered. If any tender withdraws his offer after his tender has been accepted by the Chairman, his deposit will be forfeited to the State. The deposits of unsuccessful tenderers will be returned. For each locality there should be a separate 
application and a single application for several localities will not be considered. The fee imposed by the rules concerning toddy-shops of $\$ 1.50$ for every month or part of a month in respect of each licence must be paid monthly in advance to the District Officer. The successful applicants will be entitled to the issue of a toddy shop licence to himself or to such person nominated by him as the Licensing Board may approve and for such house, shop or other place only as the Licensing Board may approve. A successful applicant will make his own arrangements with the owners of the coconut trees from which the toddy is drawn and with any holder on whose land the house, shop or other place approved for a toddy shop may be situated. ${ }^{\mathrm{cx}}$

Any estate manager wishing to open a toddy shop on his estate has to produce evidence to show that is a real need for a toddy shop on his estate. Firstly, his request must be supported by a permit from the Deputy Commissioner For Labour for the State or Settlement; and to obtain this permit, which is only given after careful scrutiny, he must satisfy the Deputy Commissioner for Labour that there are at least 75 South Indian adult male labourers employed on his estate, and that a majority of the labourers want a toddy shop. If a permit is issued to the Manager by the Deputy Commissioner for labour on behalf of the Commissioner for Labour, he applies in the usual way to the chairman of the Local Licensing Board for a toddy shop licence, forwarding the permit from the Labour Department. The permit, however, is no guarantee that a licence will be issued to him. The board may grant or refuse a licence, even when a permit has been obtained. The position is that no Licensing Board will issue a licence in the absence of a permit from the Labour Department. When a licence has been issued to him, the manager can then start a toddy shop on his estate. He may employ toddy tappers directly. If he gets a toddy contractor to supply his estate, that contractor must have a licence from the Customs Department. ${ }^{\text {cxvi }}$

A licensed toddy tapping contractor has to comply with many requirements of the Customs Department and any failure to fulfil any of the requirements may results in cancellation of his licence. ${ }^{\text {cxvii }}$ He must submit to the Customs Department a list showing the names and identity card numbers of his tappers, the area in which he proposes to tap, the quantity of toddy he has contracted to supply, and the number of coconut trees he proposes to tap in order to obtain the required quantity of toddy. Generally speaking, the Customs Department allows a tapper a task of 25 trees and estimates that the task should produce a minimum average of 10 gallons per day. An officer of the Customs Department inspects the area in which toddy tapping is proposed and toddy tapping can start only when approval from the Customs Department has been given. ${ }^{\text {cxviii }}$

He has to keep proper accounts showing the quantity of toddy brought in by each his tappers daily, and to submit monthly returns to the Customs Department showing the number of employees he has and the total monthly production of toddy. If he fails on any day to supply to a Government toddy shop the required quantity of toddy, he has to pay the Customs Department a surcharge which is penalty. Surcharge is imposed on a contractor as one of the measures to prevent toddy going into the "black market". In practise the contractor is penalised only in the absence of a satisfactory explanation for any short supply. If the contractor supplies more than he has undertaken to supply, he is paid for the actual quantity of toddy sold. cxix $^{\text {. }}$

To ensure the sale of quality toddy to the customer, a form of control was imposed with the existence of the office of toddy inspector. ${ }^{\text {cxx }}$ The Customs Department has its own staff to ensure effective control of toddy. Preventive officers and toddy inspectors of the Customs Department are often seen making check-ups in tapping areas or in other places where there is suspicion of toddy being sold or hidden away. Toddy inspectors visit all toddy shops to check up the quality of toddy.

The position is that toddy can be sold and consumed only in authorised shops. In any Government toddy shops it is the duty of the manager or clerk to report to the toddy inspector in charge of the area any unconsumed toddy left from the previous day and the toddy thrown away in the presence of the inspector. In the case of an estate toddy shop, the unconsumed toddy thrown away by the estate manager or his authorised representative. ${ }^{\text {cxi }}$

\section{Toddy Business}

Before the British Government introduced the toddy business, the Indian labourers consume toddy in a small scale. As time went by these labourers became more addicted and consume toddy on a widest scale after the British Government open up more toddy shops. In other words these drinkers solely dependent on these drinks for their survival. The British Government realised that by opening more toddy shops in various estates in Malaya, they found that these business more lucrative thus, controlling the staffs going out of their estates and making them work round a clock together with the drink. 
Furthermore, The British Government realised that these drink more favourable to the Indians especially labour groups. Owing to the following reasons:- firstly the profit from the sale of toddy, secondly the weakness of these Indians in the estates, thirdly the supports they received from the estate workers especially the male group and fourthly thereby controlling the labourers and making them slaves in all aspects as motivated the British Government to make huge profits from the toddy business. The writer hereby confirms that these workers were made like slaves, not disobeying the British Government and arguing with them any time during their tenure of their service.Two types of toddy business were carried out in Malaya, the Licensed Toddy Business and the Unlicensed or Illegal Toddy Business. Licensed Toddy Business is legally carried out in estates as well as in town areas. $^{\text {cxxii }}$ This was because the majority of Indians in Malaya were of the labour class, and the majority of labourers were placed in plantations, while the rest were in mining, the Public Works Departments (P.W.D), and the Railway Department. Unlicensed or Illegal Toddy Business was carried out outside of toddy shops. ${ }^{\text {cxxiii }}$ The two types of toddy businesses were carried out by the labourers, and this meant the toddy drinkers and retailers were also Indians.The two types of businesses involved three types of toddy, which were Fresh toddy / Undoctored toddy, Doctored toddy / Fermented Toddy, and Adulterated toddy / Impure toddy. Even though in licensed toddy business, Fermented Toddy, or Adulterated toddy were prohibited, most retailers desiring huge profits would include foreign substances in the toddy to attract more customers. As explained previously, the foreign substances mixed into pure toddy would increase intoxication. Samsu was also a favourite of the Indian workers if toddy was unavailable.

According to the High Commissioner of Malaya, R.H.Oakeley,

"Prohibition of toddy is seldom effective. Prohibition in America demonstrated that; the prohibition of chandu in Singapore and the Federation is an example nearer home. It seems unreasonable that the Indian labourers should not be allowed their national drink when Scotsmen, Chinese, and others are allowed theirs. Toddy in reasonable quantities is no more harmful than is beer is reasonable quantities. Toddy is much cheaper than is beer or samsu. If we force labourers to buy beer instead of samsu, they will be very much less money for their food, and not only the labourer but the family will suffer. On the other hand, if toddy is allowed, the actual number of persons who take intoxicants will be greater than if it is not permitted. The existence of a toddy shop on an estate is an encouragement to the labourers to take toddy." "cxxiv

\section{Licensed Toddy Business}

Licensed Toddy Business is divided into two parts. In the first part, the author will discuss the development of toddy sales in states with a large Indian population. In the second part, the discussion is on toddy sales in states with a small Indian population. The first policy was to open toddy shops in a large scale in states with a large Indian population. The second policy was to open toddy shops in a smaller scale in states with a small Indian population. The third policy was total prohibition. This means the British used different policies in different states for the purpose of profit.

The sale of toddy in the Straits Settlements, the Federated Malay States, and the Unfederated Malay States ${ }^{\text {cxxv }}$ was done in the same manner. Toddy sales in rural areas, especially in the plantations, were more rapid compared to sales in towns, as estate labourers constituted the largest toddy customers. Sale of arrack, samsu (a Chinese preparation) and foreign liquors to Indian labourers is prohibited by law. ${ }^{\text {cxxvi }}$ The Indian labourer perception of toddy as a healthy beverage was the main reason of their consumption of toddy. More importantly, toddy was cheap and available in estates, compared to other drinks. ${ }^{\text {cxvii }}$ Compared to Malay and Chinese labourers, the majority of Indian labourers were placed in plantations and received small wages. ${ }^{\text {cxxviii }}$ These labourers were subject to estate regulations and could not leave the estate area. ${ }^{\text {cxix }}$ The total number of Indian labourers dominating the estates is shown in Table 1.

Table 1 Total number of labourers in the plantation industry in Malaya, by race (in 000)

\begin{tabular}{|l|l|l|l|}
\hline Year & Indian & Chinese & Malay \\
\hline 1936 & 191195 & 60842 & 27559 \\
\hline 1937 & 243999 & 75589 & 36251 \\
\hline 1938 & 214610 & 58263 & 25987 \\
\hline 1939 & 218548 & 76376 & 40295 \\
\hline 1940 & 221391 & 86053 & 45931 \\
\hline
\end{tabular}

Source: S. Nanjundan, Indians in Malayan Economy, New Delhi: Office of the Economic Adviser to the Government of India, 1950, p. 15. 
Table 1 shows the total number of Indian labourers dominating the plantation sector in Malaya. The total number of Indian labourers from 1936 to 1940 was large compared to Chinese and Malay labourers in estates. This meant toddy retail was more focused in plantations compared to towns or villages, where the majority of residents were Chinese and Malays. As the largest clients were concentrated in the plantations, the British opened estate toddy shops at a large scale compared to public and government toddy shops. This is also reflected in Table 2.

Table 2 Total Estate, Public, and Government Toddy Shops in Malaya from 1926 to 1935

\begin{tabular}{|l|l|l|l|}
\hline Year & Estate Toddy Shop & Government Toddy Shop & Public Toddy Shop \\
\hline $\mathbf{1 9 2 6}$ & 328 & 70 & 15 \\
\hline $\mathbf{1 9 2 7}$ & 544 & 146 & 20 \\
\hline $\mathbf{1 9 2 8}$ & 587 & 144 & 25 \\
\hline $\mathbf{1 9 2 9}$ & 618 & 126 & 26 \\
\hline $\mathbf{1 9 3 0}$ & 623 & 99 & 39 \\
\hline $\mathbf{1 9 3 1}$ & 467 & 71 & 47 \\
\hline $\mathbf{1 9 3 2}$ & 388 & & 142 \\
\hline $\mathbf{1 9 3 3}$ & 396 & & 132 \\
\hline $\mathbf{1 9 3 4}$ & 474 & & 119 \\
\hline $\mathbf{1 9 3 5}$ & 501 & & 119 \\
\hline
\end{tabular}

Source: Adapted from, Annual Report of The Agent of The Government of India In British Malaya For The Year 1927-1933, Calcutta: Government of India, Central Publication Branch, 1928-1934 \&Annual Report of The Agent of The Government of India In British Malaya For The Year 1934-1935, Delhi: Manager of Publication, 19351936.

\section{Indian-majority Areas}

As explained, the British used a different policy in certain states. The British were more focused in increasing the number of toddy shops in areas where the majority population was Indian labourers due to the high demand of toddy.

In Malaya, areas settled by the majority of Indians were found in the states of Selangor, Perak, Kedah, Johore, Malacca, Penang, and Negeri Sembilan. At the time, Perak and Selangor were the main focus of the British, as they had the largest number of plantations. Toddy sales in Selangor and Perak existed in the three forms of estate, government, and public toddy shops. Licensed toddy business in Perak and Selangor began in 1910 under the toddy plantation system. ${ }^{\mathrm{cxx} x}$ Under this system, the government bought toddy directly from the coconut plantations and supply them to estate toddy shops. As this process complicated the process of supply and supervision of toddy shops, as well as the need for higher rent and revenue, in 1911 the government suggested a tender and licence system to open toddy shops in estates and towns. This new system was well-received, as each retailer has the opportunity to manage their private toddy shop after obtaining their tender and licence.

However, toddy shops were still under government purview. ${ }^{\text {cxxxi }}$ In 1912, the government opened tender for toddy shops in each district in Selangor. ${ }^{\text {cxxxii }}$ In Perak in 1918, 21 toddy shops for Larut district and 24 toddy shops for Kinta district were offered under the new tender system. ${ }^{\text {cxxxiii }}$ Under the Excise Enactment, the government opened 22 new toddy shops in estates in Kuala Lumpur for the first six months, and 20 shops for the last six months of 1913. ${ }^{\text {cxxiv }}$ In 1914 and 1915, the licence and tender system was introduced state wide in Selangor. ${ }^{\text {cxxxv }}$

Under the licence and tender system, those who wanted to obtain a licence for opening a toddy shop must get the tender from the Customs Department. Usually in Perak and Selangor, priority for issuing licences was given to the highest bidder. However, if the applicant offering the highest tender was suspicious and has caused problems on a previous occasion, licence would be given to the second-highest bidder. The tender-based toddy business is shown in Table 3. 
Table 3 List of location and tender holders to open toddy shops in districts in Selangor in 1917

\begin{tabular}{|l|l|l|l|}
\hline No. & Location & Tender Holder & Total $\mathbf{( \$ )}$ \\
\hline 1 & Kuala Selangor & N. Ramasamy Nadar & 116 \\
\hline 2 & Kampong Kuantan & A. Thankiah & 759 \\
\hline 3 & Asam Jawa & V. Naliah & 1019 \\
\hline 4 & Jeram & A.Subramaniam & 811 \\
\hline 5 & Bukit Blimbing & R. Kandasamy & 455 \\
\hline 6 & Batang Berjuntai & P. Gnanamuttu & 557 \\
\hline 7 & Batu 8 Jalan Rawang & M. Ramasamy Chetty & 537 \\
\hline 8 & Sabak Bernam & S. Vellaisamy & 75 \\
\hline 9 & Bagan Trap & S. Vellaisamy & 65 \\
\hline 10 & Sungei Dungun & Pengurus Raja Una Co. Ltd & 100 \\
\hline
\end{tabular}

Source: Adapted from, CO 439/3, Federated Malay States, Selangor Administration Report For The Year 1917, Kuala Lumpur: The F.M.S. Government Printing Office, 1918, p. 6 \& Tenders for Toddy Shop in Kuala Selangor District for 1917 Recommendations acceptance, in, Selangor Secretariat File, 5970/1916.

According to Table 3, in 1916, 10 areas in the Kuala Selangor district were listed as potential areas for opening toddy shops. ${ }^{\text {cxxxvi }}$ The total number of tenders in 1917 amounted to \$4,378, higher than in 1916, around \$3,733.50. Based on Table 3, tender holders in Kuala Selangor, Kampung Kuantan, Asam Jawa, Batu 8 Jalan Rawang, Batang Berjuntai, and Bagan Trap obtained tenders to open toddy shops in these locations as they offered the highest bid. In Bukit Belimbing, there were four applicants for the toddy shop licence: A. Thankiah, S. Muttiah, O. Chelliah, and R. Kandasamy. Even though A. Thankiah offered the highest bid of \$539, he did not get the tender as he had obtained a previous tender for a toddy shop in Kampung Kuantan. The British did not give the tender S. Muttiah who offered $\$ 509$ as they did not know him. O. Chelliah who offered $\$ 479$ also did not get the tender as he was a business partner of a toddy shop known for selling old toddy and has caused trouble before. The tender finally went to R. Kandasamy who offered the lowest bid of $\$ 455$ to open a toddy shop in Bukit Belimbing. ${ }^{\text {cxxxvii }}$

The relatively easy, wide-spread, and open awarding of licences, as well as disorganised inspection and surveillance of toddy shops led to the selling of adulterated toddy in licensed toddy shops. ${ }^{\text {cxxxviii }}$ To prevent this problem, in the 1915 Customs Enactment, the two-fifths system was introduced in Perak and Selangor. The toddy shops in this system were only for estate labourers, and the sales account must be in order. Through this system, each licensed estate or government toddy shop owner must hand two-fifths of their sales revenue to the Customs Department every month, and the remaining profit spent wholly for the facilitation and benefit of the estate Indian labourers. ${ }^{\text {cxxix }}$ The total amount channelled depended on the number of Indian labourers in the estates, as the Indian labourers in estates spent a large amount of their wages on toddy and faced financial problems in supporting their family. ${ }^{\text {cxl }}$

Toddy retail under the licence and tender system continued until 1918. ${ }^{\text {cxli }}$ By 1919, the two-fifths system was introduced in a number of districts in Selangor ${ }^{\text {cxlii }}$ and applied state-wide in 1922. ${ }^{\text {xliii }}$ At the end of 1922, all toddy shops in plantations in Kuala Langat used the two-fifths system whereby profits from the sales were donated to the temple fund and for other reasonable causes. ${ }^{\text {cxliv }}$

In Ulu Langat district, there were eight licensed toddy shops in estates, which were the Sungai Rinching, Dunedin, Balau, Semenyih, Glengowrie, Sydney, Bhutan, and Rinching estates, which used the two-fifths system. At the time, the Licensing Board decided to eliminate all public toddy shops and convert them to estate and government toddy shops to facilitate surveillance and inspection. ${ }^{\text {cxlv }}$ Even though the two-fifths system was introduced, many still sold the doctored or impure toddy for higher profit, which negatively affected the health of the workers. ${ }^{\text {cxlvi }}$ Table 4 shows the toddy business under the two-fifths system in estates in Selangor. 
Table 4Total revenue from toddy shops in Kuala Langat, Selangor under the two-fifths system in 1922.

\begin{tabular}{|l|l|l|}
\hline No. & Toddy Shop & $\begin{array}{l}\text { Revenue received by the Government } \\
\mathbf{( \$ )}\end{array}$ \\
\hline 1 & Banting Estate & $2,523.12$ \\
\hline 2 & Bandar Estate & $1,153.88$ \\
\hline 3 & Brooklands North & $1,508.44$ \\
\hline 4 & Brooklands South & 755.32 \\
\hline 5 & Bedford Estate & $1,269.86$ \\
\hline 6 & Durian Dusun Estate & $2,738.16$ \\
\hline 7 & Gadong Estate & $1,131.94$ \\
\hline 8 & Klanang Estate & $1,893.96$ \\
\hline 9 & Permatang Pasir & $1,440.00$ \\
\hline 10 & Estate Sungei Buaia & $4,429.56$ \\
\hline 11 & EstateTumbuk & $2,103.48$ \\
\hline Total & & $20,947.72$ \\
\hline
\end{tabular}

Source: Government Policy as to toddy shop in Kuala Langat, in Selangor Secretariat File, 511/1923.

Toddy sales in Perak and Selangor under the licensing and tender, and later the two-fifths, system continued up until the Japanese Occupation. Toddy intake among Tamil estate labourers in Perak was also widespread. Almost all divisions in estates have their own toddy shop. For example, there were three toddy shops in the Jendarata Estate, which had three divisions: Division I, II, and III. ${ }^{\text {cxlvii }}$ The total number of toddy shops led to the increase in demand for toddy. For example, around 108,128 1/2 gallons of toddy were sold to labourers in 1931, and by 1934, this number increased to $1,076,968$ gallons. ${ }^{\text {cxlviii }}$ Total sales of toddy increased in the following year, with $1,228,330$ gallons of toddy sold to Indian labourers. ${ }^{\text {cxlix }}$ Toddy sales increased to 1,235,165 gallons in $1936^{\mathrm{cl}}$ and $1,543,905$ gallons in $1937 .{ }^{\text {cli }}$ The increase in revenue is closely related to the opening of toddy shops in a large scale in Perak and Selangor. The rapid growth of toddy shops is recorded in Table 5.

Table 5 Total Number of Government, Public, and Estate Toddy Shops in Perak and Selangor,1931-1939.

\begin{tabular}{|l|l|l|l|l|}
\hline Year & $\begin{array}{l}\text { Government Toddy Shop } \\
\text { (Perak) }\end{array}$ & $\begin{array}{l}\text { Public Toddy Shop } \\
\text { (Perak) }\end{array}$ & $\begin{array}{l}\text { Estate Toddy Shop } \\
\text { (Perak) }\end{array}$ & $\begin{array}{l}\text { Estate Toddy Shop } \\
\text { (Selangor) }\end{array}$ \\
\hline 1931 & 19 & 12 & 113 & - \\
\hline 1932 & 18 & 12 & 104 & - \\
\hline 1933 & 18 & 12 & 104 & - \\
\hline 1934 & 19 & 12 & 112 & 34 \\
\hline 1935 & 19 & 15 & 122 & 40 \\
\hline 1936 & 21 & 13 & 135 & 41 \\
\hline 1937 & 22 & 12 & 145 & 43 \\
\hline 1938 & 23 & 12 & 148 & 44 \\
\hline 1939 & - & - & - & 45 \\
\hline
\end{tabular}

Source: Adapted from, CO 438/5, Federated Malay States, Perak Administration Report For The Year 1931, Kuala Lumpur: The F.M.S. Government Printing Office, 1932; Federated Malay States, Annual Report On The Social and Economic Progress of The People of Perak For The Year 1933-1939, Kuala Lumpur:

The F.M.S. Government Press, 1934-1940; CO 439/4, Federated Malay States, Annual Report On The Social and Economic Progress of The People of Selangor For The Year 1934-1939, Kuala Lumpur: The F.M.S. Government Press, 1935-1940.

According to Table 5, the number of estate toddy shops continued to increase in Selangor and Perak, as opposed to government and public toddy shops in the 1931-1939 period, as the Indian estate labourer was the main target of the British in the selling of toddy. This factor was important in the decision to open toddy shops at a large scale. In addition, in 1933, the government reduced the retail price of toddy in all estate toddy shops in Perak, from 10 cents to six cents for a pint of toddy. This of course led to the increase in toddy consumption among the Indian labourers. ${ }^{\text {clii }}$ The growth of toddy shops also increased toddy sales revenue. In Table 6 , it shows toddy sales increased in the 1932-1938 period. Increasing demand for toddy led to increase in total sales. 
Table 6 Total revenue of Government and Estate toddy shops in Selangor from 1932 to 1938.

\begin{tabular}{|l|l|l|}
\hline Year & Revenue from Government Toddy Shop & Revenue from Estate Toddy Shop \\
\hline 1932 & $\$ 157,300$ & $\$ 57,000$ \\
\hline 1933 & $\$ 130,300$ & $\$ 48,000$ \\
\hline 1934 & $\$ 128,800$ & $\$ 62,700$ \\
\hline 1935 & $\$ 135,560$ & $\$ 71,200$ \\
\hline 1936 & $\$ 149,500$ & $\$ 75,120$ \\
\hline 1937 & $\$ 167,445$ & $\$ 89,402$ \\
\hline 1938 & $\$ 175,964$ & $\$ 92,350$ \\
\hline
\end{tabular}

Source: Adapted from, CO 439/4, Federated Malay States, Annual Report On The Social and Economic Progress of The People of Selangor For The Year 1934-1939, Kuala Lumpur: The F.M.S. Government Press, 1935-1940; Federated Malay States, Annual Report On The Social and Economic Progress of The People of Selangor For The Year 1932-1938, Kuala Lumpur: The F.M.S. Government Press, 1933-1939.

The growth of toddy shops is generally dependent on the total number of estates in a particular state, and this indirectly decided the total number of labourers in a particular state. This situation led to the widespread opening of toddy shops. The development of plantations is shown in Table 7.

Table 7 Total number of estates in Malaya in 1934 and 1935

\begin{tabular}{|l|l|l|}
\hline State & Total Estate 1934 & Total Estate 1935 \\
\hline Federated Malay States (FMS) & 2,178 & 2,345 \\
\hline Straits Settlements (SS) & 335 & 334 \\
\hline Unfederated Malay States (UFMS) & 324 & 485 \\
\hline
\end{tabular}

Source: Annual Report of The Agent of The Government of India In British Malaya For The Year 1935, Delhi: Manager of Publication, 1936, pp. 36-37.

Other than Perak and Selangor, the policy of opening toddy shops at a large scale was also practised in the Unfederated Malay States, especially in Johore and Kedah, which were targeted by the British for the large number of labourers and estates there. ${ }^{\text {cliii }}$ The same situation was also identified in the Straits Settlements of Malacca and Penang. In Malacca, estate toddy shops were opened in a large scale in plantation areas. ${ }^{\text {cliv }}$ By 1924 , the two-fifths system was offered to estate managers, but all managers rejected this system. However, this system was later accepted after a number of years as a large amount were set aside for labour welfare and rent was fixed. $^{\text {clv }}$ Meanwhile, toddy sales in Penang were fully dependent on estate and public toddy shops, and government toddy shops were non-existent. As in Malacca, the Penang government ran toddy shops under the two-fifths system, and paid a fixed rent. ${ }^{\text {clvi }}$

The licensed toddy sales in Johore and Kedah were similar as in previous cases, whereby three types of toddy shops existed: the government, estate, and public. The award of tenders prioritised the highest bidder with a good business track-record. However, there was some difference in the tender and licensing system issued in Kedah. ${ }^{\text {clvii }}$ In Kedah, the awarding of tenders was based on the price of toddy per gallon, in contrast to other states that stressed on awarding tender based on monthly or annual rent. The price of gallon (tender) was set by the government according to area, where in some areas tender was awarded to the bidder with the lowest price per gallon. Tender was awarded to those with no bad record. 
Table 8 List of location and tender holder to open toddy shops in districts in Kedah in 1946

\begin{tabular}{|c|c|c|c|}
\hline Toddy Shop & Tender Applicant & $\begin{array}{l}\text { Prince of tender } \\
\text { per gallon } \\
\text { (cents) }\end{array}$ & Reason to support applicant \\
\hline 1.Alor Setar & S. M. Sethumathavan Pillai & 16 cents & $\begin{array}{l}\text { Two people, S. M. Sethumathavan Pillai \& S. M. S. P. Subramanian Servai offered tender for the } \\
\text { Alor Star toddy shop for the same price of } 16 \text { cents a gallon. The Customs Department supported } \\
\text { S.Pillai as he provided toddy to the Alor Star toddy shop in } 1945 \text { and was a government toddy } \\
\text { contractor during the pre-war period, while Subramaniam was quite new to the toddy business and } \\
\text { was never a government contractor. }\end{array}$ \\
\hline 2.Anak Bukit & S. V. Kata Muthu & 13 cents & Lowest tender bid \\
\hline 3.Jitra & K. Karpaya & 13 cents & Same as above \\
\hline 4.Guron & $\begin{array}{l}\text { S. M. S. P. Subramanian } \\
\text { Servai }\end{array}$ & 11 cents & Same as above \\
\hline 5.Bedong & A.Ratnasamy Nadar & 15 cents & Same as above \\
\hline 6.Sungai Petani & K.Pokkan & 16 cents & $\begin{array}{l}2 \text { people, K. Pokkan \& Kannavello sent tenders for the same price of } 16 \text { cents per gallon. The } \\
\text { Customs Department chose the first person as he submitted his tender earlier }(23.10 .45) \text { than the } \\
\text { second person }(30.10 .45) \text {. They were new in this field. }\end{array}$ \\
\hline 7.Semeling & M. Karpaya & 16 cents & Lowest tender bid \\
\hline 8.Sungai Lalang & P. Andiappen & 17 cents & Same as above \\
\hline 9.Sungai pasir & Muna Veraya & 15 cents & Same as above \\
\hline $\begin{array}{ll}\text { 10.Sungai } & \text { Tok } \\
\text { Pawang } & \\
\end{array}$ & V. O. Waddiappah & 13 cents & Same as above \\
\hline 11.Kuala Ketil & Ramasamy & 13 cents & $\begin{array}{l}2 \text { people, Ramasamy \& V. Sundram Naidu sent tenders for the same price of } 13 \text { cents per gallon. The } \\
\text { Customs Department chose the first applicant as he submitted his tender earlier }(23.10 .45) \text { than the } \\
\text { second person }(28.10 .45) \text {. }\end{array}$ \\
\hline 12.Kupang & V. Sundram Naidu & 14 cents & Lowest tender bid \\
\hline 13.Kulim & Kanan Vello & 20 cents & Same as above \\
\hline 14.Lunas & R. Doraisamy & 21 cents & Same as above \\
\hline 15.Serdang & M. Marimuthu & 20 cents & Same as above \\
\hline $\begin{array}{l}\text { 16.Sungai Kechik } \\
\text { Ulu }\end{array}$ & Andi Nadar & 20 cents & He was the only applicant \\
\hline 17.Bandar Baru & A. K. Veeman & 22 cents & He was the only applicant \\
\hline 18.Padang Serai & Muna Veraya & 19 cents & Lowest tender bid \\
\hline 19.Merbau Pulas & Manikam Naidu & 13 cents & Same as above \\
\hline 20.Sungai Karangan & Manikam Naidu & 15 cents & Same as above \\
\hline
\end{tabular}

Source: Tender for the supply of Toddy to Government Toddy Shops During 1946, in Kedah Secretariat File 284.

Based on Table 8, it is clear that the people that offered the lowest price per gallon got the tender. Those without a clean record or experience in the toddy field were overlooked, as seen in the case of Subramaniam of Alor Star. If there was no other applicant for a particular area, the only applicant would get the tender even if he was less qualified. In another case, Manikam Naidu was awarded tenders for two areas as his price was lower compared to other bidders. The widespread awarding of licences and tenders in Kedah increased the number of toddy shops.

Table 9 and figure 1 clearly outlined the development of estate toddy shops in Kedah. The total number of estate toddy shops in Kedah in 1934 was 75 licensed toddy shops in 56 plantations. In 1935, the number increased to 82 shops, and then to 84 shops in 60 plantations. In 1937, there were 90 toddy shops in 64 plantations, an increase from the previous years. ${ }^{\text {clviii }}$ Evidently, the total number of toddy shops in Kedah exceeded the number of plantations. This was due to the existence of divisions within an estate, and toddy shops were opened in almost all divisions.

Table 9 Total number of Government, Public, and Estate Toddy Shops in Kedah in 1928-1937

\begin{tabular}{|l|l|l|l|}
\hline Year & Government Toddy Shop & Public Toddy Shop & Estate Toddy Shop \\
\hline 1928 & Nil & 29 & 89 \\
\hline 1929 & Nil & 31 & 115 \\
\hline 1930 & 1 & 24 & 98 \\
\hline 1931 & 3 & 16 & 112 \\
\hline 1932 & 5 & 14 & 65 \\
\hline 1933 & 6 & 12 & 75 \\
\hline 1934 & 5 & 12 & 75 \\
\hline 1935 & 5 & 10 & 82 \\
\hline 1936 & 8 & 7 & 84 \\
\hline 1937 & 8 & 6 & 90 \\
\hline
\end{tabular}

Source: Annual Report on The Social and Economic Progress of The People of The State of Kedah For The Year 1355 A.H. \& 1356 A.H., Alor Setar: The Kedah Government Press, 1937 \& 1938; Annual Report of The Labour Department Kedah For The Year 1353, in Kedah Secretariat File 810/1354. 
Figure 1 Total number of Government, Public, and Estate Toddy Shops in Kedah in 1928-1937

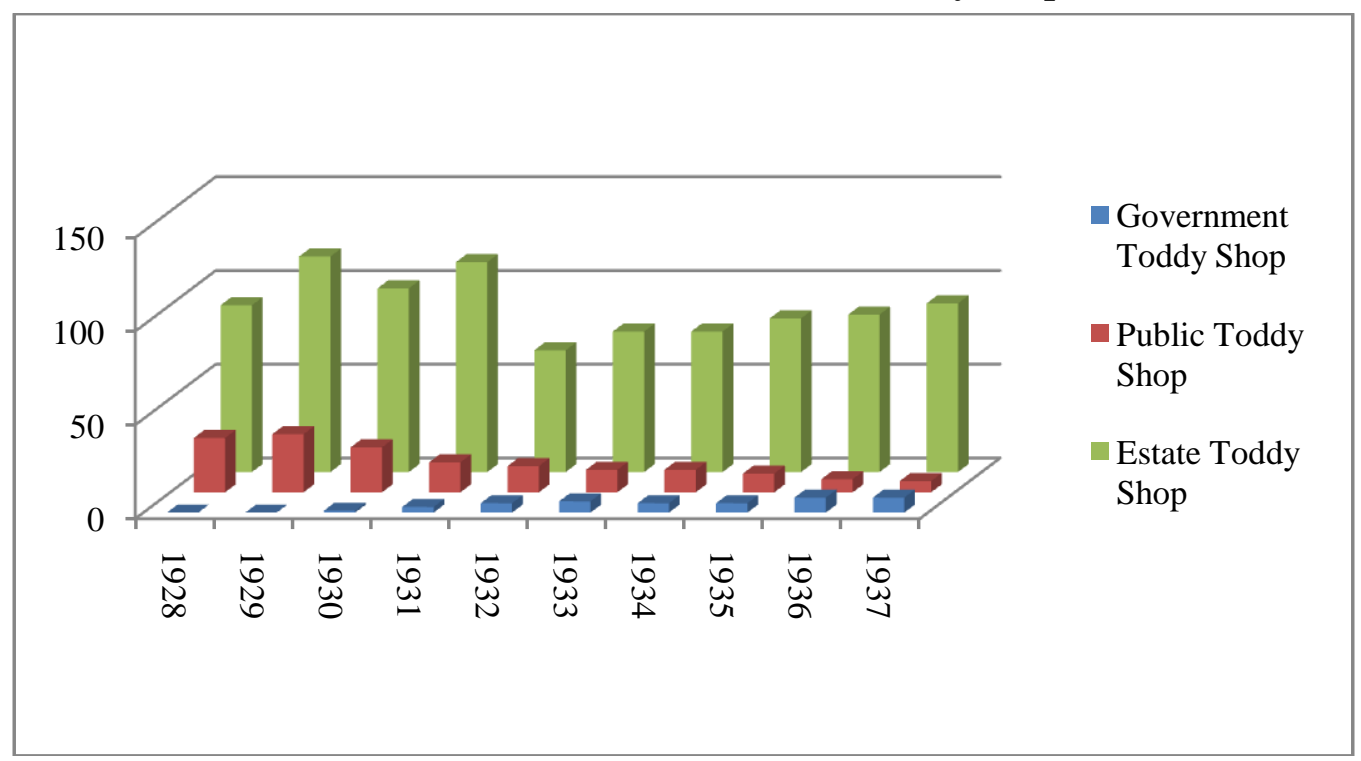

Source: Adapted from, Annual Report on The Social and Economic Progress of The People of The State of Kedah For The Year 1355 A.H.\&1356 A.H., Alor Setar: The Kedah Government Press, 1937 \& 1938; Annual Report of The Labour Department Kedah For The Year 1353, in Kedah Secretariat File 810/1354.

The licensee who is out to make a big profit on his shop would be a fool if he did not sell on credit. Sale on credit is illegal. He cannot legally recover such a debt, and he of course now and then gets "done" by his debtor, but on the other hand the coolie is often short of cash, and if the lessee did not sell on credit his sales would fall tremendously. What is easier than to lend the coolie a dollar and get a note of hand for $\$ 1.50$ and recover on pay day. ${ }^{\text {clix }}$

There is some evidence of toddy sales by-credit. For example, in Krian, Perak Government closed down suddenly shops run by estate nominees, with ample proof that there was a regular system on credit and even in estate shops run on the $2 / 5^{\text {th }}$ system credit has been given in a few cases by dishonest clerks in charge. ${ }^{\text {clx }}$ In a toddy shop at $31 / 2$ Mile, Kuala Langat Road, Selangor, in 1916, toddy drinkers were found drunk due to toddy retailers allowing customers to drink by-credit. ${ }^{\text {clxi }}$ This situation was also identified in other states. In Batu Pahat, Johore, a toddy shop owner known as Kathamuthu sold toddy by-credit to the labourers. ${ }^{\text {clxii }}$

Discussion on toddy business in states with a large number of Indian labourers shows the British adopted a liberal policy regarding the opening of toddy shops to reflect the large number of estates and Indian labourers. The support for this policy came from the retailers as well as the government.

\section{Indian-minority Areas}

The sale of licensed toddy also occurred among Indian-minority areas, especially in the East Coast states of Kelantan, Terengganu, and Pahang. The policy in these areas was the British allowed the opening of toddy shops at a small scale. This was due to the low number of estates and Indian labourers.

At the early stages, the toddy business in Kelantan was based on two types: the estate and the public toddy shops. ${ }^{\text {clxiii }}$ This was because the Indian labourers were brought to Kelantan specifically to work in plantations and not the towns. Compared to Selangor and Johore, there was a significant difference in total labourers, as workers in the two states were many and allocated according to occupation in urban and rural areas. This then led to the need for a government toddy shops. In Kelantan, government toddy shops were never opened due to the low number of labourers. ${ }^{\text {clxiv }}$ The public toddy shop in Kelantan was based on the tender system, while the estate toddy shop was based on the one-fifth system under estate manager supervision. The one-fifth system was similar to the two-fifth system applied in Selangor and Perak, whereby one-fifth of profits were paid to the government, and the rest used for labour welfare. ${ }^{\text {clxv }}$ 
The opening of toddy shops received encouragement and support from employers. To them, toddy shops must be opened for the good of the worker, and at the same time it prevents the sale of illicit toddy, including the sale of samsu. For example, in 1916, the managers of the Taku, Kuala Nal, Kuala Geh, and Pasir Gajah estates firmly argued for the provision of toddy for labourers, as $60 \%$ of Indian estate labourers in Kelantan were drinkers. ${ }^{\text {clxvi }}$ Even though they were small in number and demand for toddy was not as high compared to other states, the British and estate managers realised toddy's usefulness in binding the labourers to the plantations. To this end, the British opened toddy shops according to need and demand.

Table 10 Toddy shops and revenue in Kelantan 1934-1940

\begin{tabular}{|l|l|l|l|}
\hline Year & Public Toddy Shop & Estate Toddy Shop & Total Revenue \\
\hline $\mathbf{1 9 3 4}$ & 10 & 8 & $\$ 8,051.93$ \\
\hline $\mathbf{1 9 3 5}$ & 9 & 7 & $\$ 9,540.06$ \\
\hline $\mathbf{1 9 3 6}$ & 10 & 7 & $\$ 11,229.36$ \\
\hline $\mathbf{1 9 3 8}$ & 13 & 13 & $\$ 16,033.45$ \\
\hline $\mathbf{1 9 3 9}$ & 12 & 12 & $\$ 14,131.37$ \\
\hline $\mathbf{1 9 4 0}$ & 9 & 11 & $\$ 13,285.11$ \\
\hline
\end{tabular}

Source: Adapted from, Number of Government, Public and Estate toddy shops in each of the Unfederated Malay States which catered to Indian labourers and the total amount of revenue derived there from during the year 1934, 1935, 1936, in British Adviser's Office Kelantan File, BAOK 87/1935 \& Number of Government, Public and Estate toddy shops in each of the Unfederated Malay States which catered to Indian labourers during the year 1938, 1939, 1940, in British Adviser's Office Kelantan File, BAOK 179/1939.

Table 10 shows the revenue and total number of toddy shops in Kelantan in 1934-1940. Even though the state has a small number of labourers, the British still wanted to profit through the opening of toddy shops at a small scale.

Toddy sales in Terengganu generally only involved public toddy shops operating under a licensing system. ${ }^{\text {clxvii }}$ In the Terengganu state annual report, there were four public toddy shops and two estate toddy shops operating in 1938. In addition, there was a large toddy shop in Dungun due to the concentration of many Indian labourers working at the tin mine in that area. The Jabor Valley and Kretay estates, which had many Indian workers, opened licensed toddy shops operated by estate managers. ${ }^{\text {clxviii }}$ Large toddy shops were opened to accommodate the increase in labourer numbers in Terengganu. For example, the number of Indians increased from 602 people in 1934 to 931 people in 1935 . $^{\text {clxix }}$ Even though the number of Indian labourers in Terengganu was small compared to other states, the revenue that government gained from toddy sales increased annually. ${ }^{\text {clxx }}$ For instance, public toddy shop revenue in Terengganu in 1948 was $\$ 6,787$, which increased to $\$ 7,534$ in $1949 .{ }^{\text {clxxi }}$

Meanwhile, toddy sales in Pahang are still unclear. According to a report of the Agent of the Government of India in Malaya in 1930, there were only five toddy shops in Pahang in 1930. ${ }^{\text {clxxii }}$ This confirmed the existence of toddy business in Pahang, but at very small scale. This study shows Kelantan had the highest number of toddy shops, compared to Pahang and Terengganu. Two factors for this situation were the lack of high demand for toddy in Pahang, and the government of Pahang limiting the opening of estate toddy shops even though Indian labourers were present in the state.

In states with a small Indian labour population, the opening of toddy shops was prohibited by the British. This was evident in the case of Perlis, whereby licensed toddy business in the state during the colonial period was nonexistent. ${ }^{\text {llxxiii }}$ However, this situation does not negate the report stating there were around 95 licensed toddy shops operating in Kedah and Perlis before the Second World War involving collection of revenue of 12 cents per gallon, amounting to $\$ 150,000$ per annum. ${ }^{\text {clxxiv }}$ This meant the toddy shops in Perlis operated illegally.

Table 11 and Figure 2 clearly show the importance of toddy business to the government and without the Indian labourers, the British would not have encouraged this industry. The Federated Malay States produced huge profit from the toddy business compared to the Straits Settlements and the Unfederated Malay States. 
Table 11Total toddy revenue between 1925 and 1935 in Malaya

\begin{tabular}{|c|c|c|c|c|c|c|}
\hline $\begin{array}{l}\text { Year / } \\
\text { State }\end{array}$ & $\begin{array}{l}\text { Perak, Selangor, } \\
\text { Pahang, } \\
\text { Negeri Sembilan } \\
\text { (FMS) (\$) }\end{array}$ & $\begin{array}{l}\text { Penang, } \\
\text { Melaka, } \\
(\text { SS })(\$)\end{array}$ & $\begin{array}{l}\text { Kedah } \\
\text { (UFMS) } \\
(\$)\end{array}$ & $\begin{array}{l}\text { Johor } \\
\text { (UFMS) } \\
(\$)\end{array}$ & $\begin{array}{l}\text { Kelantan } \\
\text { (UFMS) } \\
(\$)\end{array}$ & $\begin{array}{l}\text { Terengganu } \\
\text { (UFMS) } \\
(\$)\end{array}$ \\
\hline 1925 & 973,044 & - & - & - & - & - \\
\hline 1926 & $1,142,690$ & - & - & - & - & - \\
\hline 1927 & $1,275,966$ & 746,505 & - & - & - & - \\
\hline 1928 & $1,325,416$ & 640,490 & - & - & - & - \\
\hline 1929 & $1,498,163$ & 656,598 & 225,245 & & & \\
\hline 1930 & $1,403,483$ & 703,469 & 217,829 & 90,049 & - & - \\
\hline 1931 & $1,031,156$ & 586,308 & 118,661 & 79,358 & 8,611 & - \\
\hline 1932 & 782,206 & 477,819 & 98,088 & 54,625 & 7,174 & - \\
\hline 1933 & 680,987 & 404,183 & 116,454 & 51,443 & 7,458 & 742 \\
\hline 1934 & 842,984 & $682,236.38$ & $142,976.55$ & $121,500.50$ & $8,051.93$ & 375 \\
\hline 1935 & 966,200 & 778,903 & 179,803 & 145,836 & 9,540 & 1,436 \\
\hline
\end{tabular}

Source: Adapted from Annual Report of The Agent of The Government of India In British Malaya For The Year 1926-1935, Calcutta: Government of India, Central Publication Branch, 1927-1936.

Figure 2 Total toddy revenue between 1925 and 1935 in Malaya

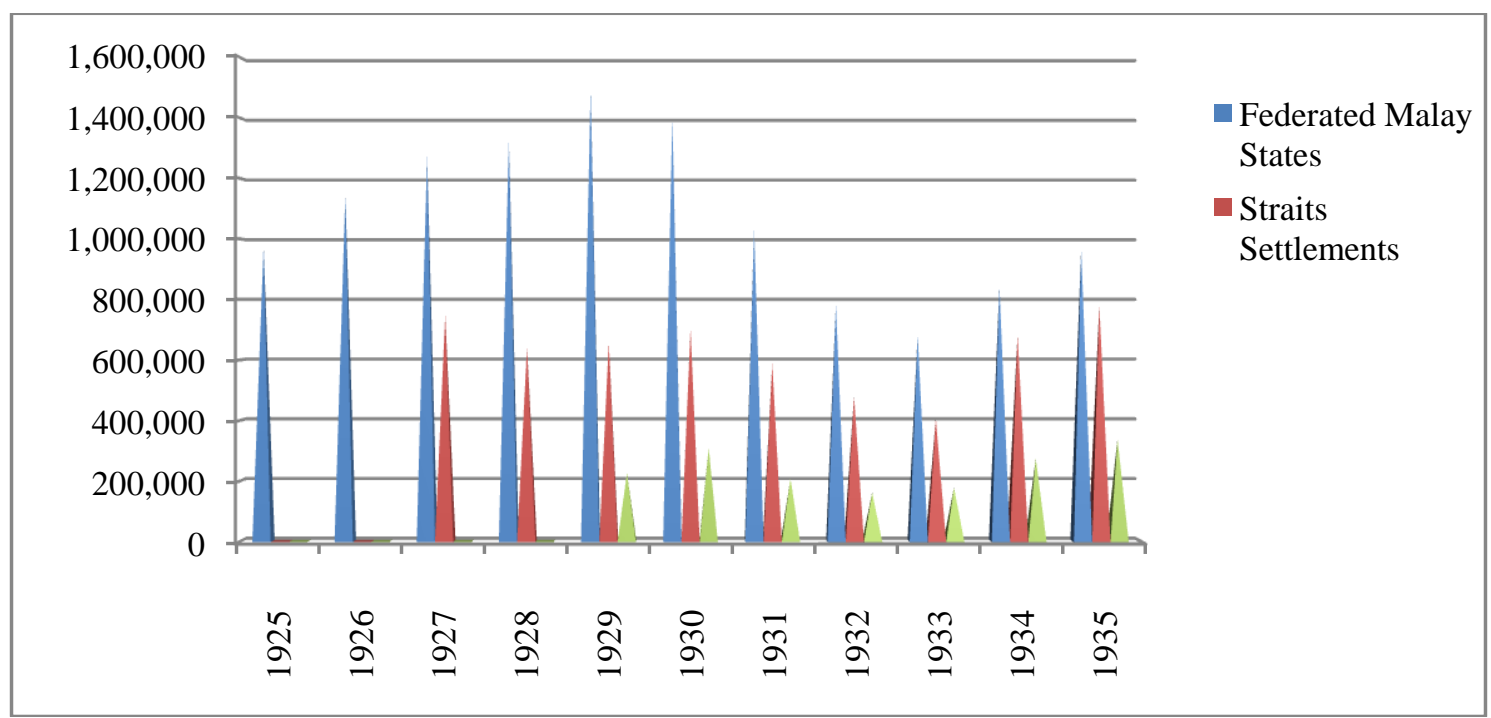

Source: Adapted from, Annual Report of The Agent of The Government of India In British Malaya For The Year 1926-1935, Calcutta: Government of India, Central Publication Branch, 1927-1936.

\section{Toddy Sales during the Japanese Occupation}

Sale of toddy during the Japanese Occupation should be addressed, as the Occupation brought about a significant change in toddy business in Malaya. The policy in existence, which was applied to all states, was total freedom. Before the war, the main customers of toddy were Indian labourers, but this extended to all labourers during the Japanese Occupation. This was because the Japanese encouraged more people to partake in toddy. This was part of the revenue used for strengthening the Japanese position and administration. Toddy intake was at the highest level due to the widespread availability of the beverage. ${ }^{\text {clxxv }}$

The Japanese, other than as a source of income, encourage the drinking of toddy for health reasons, believing it to have nutritional value especially in countering the spread of beriberi. In addition, labourers recruited to work at the Siamese death railway were encouraged to drink toddy for health reason and this was also extended to estate labourers. ${ }^{\text {clxxvi }}$ The Japanese expanded the toddy business as it was a good generator of revenue. ${ }^{\text {clxxvii }}$ Furthermore, 164 
the Japanese also encouraged toddy to prevent the Indian labourers from causing trouble for the administration. The Japanese also saw toddy as a method to collect information from undesirable elements. Lips get loose after drinking toddy, and this helped in the collection of information. ${ }^{\text {clxxviii }}$ The Japanese did not stop at mere encouragement, and even increased the opening of samsu and arak distilleries. For example in Selangor, the Japanese increased the number of distilleries from 91 (pre-war) to 200. Japanese effort in the sale of toddy, including arak and samsu, brought manifold profit as business was free and without restriction. ${ }^{\text {clxxix }}$

During this period, only two types of toddy shops were operating in Malaya, the government and the estate toddy shops. The government toddy shops were based on the contract system fully managed by the government. The estate toddy shops were maintained and managed by the estate manager for their workers. A contract system was established, based on a "fifty-fifty percentage basis", whereby a contractor maintaining a toddy shop must pay $50 \%$ of his revenue to the Japanese and keep the rest for himself. The application of this contract system was evident in Selangor, and the system, which was established in June 2602/1942, produced revenue of $\$ 62,996$. $^{\text {clxxx }}$

There was also an introduction of a contract system fully controlled by the government. Application for a contract to open a toddy shop was in the hands of the Japanese. ${ }^{\text {clxxi }}$ With the increase in toddy demand, the contractor took advantage with his widespread provision of toddy, legal and illegal. Usually, a part of the stored toddy would be sold out at the toddy collection centre at a high price. The rest of the toddy supplied to the toddy shop was of a

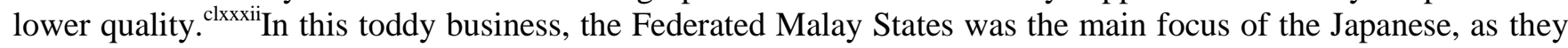
contained a high number of Indian labourers, which meant a higher demand of toddy.

Table 12 Toddy sales and revenue collected by the Japanese on 2602/1942 in Selangor.

\begin{tabular}{|l|l|l|l|}
\hline Month & Total Toddy Shop & Sale of Toddy (gallon) & $\begin{array}{l}\text { Total Revenue } \\
\mathbf{\$}\end{array}$ \\
\hline March & 10 & 15,023 & $6,120.98$ \\
\hline April & 16 & 36,770 & $15,015.66$ \\
\hline May & 21 & 50,840 & $20,768.35$ \\
\hline June & 24 & 51,693 & $21,091.28$ \\
\hline July & 24 & 50,309 & $41,146.95$ \\
\hline August & 27 & 52,834 & $43,138.15$ \\
\hline September & 29 & 53,014 & $43,279.34$ \\
\hline October & 29 & 56,750 & $45,949.48$ \\
\hline November & 29 & 55,034 & $44,585.60$ \\
\hline December & 29 & 53,277 & $43,596.85$ \\
\hline Total & & $\mathbf{4 7 5 , 5 4 4}$ & $\mathbf{3 2 4 , 6 9 2 . 6 4}$ \\
\hline
\end{tabular}

Source: Annual Report of The Customs and Excise Department, Selangor For The Year 1943, in Selangor Secretariat File, Syuseityo Kanbo 117/2603 (1943).

Based on Table 12, it was discovered that within a one year period, there was a significant increase in the opening of toddy shops in Selangor. In March 1942, ten new shops were opened, and this number increased to 29 shops at the end of the year. In line with the increase, the total revenue was also high at \$324,692.64.

After the Japanese Occupation ended, the Malayan Union Government took over the administration of Malaya. All toddy shops excepting government toddy shops opened before the war were closed down. ${ }^{\text {clxxxiii }}$ The power to sell toddy was only limited to towns and not to estates. This led to the existence of large-scale black market in the estates. As reported by estate managers, the labour condition during this time was 'severe intoxication' compared to in 1941 . The sale of $s a m s u^{\text {clxxiv }}$ was also wide-spread, and some labourers were reported spending a large amount of money on that drink. ${ }^{\text {clxxxv }}$ Managers of some estates state that they are losing their labourers to larger estates, that drinking of illicit toddy is being resorted to and labourers when offered overtime are refusing such work preferring to spend the time either walking or cycling to spend the afternoon wherever they can drink. On some estates widows of labourers who died in Siam now drink toddy. Black market toddy from toddy tappers is being bought at 40 cents per pint and samsu is being obtained from Chinese shopkeepers. ${ }^{\text {clxxxvi }}$

\section{Unlicensed or Illegal Toddy Business}

Unlicensed or Illegal Toddy Business was carried out without the possession of a licence. This business was conducted in toddy shops without a licence or somewhere outside of government purview. 
Toddy sold in this black market consisted of fresh or pure toddy and mixed toddy or toddy mixed with foreign substances that could lead to intoxication, such as old liquor, sugar, lime, ganja, and datura. ${ }^{\text {clxxxvii }}$ Samsu was also sold illegally. This black market was prevalent among the labour community. ${ }^{\text {clxxxiii }}$ Clearly, this business was conducted with profit in mind. ${ }^{\text {clxxxix }}$

Toddy was mainly enjoyed by the majority of Indians, while samsu was mainly consumed by the majority of Chinese. However, samsu was also consumed by some Indian labourers. Most Chinese labourers involved in the illegal making and selling of samsu targeted the Tamil worker, especially the estate labourers. ${ }^{\text {cx }}$ The majority of illicit distilleries have been found in the depths of the jungle, in mangrove swamps, in limestone caves, in leech infested swamps and even on open tin tailings where anyone approaching can be seen a long distance away. ${ }^{\text {cxci }}$

Some cases serve as evidence. In 1938, there were a number of cases in Perak which Tamil coolies were themselves engaged in distilling samsu. Illicit stills are frequently set up in remote places in jungle far from the distillers' houses and it is a matter considerable difficulty to obtain satisfactory cases. A case in which a large degree of ingenuity was exhibited was one in Perak, where an Outdoor Officer found a still in jungle and suspecting that it belonged to the occupant of a certain house. ${ }^{\text {cxii }}$

Some of the most important cases were detected in Selangor. In 1938, a still constructed on a sampan was discovered near Carey Island. It appears that the owner sailed out to sea whenever he wished to distil and returned with the liquor for sale amongst the coolies on the Island. In another case, a Sakai woman was arrested on Carey Island for supplying illicit samsu to Tamils.

A remarkable feature of this case was that she paid the fine; this pointed to the fact that she was making a considerable profit out of her samsu business. ${ }^{\text {cxiii }}$ In a jungle clearing about five miles from the village of Batu Arang, Selangor two huge stills of 40 gallons capacity each and 232 gallons of fermented liquor were seized. The Chinese who was operating the still was arrested and on prosecution was convicted and fined $\$ 1400$ or in default to undergo six months rigorous imprisonment. Another large seizure was affected at Batu Arang where deep in the jungle two Chinese were arrested with 148 gallons of liquor while in the act of distilling with two large wooden drum stills. Other important case is, two men engaged in distilling samsu on a large scale were arrested in a patch of jungle near Kapar, Selangor and were fine a total sum of $\$ 3,350$. $^{\text {cxciv }}$

In Negeri Sembilan information obtained that a lorry was used to carry illicit samsu. A trap was set with the assistance of the police and the lorry was eventually seized after a chase. It proved to have 41 gallons of samsu on board. The driver of the lorry was arrested at the time but two Chinese who were the real owners of the illicit samsu were not arrested. ${ }^{\text {cxcv }}$

Unlicensed toddy business also existed with the closing of toddy shops or the prohibition of sale of toddy in the estates. In one case involving labourers consuming illegal toddy, Selangor recorded the highest number. At the Raja Musa estate, Selangor, the mandores (kangani) petitioned the Resident of Selangor to permit the opening of a toddy shop there. In their petition they stated,

"We and other labourers could not drink cheap and pure toddy since 1920 due to the prohibition of toddy sales in this district. This drove us to pure or mixed toddy sold illegally. But this toddy is dangerous as there is no control and workers would drink as much as they want, it is expensive whereby one bottle is 20 cents (before prohibition, pure toddy only costs 10 cents a bottle) and this toddy is harmful to our health, as it is mixed with drugs to hasten the intoxication of drinkers."

The illegal toddy market was also wide-spread in the state of Perak. In mid-1938, the Customs Office, Larut, Taping, received a complaint on illegal sale of toddy in the area, and the police managed to apprehend 16 suspects. This case prompted the Licensing Board to cancel the business licence of a toddy contractor in the area, known as S. Rayappan, in June 1939. ${ }^{\text {cxcvii }}$ Meanwhile, in Kelantan, Malays and Tamils produced toddy at a large scale and sold them illegally in Pasir Mas and Tumpat. ${ }^{\text {cxviii }}$

The situation in Perlis was different from other states, whereby illegal toddy sales was due to British policy of total prohibition of toddy shops in the state due to the low number of labourers and demand for toddy. ${ }^{\text {cxcix }}$ The Perlis government also rejected some applications to open toddy shops in the state. A toddy contractor known as M. Munusamy, a toddy contractor at the Hamiltonia and Sarasuwatty estates in Bidor, Perak applied to the Perlis government to open a toddy shop in the state, but his application was rejected. 
A number of Indian workers in Pengkalan Asam in Perlis also applied to the Perlis Government to obtain toddy from the coconut tree for their daily use, but it too was rejected by the Perlis government. ${ }^{c c}$ In Johore, contractors misused the permit issued by government to carry out illegal toddy sales. ${ }^{\mathrm{cci}}$ The permit for tapping toddy to produce palm sugar, for instance, was misused at a large scale, while toddy tapping areas were misused for the toddy black market, whereby labourers tap toddy in excess. Other than providing toddy to licensed toddy shops, the contractor with a toddy supply licence would then sell the remaining toddy at the black market. ${ }^{\text {ccii }}$ The toddy contractor usually would order workers to tap toddy in excess, and after supplying toddy to the estate toddy shops, sell the excess toddy at the black market. This method is used to maximise profit while labourers also receive a bonus. ${ }^{\text {cciii }}$ In another case, in Wessington estate, Renggam, Johore, 77 bottles of Chinese samsu were seized from an unlicensed estate toddy shop on 19 May 1948 . $^{\text {civ }}$

In certain rural areas there is a genuine demand and that experience has shown that considerable social evils result from denying normal facilities to estate labourers who wish to drink toddy. The instruction to ration toddy to a pint per head per day in Government shops also had the effect of creating an illicit market in urban areas. The poorly-paid toddy tapper has not been slow to exploit this market both in regard to the rural visitor and the urban dweller who has not had his fill at the government shop. The use of look-out men at illegal sales centres to give warning and the legal difficulties in the way of obtaining convictions have defeated all efforts of the Customs Department to control this traffic which is wide-spread and increasing. ${ }^{\text {ccv }}$

Overall, apart from the fact that a high percentage of a labourer's wages is spent on toddy and so diverted from the purchase of necessities. This waste of income prevents labourer from improving his economic and general condition. Indulgence in toddy tends to the demoralization of the labourer and his family and to the "complete and eternal damnation of the addict". Furthermore, the Southern Indian labourer realizes that toddy drinking is an evil but is unable to resist temptation when facilities are provided even though Indians have no tradition of indulgence in alcohol.

\section{Conclusion}

This study meant a great deal in the context of Malaysian history in the colonial period, where the British used Indian labour as their 'main source' in fulfilling two goals: using them as main labour in the toddy business and encouraging them to consume toddy through the opening of toddy shops in every estates. The sale of toddy in Malaya mainly focuses in estates. No doubt the government through various rules and regulations had tried its best to curb the sale of toddy. Actually the government was motivated by a sincere desire to uplift the socioeconomic standard of toddy drinkers, who are predominantly Indians. Sad to say that this attempt has less backfired. Many of the toddy drinkers due to the inability to obtain the scarcely available toddy have resorted to other forms of alcohol which without doubt is very much more injurious to the health and wealth of the Indians as compared with toddy. Toddy taken in the proper amounts, fresh and unadulterated, is a healthy drink. It is good for the circulation of blood, for piles complaints, and has other medical value as well as, cools ones system. The government rule in curbing toddy has also resulted in the thriving of illicit toddy shops in the vicinity where toddy is legally supplied to estates. The writer hereby not means encouraging the full scale sale of toddy but what the writer suggesting is that more toddy shop should be open in areas where there is a high demand for toddy but the sale of such toddy should be limited and very closely supervised. By doing this the government can save the consumers from consuming other forms of liquor which are very detrimental to the health of the consumer and consequently the welfare of the entire family. Secondly, it can pull the rug from beneath the feet of the illicit toddy contractors and thirdly it can increase the revenue for the government.

The conclusions were reached that the sale and the consumption of toddy to Southern Indian agricultural labourers are on the following grounds:-

i. Health. Although pure or fresh toddy contains but little alcohol and is comparatively innocuous, stale or adulterated toddy may contain an excess of both directly and indirectly, as in cases of pneumonia traceable to a drunken labourer falling down and sleeping on wet ground.

ii. Economic. Labourers who are habitual toddy drinkers may spend an over large portion of their wages at toddy shop.

iii. Public Opinion. There is evidence that Indian public opinion views with concern the fact that many labourers who in India have possibly never lived within 10 miles of a toddy shop, and have never earned enough to be able to afford to drink toddy, become toddy drinkers when they come to this country, owing to the facilities offered and the higher wages earned. 


\section{END NOTES}

'CO 273/534, Memorandum, Excerpts from the "Swathesamitthiran" forwarded with Section of States F.M.S. Dispatch No.307, dated $9^{\text {th }}$ June 1926, Letter from A. Caldecott. Ag. Controller of Malaya, $27^{\text {th }}$ July 1927, p. 1.

ii Jasmin Asir, "Information Regarding Toddy Drinking" in $6^{\text {th }}$ Seminar Aaivu Kovai, India: Tamil Studies, University of Kerala, Thiruvananthapuram, 1974, pp. 370-375.

iii K. Kaliaperumal, Compendium On The Culture Of The Tamils, Ipoh: Vallalaar Association, 2008, p. 753.

iv M. Sanmugam, "Toddy in Greek and Sangam Period", in $6^{\text {th }}$ Seminar Aaivu Kovai, in 6" Seminar Aaivu Kovai, India: Tamil Studies, University of Kerala, Thiruvananthapuram, 1974, pp. 226-231.

vJasmin Asir, "Information Regarding Toddy Drinking", in $6^{\text {th }}$ Seminar AaivuKovai , pp. 370-375.

${ }^{\mathrm{vi}}$ The Indians during this period used the Thiruvalluvar calendar, based on the thinker that produced the Thirukkural containing 1330 poems.

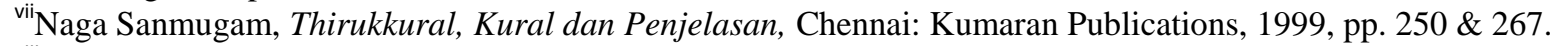

viii Jasmin Asir, "Information Regarding Toddy Drinking" in $6{ }^{\text {th }}$ Seminar Aaivu Kovai, pp. 370-375.

ix Annual Report of The Agent of The Government of India In British Malaya For The Year 1927, Calcutta: Government of India, Central Publication Branch, 1928, p. 11.

${ }^{x}$ S. Arasaratnam, Indians in Malaysia and Singapore, Kuala Lumpur: Oxford University Press, 1970, p. 70. See also, The Annual Report of The Agent of The Government of India In British Malaya For The Year 1928, Calcutta: Government of India, Central Publication Branch, 1929, p. 15.

${ }^{x i}$ K. Kalaimuthu, Malaysian Indians Towards a New Paradigm, Ipoh: A Malaysia Tamil Association, 2008, p. 213. Refer also, Azharudin Mohamed Dali, Sejarah Masyarakat India Di Malaysia, Kuala Lumpur: University of Malaya Publication, 2012, p. 230.

${ }^{x i i}$ Annual Report of The Agent of The Government of India In British Malaya For The Year 1930, Calcutta: Government of India, Central Publication Branch, 1931, p. 13.

xiii Annual Report of The Agent of The Government of India In British Malaya For The Year 1934, Delhi: Manager of Publications, 1935, pp. 13-14.

${ }^{\text {xiv }}$ Customs Toddy Shops in Ministry of Labour \& Manpower Kuala Lumpur File 1948-1962, 103/53, p. 3.

${ }^{\mathrm{xv}}$ Proceedings and Reports of the Commission of toddy in the coast district of Selangor 1917, pp. 171 \& 172. Refer also Annual Report of The Agent of The Government of India In British Malaya For The Year 1934, pp. 13-14.

${ }^{x v i}$ Petition for Toddy Shops at Klang and Port Swettenham, in the Selangor Secretariat File 287/1922, p. 1. Letter from Vaitilingan and others to Resident Selangor, Klang, $14^{\text {th }}$ January 1922.

xvii Customs Toddy Shops in the Ministry of Labour \& Manpower Kuala Lumpur File 1948-1962, 103/53. Letter from labour to Resident Commissioner Terengganu, $21^{\text {st }}$ July 1947.

${ }^{x v i i i}$ Annual Report of The Agent of The Government of India In British Malaya For The Year 1926, Calcutta: Government of India, Central Publication Branch, 1927, p. 12.

${ }^{x i x}$ The mixed and artificial toddy is impure toddy.

${ }^{\mathrm{xx}}$ Proceedings and Reports of the Commission of toddy in the coast district of Selangor 1917, pp. 339-340.

${ }^{\mathrm{xxi}}$ The explanation on Nira was given in, Toddy Committee, in the Labour Department Malaysia File 1945-1947, 426/46 \& Proceedings and Reports of the Commission of toddy in the coast district of Selangor 1917, pp. xxxiv \& 171.

${ }^{x x i i}$ This explanation found in, Estates Toddy Shops In The State of Malacca, 41/45, p. 3

xxiii Proceedings and Reports of the Commission of toddy in the coast district of Selangor 1917, p. 298.

${ }^{x x i v}$ Explanation on Era found in, Toddy Committee, in the Labour Department Malaysia File 1945-1947, 426/46.

xxv J.R. Daniel, A Socio Economic Study Of The Indians In The Rubber and Oil Palm Estates in the State of Perak and Selangor, M.A. Thesis, History Department, University of Malaya, Kuala Lumpur, 1980, pp. 106-107.

xxvi Annual Report of The Agent of The Government of India In British Malaya For The Year 1934, Delhi: Manager of Publication, 1935, pp. 14.

xxvii Proceedings and Reports of the Commission of toddy in the coast district of Selangor 1917, pp. 171.

xxviii Toddy Committee, in the Labour Department Malaysia File 1945-1947, 426/46.

${ }^{x x i x}$ Toddy Evil and the Malayan Government, in the Labour Department Malaysia File 1945-1947, 426/46, pp. 3.

${ }^{\mathrm{xxx}}$ Ibid., pp. 4-5.

${ }^{x x i}$ Ibid., pp. 5.

xxxii Toddy Committee, in the Labour Department Malaysia File 1945-1947, 426/46.

xxxiii Toddy Committee, in the Labour Department Malaysia File 1945-1947, 426/46.

xxxiv Toddy Evil and the Malayan Government, in the Labour Department Malaysia File 1945-1947, 426/46, pg. 5-7. Also see, Toddy Shop Policy, in Industrial and Social Relations, Confidential, Ministry of Labour, Kuala Lumpur 1948-1962, 103/53. 
xxxv Toddy Committee, in the Labour Department Malaysia File 1945-1947, 426/46.

xxxvi Ibid.

xxxvii Ibid.

xxxviii Ibid.

xxxix Toddy Evil and the Malayan Government, in the Labour Department Malaysia File 1945-1947, 426/46, pg. 1.

${ }^{x l}$ Toddy Committee, in the Labour Department Malaysia File 1945-1947, 426/46.

${ }^{x i i}$ Azharudin Mohd Dali, Sejarah Masyarakat India Di Malaysia, p. 243.

xlii Deva Dass, 'Alcoholism-Psycho-Social and Medical Aspects, Incident and Dangers', Seminar on Health, Food, Nutrition, Penang, $15^{\text {th }}-20^{\text {th }}$ September 1979, p. 2.

xliii The Straits Times, $2^{\text {nd }}$ February 1986.

xliv Deva Dass, 'Alcoholism-Psycho-Social and Medical Aspects, Incident and Dangers', p. 2.

${ }^{x l v}$ Toddy Policy, in Labour Department of Malaysia 1945-1947, 78/45, Toddy.

xlvi Ibid.

xlvii Ibid.

xlviii Ibid.

xlix Ibid.

I Ibid.

li Ibid.

lii Ibid.

liii Toddy is also fermented beverage in Brazil, West Africa and India. The coconut, the palymra palm, the date and the wild date all yield toddy in India, the later being grown extensively in Bengal, for the sake of the drink and the sugar extracted from it. West Africans make their toddy from "Raphia vinifera". In Brazil toddy is obtained by felling the majestic buriti, or murichi palm. See, The Toddy Tapping Industry, in Estates Toddy Shop In The State of Malacca, in Labour Department of Malacca File, 1945-1954, JBM 41/45, p. 1.

${ }^{\text {liv }}$ CO 874/881, Letter from The Government Secretary, Jesselton. Also see, CO 439/3, Federated Malay States, Selangor Administration Report ForThe Year 1922, Kuala Lumpur: The F.M.S. Government Printing Office, 1923 , p. 5.

Iv Memorandum on Toddy shops and Drunkenness by Indian Labourers, in Government Policy With Regard To Toddy, in Selangor Secretariat File, 3780/1922, p. 4. Also see, Second Supplement To The Federated Malay States Government Gazette, Vol. XIV, $9^{\text {th }}$ November 1922, p. 2050.

Ivi The Toddy Tapping Industry, in Estates Toddy Shop In The State of Malacca, in Labour Department of Malacca File, 1945-1954, JBM 41/45, p. 1-2.

Ivii Nagendralingan Ratnavadivel, 'The History of Toddy and its impact on the socio-economic sphere of the Indian especially in Selangor with particular reference to the district of Kuala Langat 1900-1973', B.A. Thesis, School of Humanities, University of Science Malaysia, Pulau Pinang, 1973/1974, p. 5.

Iviii CO 273/411, Letter from M. P. Lewis Harcourt, Colonial Office, $24^{\text {th }}$ June 1914.

lix Ibid. Also see, CO 439/3, Federated Malay States, Selangor Administration Report For The Year 1922, Kuala Lumpur: The F.M.S. Government Printing Office, 1923, p. 5; A. Paramasivam, 'Toddy Drinking in Malaysia', Presentation at Seminar on Health, Food and Nutrition, Penang, 15-20 September 1979, p. 3.

${ }^{1 x}$ CO 273/411, Letter from M. P. Lewis Harcourt, Colonial Office, $24^{\text {th }}$ June 1914. Also see, Toddy Tapping Industry, in Estates Toddy Shop In The State of Malacca, in Labour Department of Malacca, 1945-1954, JBM 41/45, p. 2; Memorandum On Toddy shops and Drunkenness by Indian Labourers, in Government Policy With Regard To Toddy, in Selangor Secretariat File, 3780/1922, p. 4; Second Supplement To The Federated Malay States Government Gazette, Vol. XIV, $9^{\text {th }}$ November 1922, p. 2057; A. Paramasivam, 'Toddy Drinking in Malaysia', p. 3.

Ixi A. Paramasivam, 'Toddy Drinking in Malaysia', p. 3.

Ixii Government Policy with regard to Toddy, in Negeri Sembilan Secretariat File, N.S.426/1925, p. 4. Also see, Toddy Tapping Industry, in Estates Toddy Shop In The State of Malacca, in Labour Department of Malacca, 1945-1954, 41/45, p. 12; Government Policy With Regard To Toddy, in Selangor Secretariat File, SEL.SEC. 3780/1922, p. 4; A. Paramasivam, 'Toddy Drinking in Malaysia', p. 3.

Ixiii Proceedings and Reports of the Commission of toddy in the coast district of Selangor 1917, p. 294.

${ }^{\text {Ixiv }}$ Government Policy with regard to Toddy, in Negeri Sembilan Secretariat File, N.S.426/1925, p. 4

Ixv Toddy Committee, in Labour Department Malaysia File, 1945-1947, 426/46. Also see, Proceedings and Reports of the Commission of toddy in the coast district of Selangor 1917, pp. xxxiv \& 171.

Ixvi Toddy Tapping Industry, in Estates Toddy Shop In The State of Malacca, in Labour Department of Malacca, 1945-1954, $41 / 45$, p. 2.

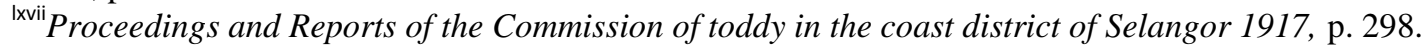


Ixviii J. R. Daniel, 'A Socio Economic Study Of The Indians In The Rubber and Oil Palm Estates in the State of Perak and Selangor', pp. 106-107.

${ }^{1 x i x}$ Annual Report of The Agent of The Government of India In British Malaya For The Year 1934, Delhi: Manager of Publication, 1935, p. 14.

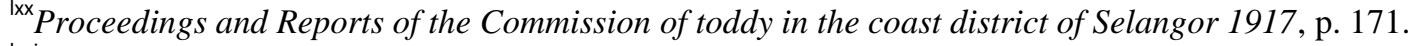

Ixxi Government's Policy With Regard To Toddy, in Selangor Secretariat File, SEL.SEC.3780/1922, p. 5. See also, Government Policy with regard to Toddy, in Negeri Sembilan Secretariat File, N.S.426/1925, p. 5.

${ }^{1 \times x i i}$ Annual Report of The Agent of The Government of India In British Malaya For The Year 1926, Calcutta: Government of India, Central Publication Branch, 1927, p. 15; \& Annual Report of The Agent of The Government of India In British Malaya For The Year 1928, Calcutta: Government of India, Central Publication Branch, 1929, p. 12.

Ixxiii Proceedings and Reports of the Commission to the alleged misuse and abuse of toddy in the coast district of Selangor 1917, p. 354. See also, The Toddy Tapping Industry, in Estates Toddy Shop In The State of Malacca, in Labour Department of Malacca, 1945-1954, JBM 41/45, p. 2. The coconut plantation used to tap toddy is shown in Appendix 2.

Ixxiv CO 439/3, Federated Malay States, Selangor Administration Report For The Year 1922, Kuala Lumpur: The F.M.S. Government Printing Office, 1923, p. 5.

Ixxv The Toddy Tapping Industry, in Estates Toddy Shop In The State of Malacca, in Labour Department of Malacca, 19451954, JBM 41/45, p. 2.

Ixxvi Ibid. Also see, Federated Malay States, Customs \& Excise Manual \& Working Instructions 1940, Kuala Lumpur: The F.M.S. Government Press, 1940, p. 230.

Ixxvii Government Toddy Contractor Malacca, in Labour Department of Malacca File, 1945-1954, JBM 18/49.

Ixxviii The Toddy Tapping Industry, in Estates Toddy Shop In The State of Malacca, in Labour Department of Malacca, 19451954, JBM 41/45, p. 2.

Ixxix Nagendralingan Ratnavadivel, 'The History of Toddy and its impact on the socio-economic sphere of the Indian especially in Selangor with particular reference to the district of Kuala Langat 1900-1973', p. 7. See also, The Toddy Tapping Industry, in Estates Toddy Shop In The State of Malacca, in Labour Department of Malacca, 1945-1954, JBM 41/45, p. 2; Public Toddy Shop in Kelantan, in British Adviser's Office Kelantan File, BAOK 833/1937, pp. 2-4.

Ixxx I. Petition from Toddy Tappers against their employer KR.SP.Subramaniam Chettiar of No.82 Main Road, Balik Pulau, II. Toddy Tappers etc. for 1955, in Labour Commissioner of Penang File, 1950-1955, PBPP 103-54.

Ixxi Government Toddy Contractor Malacca, in Labour Department of Malacca File, 1945-1954, JBM 18/49. Also see, The Toddy Tapping Industry, in Estates Toddy Shop In The State of Malacca, in Labour Department of Malacca, 1945-1954, JBM 41/45, p. 2-3.

Ixxxii The Toddy Tapping Industry, in Estates Toddy Shop In The State of Malacca, in Labour Department of Malacca, 19451954, JBM 41/45, p. 3. See also, Government Toddy Contractor, Malacca, in Labour Department of Malacca File, $1945-$ 1954, JBM 18/49.

Ixxxiii Ibid., p. 4.

${ }^{\text {Ixxiv }}$ Federated Malay States (F.M.S), Customs \& Excise Manual \& Working Instructions 1940, p. 230.

Ixxx The Toddy Tapping Industry, in Estates Toddy Shop In The State of Malacca, in Labour Department of Malacca, 19451954, JBM 41/45, p. 3. The professional tapper possesses a large curved knife, a smaller one, black-club beater for beating the shoot (in Tamil "Paalai thadura polu") and a dried coconut-bark holder to put all the above tools which tied to his waist (in Tamil "Paalai"). The costly item is the club-beater which is made in India. See, Inspection of Toddy Tapping, in Labour Department of Malacca File, 1945-1954, 31/54.

Ixxxi Ibid., p. 3.

Ixxxvii Ibid., p. 4.

Ixxvviii Ibid.

Ixxxix Ibid.

${ }^{x c}$ Ibid., p. 5.

${ }^{x c i}$ Ibid., p. 6.

xcii Ibid., pp. 4-5.

xciii Ibid., pp. 5-6.

${ }^{x c i v}$ Ibid., pp. 7-8.

${ }^{x c v}$ Ibid., p.5.

${ }^{x c v i}$ Nagendralingan Ratnavadivel, 'The History of Toddy and its impact on the socio-economic sphere of the Indian especially in Selangor with particular reference to the district of Kuala Langat 1900-1973', p. 5.

xcvii The Toddy Tapping Industry, in Estates Toddy Shop In The State of Malacca, in Labour Department of Malacca, 19451954, JBM 41/45, p. 3. Also see, Toddy Yields, in Department of Customs \& Excise Batu Pahat, 1945-1970, CEJ 1029. 
xcviii Ibid. Also see, CO 273/411, Letter from M. P. Lewis Harcourt, Colonial Office, $24^{\text {th }}$ June 1914. See the process of toddy collection in Appendix 1.

${ }^{x c i x}$ Ibid. Also see, Bekalan Tuak Borongan Ke-Atas Kedai Tuak Kerajaan Johore Baharu (1965-1966), 1948-1970, in Department of Customs \& Excise Batu Pahat, 1945-1970, KEJ 2090/Jil V; Government Toddy Contractor Malacca, in Labour Department of Malacca, 1945-1954, JBM 18/49.

${ }^{\mathrm{c}} \mathrm{CO}$ 273/410, Letter From Government House, Singapore, April 1914.

${ }^{c i}$ CO 439/3, Federated Malay States, Selangor Administration Report For The Year 1922, Kuala Lumpur: The F.M.S. Government Printing Office, 1923, p. 5. Also see, Estate Toddy Shop (Retail), in District Office of Muar File, 1947-1961, MLB 7/55.

cii Nagendralingan Ratnavadivel, 'The History of Toddy and its impact on the socio-economic sphere of the Indian especially in Selangor with particular reference to the district of Kuala Langat 1900-1973', p.7

ciii The Toddy Tapping Industry, in Estates Toddy Shop In The State of Malacca, in Labour Department of Malacca, 19451954, JBM 41/45, p.4. Also see, Annual Report of The Agent of The Government of India In British Malaya For The Year 1930, Calcutta: Government of India, Central Publication Branch, 1931, p. 13.

civ Toddy Committee, in the Labour Department Malaysia File 1945-1947, 426/46.

${ }^{\mathrm{cv}}$ Toddy Farm for 1901-Tenders for, in Selangor Secretariat File 7414/1900. Letter from District Officer to Resident of Selangor, Ulu Langat, $17^{\text {th }}$ December 1900.

cvi The Toddy Tapping Industry, in Estates Toddy Shop In The State of Malacca, in Labour Department of Malacca, 19451954, JBM 41/45, p. 10.

cvii Government policy with regard to Toddy, in Selangor Secretariat File, SEL.SEC.3780/1922, p. 10. Also see, CO 273/563, Report by the Superintendent, Government Monopolies, Straits Settlements, dated $16^{\text {th }}$ September 1929, Letter from G. Gordon Wilson, Superintendent, Government Monopolies, Straits Settlements, p. 1; CO 439/3, Federated Malay States, Selangor Administration Report For The Year 1922, Kuala Lumpur: The F.M.S. Government Printing Office, 1923, p. 5.

cviii The Toddy Tapping Industry, in Estates Toddy Shop In The State of Malacca, in Labour Department of Malacca, 19451954, JBM 41/45, pp. 10-11. See also, Toddy Committee, in Labour Department Malaysia File, 1945-1947, 426/46. Letter from Sgd. W.J.K.Stark, Malayan Representative in India to Office of the Malayan Representative in India, $24^{\text {th }}$ April 1947.

${ }^{c i x}$ CO 273/563, Letter from Governor's Deputy to Colonial Office, Straits Settlements, $23^{\text {rd }}$ June 1930, p. 1.

${ }^{c x}$ The Toddy Tapping Industry, in Estates Toddy Shop In The State of Malacca, in Labour Department of Malacca, 19451954, JBM 41/45, p. 11.

${ }^{c \times i}$ CO 273/500, Annual Report of The Straits Settlements For The Year 1919, p. 32.

cxii CO 273/563, Letter from Governor's Deputy to Colonial Office, Straits Settlements, $23^{\text {rd }}$ June 1930, p. 1; CO 273/399, Letter from M. P. Lewis Harcourt, Government House, Singapore, April 1913; Federated Malay States, Government Gazette, Vol. XXIV, Kuala Lumpur: Published by Authority, $4^{\text {th }}$ November 1932, p. vi.

cxiii The Toddy Tapping Industry, in Estates Toddy Shop In The State of Malacca, in Labour Department of Malacca, 19451954, JBM 41/45, pp. 11-12.

${ }^{\text {cxiv }}$ The payment of this amount varies according to state. For example in Kedah, the amount was $\$ 50$, and in Selangor it was $\$ 100$. See, Toddy Contacts For 1952, in Kedah Secretariat File, 36/71 \& Toddy Shop Licenses of 1913, in Selangor Secretariat File, 3932/1912.

${ }^{c \times v}$ Federated Malay States, Government Gazette, Vol. XXIV, Kuala Lumpur: Published by Authority, $4^{\text {th }}$ November 1932 \& Federated Malay States, Government Gazette, Vol. XVII, Kuala Lumpur: Published by Authority, $16^{\text {th }}$ October 1925 . Also see, CO 273/399, Letter from M. P. Lewis Harcourt, Government House, Singapore, April 1913; Toddy Farm for 1901 Tenders for, in Selangor Secretariat File 7414/1900. Letter from District Officer to Resident Selangor, Ulu Langat, 17th December 1900; Karthiayini Katigason, 'Todi Dalam Kalangan Masyarakat India Ladang Di Selangor, 1890-1945', M.A. Dissertation, Department of History, University of Malaya, Kuala Lumpur, 2010/2011, pp. 86-87.

cxvi The Toddy Tapping Industry, in Estates Toddy Shop In The State of Malacca, in Labour Department of Malacca, 19451954, JBM 41/45, p. 12. See also, Federated Malay States, Government Gazette, Vol. XVI, Kuala Lumpur: Published by Authority, $22^{\text {nd }}$ February 1924, p. vi; Laws of the F.M.S. Cap. 133 Excise Ordinance Toddy Shops On Estate in Kedah, in Attorney General's Chambers Files, 1957, JPN 1210. Report J. Grundy, Commissioner for Labour, Federation of Malaya, Federal House, Kuala Lumpur, $6^{\text {th }}$ August 1957.

cxvii Ibid., p.12.

cxviii Ibid., pp. 12-13.

${ }^{\text {cxix }}$ Ibid., p.13.

${ }^{c x x}$ Resolution passed at a meeting of the Planter's Association Of Malaya held on the Toddy Commissioner \& Committee, in High Commissioner Office File, HCO 1544/1917. Letter from Chief Secretary, Kuala Lumpur, $19^{\text {th }}$ September 1917.

${ }^{c x x i}$ The Toddy Tapping Industry, in Estates Toddy Shop In The State of Malacca, in Labour Department of Malacca, 19451954, JBM 41/45, p.13. 


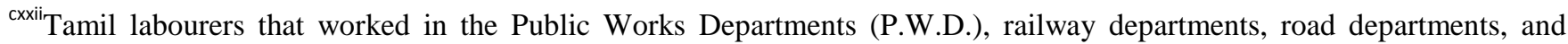
mines were the largest toddy customers in the town area. This was because they too carry out hard labour as the estate workers, and spend more energy as a result. See, Applying for a licence to open a toddy shop at Senggarang, in Land Office of Batu Pahat File, 1914-1931, AABP 173/23.

cxxii Illicit samsu. Speeches by the Honourable Mr.B.J.R.Barton, State Council 24.9.35, in Ministry of Johore File, 1933-1936, MBJ 371/35; Also see, 'Illicit Samsu: Second Offenders Should Be Punished', Malaya Tribune, 25 September 1935.

cxxiv Toddy Shop Policy, in Industrial and Social Relations, Confidential, Ministry of Labour, Kuala Lumpur 1948-1962, $103 / 53$.

${ }^{c x x v}$ In this study, the Straits Settlements (SS) refer to Penang and Malacca. The Federated Malay States (FMS) covers Perak, Selangor, Negeri Sembilan, and Pahang. The Unfederated Malay States (UFMS) refer to Kedah, Perlis, Kelantan, Terengganu, and Johore. See, CO 273/563, Letter from Governor's Deputy to Colonial Office, Straits Settlements, $23^{\text {rd }}$ June 1930 , p. 1.

${ }^{\mathrm{cxxvi}}$ Annual Report of The Agent of The Government of India In British Malaya For The Year 1926, Calcutta: Government of India, Central Publication Branch, 1927, p. 12.

${ }^{c x x v i i}$ Federation of Malaya, Annual Report of The Labour Department For The Year 1956, Kuala Lumpur: The Government Press, 1957, p. 33 \& Federation of Malaya, Annual Report of The Labour Department For The Year 1954, Kuala Lumpur: The Government Press, 1955, p. 42.

${ }^{c x x v i i i}$ CO 437/3, Pahang Administration Report For The Year 1931, Kuala Lumpur: The F.M.S. Government Printing Office, 1932, p. 26.

${ }^{\text {cxxix }} \mathrm{S}$. Arasaratnam, Indians in Malaysia and Singapore, p. 70.

${ }^{\mathrm{cxx}} \mathrm{CO}$ 439/3, Federated Malay States, Selangor Administration Report For The Year 1910, Kuala Lumpur: The F.M.S. Government Printing Office, 1911, p. 14.

${ }^{\mathrm{cxxi}} \mathrm{CO}$ 439/3, Federated Malay States, Selangor Administration Report For The Year 1911, Kuala Lumpur: The F.M.S. Government Printing Office, 1912, p. 9.

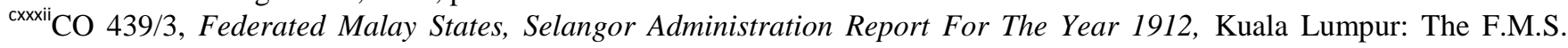
Government Printing Office, 1913, pp. 9-10.

cxxiii CO 438/4, Federated Malay States, Perak Administration Report For The Year 1918, Kuala Lumpur: The F.M.S. Government Printing Office, 1919, pp. 3-5.

${ }^{\text {cxxiv }}$ CO 439/3, Federated Malay States, Selangor Administration Report For The Year 1913, Kuala Lumpur: The F.M.S. Government Printing Office, 1914, p. 10.

${ }^{\mathrm{cxxxv}} \mathrm{CO}$ 439/3, Federated Malay States, Selangor Administration Report For The Year 1914, Kuala Lumpur: The F.M.S. Government Printing Office, 1915, p. 11 \& Federated Malay States, Selangor Administration Report For The Year 1915, Kuala Lumpur: The F.M.S. Government Printing Office, 1916, p. 12.

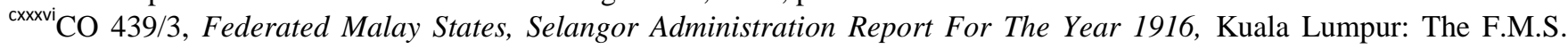
Government Printing Office, 1917, p. 10; Federated Malay States, Selangor Administration Report For The Year 1917, Kuala Lumpur: The F.M.S. Government Printing Office, 1918, p. 6.

cxxxvii Tenders for Toddy Shop in Kuala Selangor District for 1917, Recommendations acceptance, in Selangor Secretariat File, 5970/1916. Letter from District Officer of Kuala Selangor to Resident Selangor, Kuala Selangor, $11^{\text {th }}$ December 1916.

cxxxviii CO 439/3, Federated Malay States, Selangor Administration Report For The Year 1917, Kuala Lumpur: The F.M.S. Government Printing Office, 1918, p. 6; Licensing of Toddy Shop in Kuala Lumpur District, in Selangor Secretariat File, 5086/1916. Letter from Chairman, Selangor Licensing Board to Resident Selangor, Kuala Lumpur, $25^{\text {th }}$ October 1916.

${ }^{\text {cxxix }}$ CO 273/563, Report by the Superintendent, Government Monopolies, Straits Settlements, dated $16^{\text {th }}$ September 1929 , p. 1.

cxl Restriction and Additions under which toddy shops license issued to Estate Manager with F.M.S Enquires as to, in Selangor Secretariat File 3913/1920, Kuala Lumpur, $27^{\text {th }}$ July 1920.

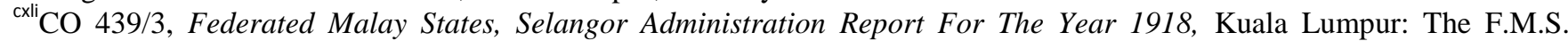
Government Printing Office, 1919, p. 8.

cxlii CO 439/3, Federated Malay States, Selangor Administration Report For The Year 1919, Kuala Lumpur: The F.M.S. Government Printing Office, 1920, p. 14.

cxliii CO 439/3, Federated Malay States, Selangor Administration Report For The Year 1922, Kuala Lumpur: The F.M.S. Government Printing Office, 1923, p. 5.

cxliv Government Policy as to toddy shop in Kuala Langat, in Selangor Secretariat File, 511/1923, p. 3.

${ }^{c x l v}$ Government Policy as to sale of toddy in Ulu Langat District, in Selangor Secretariat File, 337/1923, p. 1.

${ }^{c x l v i}$ Annual Report of The Labour Department For The Three Inland Districts of Selangor For The Year 1920, in Selangor Secretariat File 1025/1921, p. 6. 
cxlvii Estate Toddy Shop Jenderata Estate, in Customs \& Excise Department, Telok Anson, Perak, File1942-1956, JKEDP 312/52.

cxlviii CO 438/5, Federated Malay States, Perak Administration Report For The Year 1931, Kuala Lumpur: The F.M.S. Government Printing Office, 1932, p. 44; CO 438/5, Federated Malay States, Annual Report On The Social and Economic Progress of The People of Perak For The Year 1934, Kuala Lumpur: The F.M.S. Government Press, 1935 , p. 71.

${ }^{c x l i x}$ CO 438/5, Federated Malay States, Annual Report On The Social and Economic Progress of The People of Perak For The Year 1935, Kuala Lumpur: The F.M.S. Government Press, 1936, p. 98.

${ }^{c l}$ CO 438/5, Federated Malay States, Annual Report On The Social and Economic Progress of The People of Perak For The Year 1936, Kuala Lumpur: The F.M.S. Government Press, 1937, p. 103.

${ }^{c l i}$ CO 438/5, Federated Malay States, Annual Report On The Social and Economic Progress of The People of Perak For The Year 1937, Kuala Lumpur: The F.M.S. Government Press, 1938, p. 114.

${ }^{c l i i}$ Federated Malay States, Annual Report On The Social and Economic Progress of The People of Perak For The Year 1933, Kuala Lumpur: The F.M.S. Government Press, 1934, p. 63.

cliii Annual Report of The Agent of The Government of India In British Malaya For The Year 1935, Delhi: Manager of Publication, 1936, p. 36.

cliv CO 273/563, Report by the Superintendent, Government Monopolies, Straits Settlements, dated $16^{\text {th }}$ September 1929 , Letter from G. Gordon Wilson, Superintendent, Government Monopolies, Straits Settlements, p. 1.

clv Ibid.

clvi Supply of Toddy in Penang \& Province Wellesley, in Pulau Pinang Secretariat File, RCP/CUST/1018/1948.

clvii Toddy Committee, Labour Department of Malaysia File, 1945-1947, LDM 426/46. Letter from Jas Grundy, Commissioner For Labour, Kedah \& Perlis, Sungai Petani to The Hon'ble the British Adviser, Kedah, Alor Setar.

${ }^{c l v i i}$ Annual Report On The Social and Economic Progress of The People of The State of Kedah For The Year 1355 A.H.\&1356 A.H., Alor Setar: The Kedah Government Press, 1937 \& 1938.

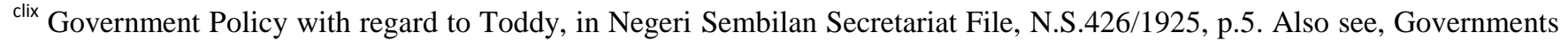
Policy with Regard to Toddy Forward Pamphlet entitled, in Negeri Sembilan Secretariat File 2299/1922, p. 5.

clx Ibid.

${ }^{c 1 x i}$ Proceedings and Reports of the Commission to the alleged misuse and abuse of toddy in the coast district of Selangor 1917, pp. 281-282. Letter from, R. D. Greenhill, The Highlands and Lowlands Para Rubber Co., Ltd. (England), Highlands Estate to The Licensing Officer, Klang, $27^{\text {th }}$ July 1915.

${ }^{c x i i}$ Reports against Kathamuthu Naiker who holds a licence (wholesale) to deal in toddy, in Land Office of Batu Pahat, 1931 1946, AABP 117/33. Letter from Supt. Prev. Branch to The Asst: Adviser, Batu Pahat, $10^{\text {th }}$ May 1933.

cliii Power of Licensing Board to Restrict the hours of sale in the case of a) public house licence, b) toddy shop, in Customs Department of State of Kelantan File, 1946-1962, JKDNK 200/54.

${ }^{\text {clxiv }}$ Increase in toddy drinking amongst certain sections of the Indian community in Malaya. Forwards of S.S. \& F.M.S despt: re asks for reports, British Adviser's Office Kelantan File, BAOK 540/1930.

${ }^{\mathrm{clxv}}$ Annual Report of The Agent of The Government of India In British Malaya For The Year 1928, Calcutta: Government of India, Central Publication Branch, 1929, p. 14.

clxvi Memorandum on Toddy Shops of Estates in particular and Kelantan in general, in Report of The Estate Toddy Shop Committee, in Kelantan Secretariat File, 296/1947, p. 1. Also see, Licences to the managers of Estates to supply Toddy to the Tamil Coolies on their estates, British Adviser's Office Kelantan File, BAOK 729/1916. Letter from C. H. Miller, Ag. Manager, The Central Kelantan Rubber Company Limited to The District Officer, Ulu Kelantan, $25^{\text {th }}$ October 1916.

clxvii Federation of Malaya, Annual Report For The Year 1949, Kuala Lumpur: The Government Press, 1950, p. 49. Also see, Excise Rules: Rules concerning toddy shops, in Trengganu Legal Advisor's Office File, 1932-1962, PPUT 71/1946.

${ }^{c 1 x v i i i}$ Annual Report on The Social and Economic Progress of The People of The State of Trengganu (Unfederated Malay States) 1938, London: Published By His Majesty's Stationery Office, 1939, p. 34. See also, Toddy Shops for Jabor Valley Estate, in British Adviser's Office Terengganu File, BAOT 1038/1936.

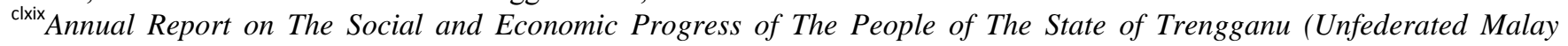
States) 1935,London: Published By His Majesty's Stationery Office, 1936, p. 25.

${ }^{\mathrm{c} x \mathrm{x}}$ Annual Report on The Social and Economic Progress of The People of The State of Trengganu (Unfederated Malay States) 1937,London: Published By His Majesty's Stationery Office, 1938, p. 33.

${ }^{c 1 x x i}$ Federation of Malaya, Annual Report For The Year 1949,p. 49.

${ }^{c}$ xxii Annual Report of The Agent of The Government of India In British Malaya For The Year 1928, Calcutta: Government of India, Central Publication Branch, 1929, p. 14. Also see, Federated Malay States, Annual Report on The Social and Economic Progress of The People of Pahang For The Year 1937, Kuala Lumpur: The F.M.S. Government Press, 1938; Federated Malay States, Annual Report On The Social and Economic Progress of The People of Pahang For The Year 1938, Kuala Lumpur: The F.M.S. Government Press, 1939. 
clxxiii Estate Toddy Shops, in Perlis Secretariat File, 374. Letter from D. K. Daniels to Headquarters, British Military Administration, Malay Peninsula, KL, $17^{\text {th }}$ December 1945.

clxxiv Memorandum on The Question of The Re-opening of Estate Toddy Shops In Kedah \& Perlis, in Kedah Secretariat File, 228/46.

${ }^{c l x x v}$ Estates Toddy Shop In The State of Malacca, in Labour Department of Malacca File, 1945-1954, JBM 41/45, p. 1.

clxxvi Nagendralingan Ratnavadivel, 'The History of Toddy and its impact on the socio-economic sphere of the Indian especially in Selangor with particular reference to the district of Kuala Langat 1900-1973', p. 38.

clxxvii Customs Toddy Shops, in Ministry of Labour and Manpower File, Kuala Lumpur, 1948-1962, KBTRKL 103/53, p. 2.

clxxviii Miscellaneous B.M.A. Correspondence, in District Office Pekan, Pahang File, 1945-1966, PDP 3/1946.

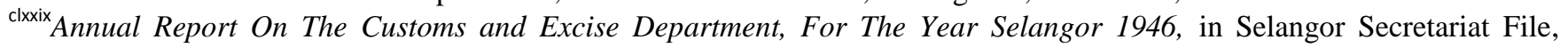
R.C.SELANGOR 275/1947, p. 2.

${ }^{\mathrm{c} x \times x}$ Annual Report of The Customs and Excise Department, Selangor For The Year 1943, in Selangor Secretariat File, Syuseityo Kanbo 117/2603 (1943), pp. 3-4

${ }^{c \mid l x x i}$ Tender for the supply of toddy to Government toddy shops during 1946, in Kedah Secretariat File, 284.

clxxxii Annual Report On The Customs and Excise Department, For The Year Selangor 1946, in Selangor Secretariat File, R.C.SELANGOR 275/1947, p. 2-3.

clxxxiii Report of The Estate Toddy Shops Committee, in Labour Department of Malaysia File, 1945-1947, LDM 426/46 pt. ii, p. 3.

clxxxiv Toddy Evil and the Malayan Government, in the Labour Department Malaysia File 1945-1947, 426/46, p. 3.

clkxxv Report of The Estate Toddy Shops Committee, in Labour Department of Malaysia File, 1945-1947, LDM 426/46 pt. ii, p. 3.

clxxxvi The United Planting Association of Malaya: Toddy Shops, in Labour Department of Malaysia File, 1945-1947, LDM $426 / 46$.

clxxvvii CO 273/411, Letter from M. P. Lewis Harcourt, Colonial Office, 24 ${ }^{\text {th }}$ June 1914.

clxxviii Illicit samsu. Speeches by the Honourable Mr. B.J.R.Barton, State Council 24.9.35, Ministry of Johore File, 1933-1936, MBJ 371/35. See also, 'Illicit Samsu: Second Offenders Should Be Punished', Malaya Tribune, 25 September 1935.

clxxxix CO 273/563, Report by the Superintendent, Government Monopolies, Straits Settlements, dated $16^{\text {th }}$ September 1929 , Letter from G. Gordon Wilson, Superintendent, Government Monopolies, Straits Settlements, p. 1.

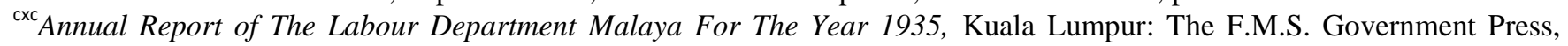
1936, p. 46.

${ }^{c x i}$ Federated Malay States, Report on The Customs and Excise Department For The Year 1936, Kuala Lumpur: The F.M.S. Government Press, 1937, p. 25.

cxcii Federated Malay States, Report on The Customs and Excise Department For The Year 1938, Kuala Lumpur: The F.M.S. Government Press, 1939, pp. 24-25.

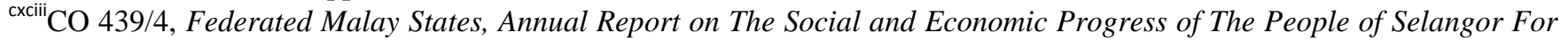
The Year 1938, Kuala Lumpur: The F.M.S. Government Press, 1939, p. 53. Also see, Federated Malay States, Report on The Customs and Excise Department For The Year 1938, Kuala Lumpur: The F.M.S. Government Press, 1939, pp. 25-26.

${ }^{c x c i v}$ Ibid. Also see, Federated Malay States, Report on The Customs and Excise Department For The Year 1936, Kuala Lumpur: The F.M.S. Government Press, 1937, p. 25.

${ }^{\mathrm{cxc}}$ Federated Malay States, Report on The Customs and Excise Department For The Year 1938, Kuala Lumpur: The F.M.S. Government Press, 1939, p. 26.

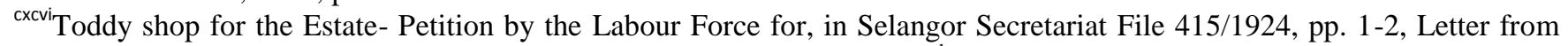
Mandor-mandor, Raja Musa Estate, Kuala Selangor to Resident British, $17^{\text {th }}$ January 1924.

cxcvii Toddy Supplier (S.Rayappan) Delivering excess toddy after the usual daily supply, in District Office of Larut \& Matang, Perak, 1926-1939, PDLM 300/39.

cxcviii Complaints that many people (Malays \& Tamils) are infringing his rights by manufacturing \& selling toddy \& asks that, if they are arrested, all fines imposed on them be given to him, in British Adviser's Office Kelantan File, BAOK 1052/1927, pp. 1-2.

${ }_{\text {cxcix }}$ Increase in the selling price of toddy, in Perlis Secretariat File, 806.

${ }^{c c}$ Permission to distil Toddy from the coconut trees, for their own consumption, Perlis Secretariat File, BMAP 196. Letter from Indian Labour, Bukit Lagi District, Kangar toThe Civil Affairs Officer, Perlis, 1th March 1946.

${ }^{c c i}$ Sale of Liquor to South Indian labourers, in District Office of Klang File, 1939-1961, PDK 517/49.

ccii Illegal Sale of Toddy, District Office Johor Bahru File, 1948-1974, DOJB 632/52. Memorandum from Deputy Commissioner for Labour, Johore, $17^{\text {th }}$ August 1952.

cciii Illegal Sale of Toddy, in District Office of Muar, 1943-1972, PDM 125/52. 
${ }^{\text {cciv }}$ Illicit Sale of Chandu \& Samsu in Central Johore, in Department of Customs \& Excise Batu Pahat File, 1945-1970, CEJ 351 .

${ }^{\text {ccv }}$ Customs Toddy Shops, in Ministry of Labour Kuala Lumpur 1948-1962, 103/53.

\section{BIBLIOGRAPHY}

\section{Primary Sources}

\section{Archive Files (National Archive of Kuala Lumpur and other archives of Malaysia)} Colonial Office Records

CO 273/399, Letter from M. P. Lewis Harcourt, Government House, Singapore, April 1913.

CO 273/410, Letter from Government House, Singapore, April 1914.

CO 273/411, Letter from M. P. Lewis Harcourt, Colonial Office, $24^{\text {th }}$ June 1914.

CO 273/500, Annual Report of The Straits Settlements For The Year 1919.

CO 273/534, Memorandum, Excerpts from the "Swathesamitthiran" forwarded with Section of States F.M.S. Dispatch No.307, dated $9^{\text {th }}$ June 1926, Letter from A. Caldecott. Ag. Controller of Malaya, $27^{\text {th }}$ July 1927.

CO 273/563, Report by the Superintendent, Government Monopolies, Straits Settlements, dated $16^{\text {th }}$ September 1929 , Letter from G. Gordon Wilson, Superintendent, Government Monopolies, Straits Settlements.

CO 273/563, Letter from Governor's Deputy to Colonial Office, Straits Settlements, $23^{\text {rd }}$ June 1930.

CO 439/3, Federated Malay States, Selangor Administration Report For The Year 1910, Kuala Lumpur: The F.M.S. Government Printing Office, 1911.

CO 439/3, Federated Malay States, Selangor Administration Report For The Year 1911, Kuala Lumpur: The F.M.S. Government Printing Office, 1912.

CO 439/3, Federated Malay States, Selangor Administration Report For The Year 1912, Kuala Lumpur: The F.M.S. Government Printing Office, 1913.

CO 438/4, Federated Malay States, Perak Administration Report For The Year 1918, Kuala Lumpur: The F.M.S. Government Printing Office, 1919.

CO 439/3, Federated Malay States, Selangor Administration Report For The Year 1913, Kuala Lumpur: The F.M.S. Government Printing Office, 1914.

CO 439/3, Federated Malay States, Selangor Administration Report For The Year 1914, Kuala Lumpur: The F.M.S. Government Printing Office, 1915.

Federated Malay States, Selangor Administration Report For The Year 1915, Kuala Lumpur: The F.M.S. Government Printing Office, 1916.

CO 439/3, Federated Malay States, Selangor Administration Report For The Year 1916, Kuala Lumpur: The F.M.S. Government Printing Office, 1917.

CO 439/3, Federated Malay States, Selangor Administration Report For The Year 1917, Kuala Lumpur: The F.M.S. Government Printing Office, 1918.

CO 439/3, Federated Malay States, Selangor Administration Report For The Year 1918, Kuala Lumpur: The F.M.S. Government Printing Office, 1919.

CO 439/3, Federated Malay States, Selangor Administration Report For The Year 1919, Kuala Lumpur: The F.M.S. Government Printing Office, 1920.

CO 439/3, Federated Malay States, Selangor Administration Report For The Year 1922, Kuala Lumpur: The F.M.S. Government Printing Office, 1923.

CO 438/5, Federated Malay States, Perak Administration Report For The Year 1931, Kuala Lumpur: The F.M.S. Government Printing Office, 1932.

CO 439/4, Federated Malay States, Annual Report On The Social and Economic Progress of The People of Selangor For The Year 1934, Kuala Lumpur: The F.M.S. Government Press, 1935.

CO 439/4, Federated Malay States, Annual Report On The Social and Economic Progress of The People of Selangor For The Year 1935, Kuala Lumpur: The F.M.S. Government Press, 1936.

CO 439/4, Federated Malay States, Annual Report On The Social and Economic Progress of The People of Selangor For The Year 1936, Kuala Lumpur: The F.M.S. Government Press, 1937.

CO 439/4, Federated Malay States, Annual Report On The Social and Economic Progress of The People of Selangor For The Year 1937, Kuala Lumpur: The F.M.S. Government Press, 1938.

CO 439/4, Federated Malay States, Annual Report On The Social and Economic Progress of The People of Selangor For The Year 1938, Kuala Lumpur: The F.M.S. Government Press, 1939.

CO 439/4, Federated Malay States, Annual Report On The Social and Economic Progress of The People of Selangor For The Year 1939, Kuala Lumpur: The F.M.S. Government Press, 1940.

CO 874/881, Letter from The Government Secretary, Jesselton. 


\section{Annual Reports}

Annual Report of The Agent of The Government of India In British Malaya For The Year 1926, Calcutta: Government of India, Central Publication Branch, 1927.

Annual Report of The Agent of The Government of India In British Malaya For The Year 1927, Calcutta: Government of India, Central Publication Branch, 1928.

Annual Report of The Agent of The Government of India In British Malaya For The Year 1928, Calcutta: Government of India, Central Publication Branch, 1929.

Annual Report of The Agent of The Government of India In British Malaya For The Year 1929, Calcutta: Government of India, Central Publication Branch, 1930.

Annual Report of The Agent of The Government of India In British Malaya For The Year 1930, Calcutta: Government of India, Central Publication Branch, 1931.

Annual Report of The Agent of The Government of India In British Malaya For The Year 1931, Calcutta: Government of India, Central Publication Branch, 1932.

Annual Report of The Agent of The Government of India In British Malaya For The Year 1932, Calcutta: Government of India, Central Publication Branch, 1933.

Annual Report of The Agent of The Government of India In British Malaya For The Year 1933, Calcutta: Government of India, Central Publication Branch, 1934.

Annual Report of The Agent of The Government of India In British Malaya For The Year 1934, Delhi: Manager of Publication, 1935.

Annual Report of The Agent of The Government of India In British Malaya For The Year 1935, Delhi: Manager of Publication, 1936.

Annual Report of The Labour Department Malaya For The Year 1935, Kuala Lumpur: The F.M.S. Government Press, 1936.

Annual Report of The Labour Department For The Three Inland Districts of Selangor For The Year 1920.

Annual Report On The Social and Economic Progress of The People of The State of Kedah For The Year 1355 A.H.\&1356 A.H., Alor Setar: The Kedah Government Press, 1937 \& 1938.

Annual Report on The Social and Economic Progress of The People of The State of Trengganu (Unfederated Malay States) 1935, London: Published By His Majesty's Stationery Office, 1936.

Annual Report on The Social and Economic Progress of The People of The State of Trengganu (Unfederated Malay States) 1937, London: Published By His Majesty's Stationery Office, 1938.

Annual Report on The Social and Economic Progress of The People of The State of Trengganu (Unfederated Malay States) 1938, London: Published By His Majesty's Stationery Office, 1939.

Federated Malay States, Annual Report on The Social and Economic Progress of The People of Pahang For The Year 1937, Kuala Lumpur: The F.M.S. Government Press, 1938.

Federated Malay States, Annual Report On The Social and Economic Progress of The People of Pahang For The Year 1938, Kuala Lumpur: The F.M.S. Government Press, 1939.

Federated Malay States, Annual Report On The Social and Economic Progress of The People of Perak For The Year 1933, Kuala Lumpur: The F.M.S. Government Press, 1934.

Federated Malay States, Annual Report On The Social and Economic Progress of The People of Perak For The Year 1934, Kuala Lumpur: The F.M.S. Government Press, 1935.

Federated Malay States, Annual Report On The Social and Economic Progress of The People of Perak For The Year 1935, Kuala Lumpur: The F.M.S. Government Press, 1936.

Federated Malay States, Annual Report On The Social and Economic Progress of The People of Perak For The Year 1936, Kuala Lumpur: The F.M.S. Government Press, 1937.

Federated Malay States, Annual Report On The Social and Economic Progress of The People of Perak For The Year 1937, Kuala Lumpur: The F.M.S. Government Press, 1938.

Federated Malay States, Annual Report On The Social and Economic Progress of The People of Perak For The Year 1938, Kuala Lumpur: The F.M.S. Government Press, 1939.

Federated Malay States, Annual Report On The Social and Economic Progress of The People of Perak For The Year 1939, Kuala Lumpur: The F.M.S. Government Printing Office, 1940.

Federated Malay States, Perak Administration Report For The Year 1925, Kuala Lumpur: The F.M.S. Government Printing Office, 1926.

Federated Malay States, Perak Administration Report For The Year 1926, Kuala Lumpur: The F.M.S. Government Printing Office, 1927.

Federated Malay States, Perak Administration Report For The Year 1927, Kuala Lumpur: The F.M.S. Government printing Office, 1928.

Federated Malay States, Perak Administration Report For The Year 1928, Kuala Lumpur: F.M.S. Government Printing Office, 1929. 
Federated Malay States, Perak Administration Report For The Year 1931, Kuala Lumpur: The F.M.S. Government Printing Office, 1932.

Federated Malay States, Perak Administration Report For The Year 1932, Kuala Lumpur: The F.M.S. Government Printing Office, 1933.

Federated Malay States, Perak Administration Report For The Year 1939, Kuala Lumpur: The F.M.S. Government printing Office, 1940.

Federated Malay States, Annual Report On The Social \& Economic Progress of The People of Selangor For The Year 1931, Kuala Lumpur: The F.M.S. Government Press, 1932.

Federated Malay States, Annual Report On The Social \& Economic Progress of The People of Selangor For The Year 1932, Kuala Lumpur: The F.M.S. Government Press, 1933.

Federated Malay States, Annual Report On The Social \& Economic Progress of The People of Selangor For The Year 1933, Kuala Lumpur: The F.M.S. Government Press, 1934.

Federated Malay States, Annual Report On The Social \& Economic Progress of The People of Selangor For The Year 1934, Kuala Lumpur: The F.M.S. Government Press, 1935.

Federated Malay States, Annual Report On The Social \& Economic Progress of The People of Selangor For The Year 1935, Kuala Lumpur: The F.M.S. Government Press, 1936.

Federated Malay States, Annual Report On The Social \& Economic Progress of The People of Selangor For The Year 1936, Kuala Lumpur: The F.M.S. Government Press, 1937.

Federated Malay States, Annual Report On The Social \& Economic Progress of The People of Selangor For The Year 1937, Kuala Lumpur: The F.M.S. Government Press, 1938.

Federated Malay States, Annual Report On The Social \& Economic Progress of The People of Selangor For The Year 1938, Kuala Lumpur: The F.M.S. Government Press, 1939.

Federated Malay States, Annual Report On The Social \& Economic Progress of The People of Selangor For The Year 1939, Kuala Lumpur: The F.M.S. Government Press, 1940.

Federated Malay States, Customs \& Excise Manual \& Working Instructions 1940, Kuala Lumpur: The F.M.S. Government Press, 1940.

Federated Malay States, Report on The Customs and Excise Department For The Year 1936, Kuala Lumpur: The F.M.S. Government Press, 1937.

Federated Malay States, Report on The Customs and Excise Department For The Year 1938, Kuala Lumpur: The F.M.S. Government Press, 1939.

Federated Malay States, Selangor Administration Report For The Year 1915, Kuala Lumpur: The F.M.S. Government Printing Office, 1916.

Federated Malay States, Selangor Administration Report For The Year 1917, Kuala Lumpur: The F.M.S. Government Printing Office, 1918.

Federation of Malaya, Annual Report For The Year 1949, Kuala Lumpur: The Government Press, 1950.

Federation of Malaya, Annual Report of The Labour Department For The Year 1954, Kuala Lumpur: The Government Press, 1955.

Federation of Malaya, Annual Report of The Labour Department For The Year 1956, Kuala Lumpur: The Government Press, 1957.

Proceedings and Reports of the Commission, Appointed to inquire into certain matters affecting the good government of the state of Selangor in relation to the alleged misuse and abuse of toddy in the coast district of Selangor 1917, Kuala Lumpur: Federated Malay States Government Press, 1917.

\section{Government Gazette}

Federated Malay States, Second Supplement To The Federated Malay States Government Gazette, Vol. XIV, ${ }^{\text {th }}$ November 1922.

Federated Malay States, Government Gazette, Vol. XVI, Kuala Lumpur: Published by Authority, $22^{\text {nd }}$ February 1924.

Federated Malay States, Government Gazette, Vol. XVII, Kuala Lumpur: Published by Authority, $16^{\text {th }}$ October 1925.

Federated Malay States, Government Gazette, Vol. XXIV, Kuala Lumpur: Published by Authority, $4^{\text {th }}$ November 1932.

\section{High Commissioner Office}

Resolution passed at a meeting of the Planter's Association Of Malaya held on the Toddy Commissioner \& Committee, in High Commissioner Office File, HCO 1544/1917. Letter from Chief Secretary, Kuala Lumpur, $19^{\text {th }}$ September 1917.

\section{British Advisor Office}


Complaints that many people (Malays \& Tamils) are infringing his rights by manufacturing \& selling toddy \& asks that, if they are arrested, all fines imposed on them be given to him, in British Adviser's Office Kelantan File, BAOK $1052 / 1927$.

Increase in toddy drinking amongst certain sections of the Indian community in Malaya. Forwards of S.S. \& F.M.S despt: re asks for reports, British Adviser's Office Kelantan File, BAOK 540/1930.

Licences to the managers of Estates to supply Toddy to the Tamil Coolies on their estates, British Adviser's Office Kelantan File, BAOK 729/1916.

Number of Government, Public and Estate toddy shops in each of the Unfederated Malay States which catered to Indian labourers and the total amount of revenue derived there from during the year 1934, 1935, 1936, in British Adviser's Office Kelantan File, BAOK 87/1935.

Number of Government, Public and Estate toddy shops in each of the Unfederated Malay States which catered to Indian labourers during the year 1938, 1939, 1940, in British Adviser's Office Kelantan File, BAOK 179/1939.

Public Toddy Shop in Kelantan, in British Adviser's Office Kelantan File, BAOK 833/1937.

\section{Secretariat Files}

Estate Toddy Shops, in Perlis Secretariat File, 374. Letter from D. K. Daniels to Headquarters, British Military Administration, Malay Peninsula, KL, $17^{\text {th }}$ December 1945.

Government Policy as to toddy shop in Kuala Langat, in Selangor Secretariat File, 511/1923.

Government Policy as to sale of toddy in Ulu Langat District, in Selangor Secretariat File, 337/1923.

Governments Policy with Regard to Toddy Forward Pamphlet entitled, in Negeri Sembilan Secretariat File 2299/1922.

Government Policy with regard to Toddy, in Negeri Sembilan Secretariat File, N.S.426/1925.

Illegal Sale of Toddy, District Office Johor Bahru File, 1948-1974, DOJB 632/52.

Illegal Sale of Toddy, in District Office of Muar, 1943-1972, PDM 125/52.

Illicit Sale of Chandu \& Samsu in Central Johore, in Department of Customs \& Excise Batu Pahat File, 1945-1970, CEJ 351. Increase in the selling price of toddy, in Perlis Secretariat File, 806.

Licensing of Toddy Shop in Kuala Lumpur District, in Selangor Secretariat File, 5086/1916. Letter from Chairman, Selangor Licensing Board to Resident Selangor, Kuala Lumpur, $25^{\text {th }}$ October 1916.

Memorandum on The Question of The Re-opening of Estate Toddy Shops In Kedah \& Perlis, in Kedah Secretariat File, $228 / 46$.

Memorandum on Toddy Shops and Drunkenness by Indian Labourers, in Government Policy With Regard To Toddy, in Selangor Secretariat File, 3780/1922.

Memorandum on Toddy Shops of Estates in particular and Kelantan in general, in Report of The Estate Toddy Shop Committee, in Kelantan Secretariat File, 296/1947.

Permission to distil Toddy from the coconut trees, for their own consumption, Perlis Secretariat File, BMAP 196.

Report of The Estate Toddy Shops Committee, in Labour Department of Malaysia File, 1945-1947, LDM $426 / 46$ pt. ii.

Restriction and Additions under which toddy shops license issued to Estate Manager with F.M.S Enquires as to, in Selangor Secretariat File 3913/1920, Kuala Lumpur, $27^{\text {th }}$ July 1920.

Sale of Liquor to South Indian labourers, in District Office of Klang File, 1939-1961, PDK 517/49.

Tender for the supply of toddy to Government toddy shops during 1946, in Kedah Secretariat File, 284.

Tenders for Toddy Shop in Kuala Selangor District for 1917 Recommendations acceptance, in, Selangor Secretariat File, $5970 / 1916$.

The payment of this amount varies according to state. For example in Kedah, the amount was $\$ 50$, and in Selangor it was $\$ 100$. See, Toddy Contacts For 1952, in Kedah Secretariat File, 36/71.

Toddy Contacts For 1952, in Kedah Secretariat File, 36/71.

Toddy Farm for 1901-Tenders for, in Selangor Secretariat File 7414/1900. Letter from District Officer to Resident of Selangor, Ulu Langat, $17^{\text {th }}$ December 1900.

Toddy shop for the Estate- Petition by the Labour Force for, in Selangor Secretariat File 415/1924.

Toddy Shop Licenses of 1913, in Selangor Secretariat File, 3932/1912.

\section{Ministry / Department / District Files}

Applying for a licence to open a toddy shop at Senggarang, in Land Office of Batu Pahat File, 1914-1931, AABP 173/23.

Bekalan Tuak Borongan Ke-Atas Kedai Tuak Kerajaan Johore Baharu (1965-1966), 1948-1970, in Department of Customs \& Excise Batu Pahat, 1945-1970, KEJ 2090/Jil V.

Customs Toddy Shops, in Ministry of Labour and Manpower File, Kuala Lumpur, 1948-1962, KBTRKL 103/53.

Estate Toddy Shop Jenderata Estate, in Customs \& Excise Department, Telok Anson, Perak, File1942-1956, JKEDP $312 / 52$. 
Estate Toddy Shop (Retail), in District Office of Muar File, 1947-1961, MLB 7/55.

Government Toddy Contractor Malacca, in Labour Department of Malacca File, 1945-1954, JBM 18/49.

Illicit Samsu. Speeches by the Honourable Mr.B.J.R.Barton, State Council 24.9.35, in Ministry of Johore File, 1933-1936, MBJ 371/35.

Inspection of Toddy Tapping, in Labour Department of Malacca File, 1945-1954, 31/54.

Laws of the F.M.S. Cap. 133 Excise Ordinance Toddy Shops On Estate in Kedah, in Attorney General's Chambers Files, 1957, JPN 1210. Report J. Grundy, Commissioner for Labour, Federation of Malaya, Federal House, Kuala Lumpur, $6^{\text {th }}$ August 1957.

Miscellaneous B.M.A. Correspondence, in District Office Pekan, Pahang File, 1945-1966, PDP 3/1946.

I. Petition from Toddy Tappers against their employer KR.SP.Subramaniam Chettiar of No.82 Main Road, Balik Pulau, II. Toddy Tappers etc. for 1955, in Labour Commissioner of Penang File, 1950-1955, PBPP 103-54.

Power of Licensing Board to Restrict the hours of sale in the case of a) public house licence, b) toddy shop, in Customs Department of State of Kelantan File, 1946-1962, JKDNK 200/54.

Reports against Kathamuthu Naiker who holds a licence (wholesale) to deal in toddy, in Land Office of Batu Pahat, 1931 1946, AABP 117/33. Letter from Supt. Prev. Branch to The Asst: Adviser, Batu Pahat, 10 ${ }^{\text {th }}$ May 1933.

Supply of Toddy in Penang \& Province Wellesley, in Pulau Pinang Secretariat File, RCP/CUST/1018/1948.

Tender for the supply of Toddy to Government Toddy Shops During 1946, in Kedah Secretariat File 284.

The Toddy Tapping Industry, in Estates Toddy Shop In The State of Malacca, in Labour Department of Malacca File, 1945 1954, JBM 41/45.

The United Planting Association of Malaya: Toddy Shops, in Labour Department of Malaysia File, 1945-1947, LDM 426/46.

Toddy Committee, in Labour Department Malaysia File, 1945-1947, 426/46. Letter from Sgd. W.J.K.Stark, Malayan Representative in India to Office of the Malayan Representative in India, $24^{\text {th }}$ April 1947.

Toddy Supplier (S.Rayappan) Delivering excess toddy after the usual daily supply, in District Office of Larut \& Matang, Perak, 1926-1939, PDLM 300/39.

Toddy Yields, in Department of Customs \& Excise Batu Pahat, 1945-1970, CEJ 1029.

\section{Periodicals}

Malaya Tribune, 25 September 1935.

\section{Books}

Arasaratnam, S. (1970). Indians in Malaysia and Singapore, Kuala Lumpur: Oxford University Press.

Kalaimuthu, K. (2008). Malaysian Indians Towards a New Paradigm, Ipoh: A Malaysia Tamil Association.

Kaliaperumal, K.. (2008). Compendium On The Culture Of The Tamils, Ipoh: Vallalaar Association.

Naga Sanmugam. (1999). Thirukkural, Kural dan Penjelasan, Chennai: Kumaran Publications.

Nanjundan, S. (1950). Indians in Malayan Economy, New Delhi: Office of the Economic Adviser to the Government of India.

\section{Thesis and Dissertations}

Nagendralingan Ratnavadivel, 'The History of Toddy and its impact on the socio-economic sphere of the Indian especially in Selangor with particular reference to the district of Kuala Langat 1900-1973', B.A. Thesis, School of Humanities, University of Science Malaysia, Pulau Pinang, 1973/1974.

Daniel, J. R., 'A Socio Economic Study Of The Indians In The Rubber and Oil Palm Estates in the State of Perak and Selangor', M.A. Thesis, History Department, University of Malaya, Kuala Lumpur, 1980.

Karthiayini Katigason, 'Todi Dalam Kalangan Masyarakat India Ladang Di Selangor, 1890-1945', M.A. Dissertation, History Department, University of Malaya, Kuala Lumpur, 2010/2011.

\section{Seminars}

Jasmin Asir, "Information Regarding Toddy Drinking" in $6^{\text {th }}$ Seminar Aaivu Kovai, India: Tamil Studies, University of Kerala, Thiruvananthapuram, 1974.

Paramasivam, A., 'Toddy Drinking in Malaysia', Presentation at Seminar on Health, Food and Nutrition, Penang, 15-20 September 1979.

Sanmugam, M., "Toddy in Greek and Sangam Period", in $6^{\text {th }}$ Seminar Aaivu Kovai, in $6^{\text {th }}$ Seminar Aaivu Kovai, India: Tamil Studies, University of Kerala, Thiruvananthapuram, 1974. 


\section{Appendix 1}

Explanation on the process of toddy collection.

\section{Picture 1}

On the first day, the toddy tapper would cut 'steps' into coconut trees to facilitate in the climbing of the tree.

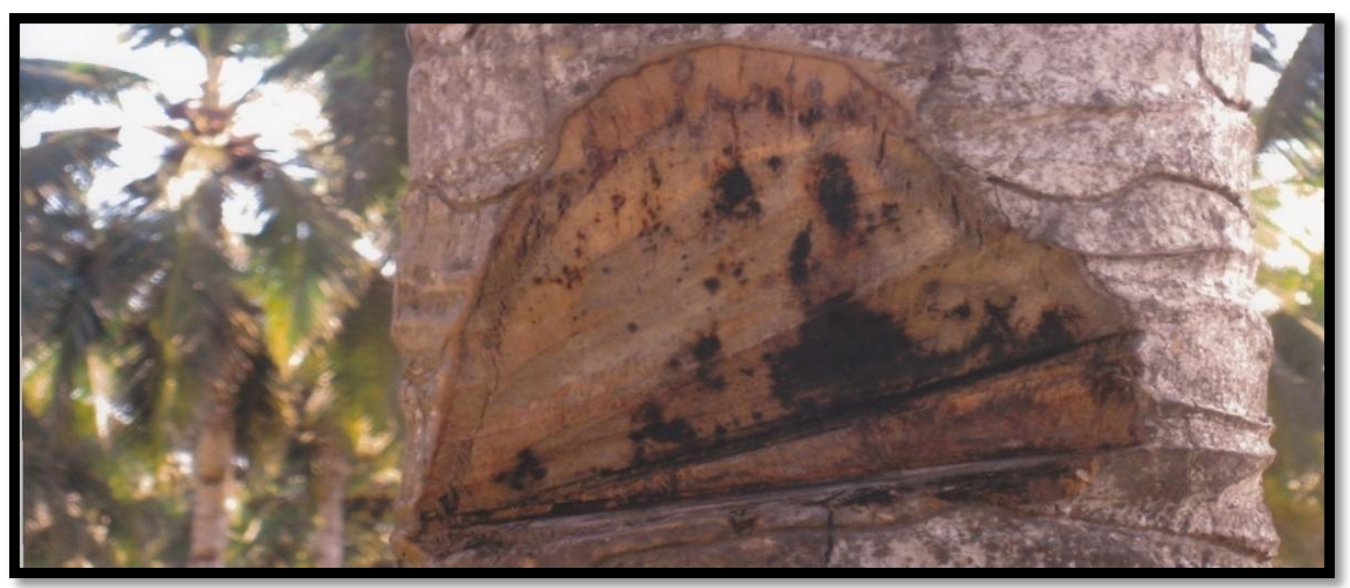

Picture 2

After the tapper is prepared to tap toddy, he would place an earthen jar at the foot of the tree and begin climbing the tree.

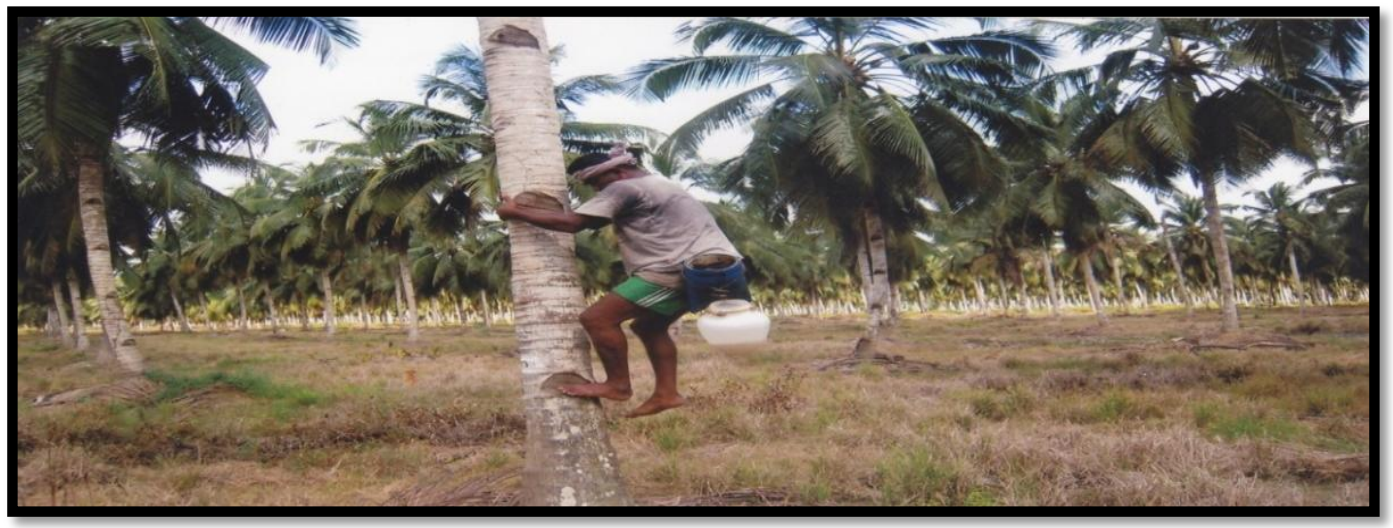

\section{Picture 3}

After he reached the top, the tapper would force the flower bud to blossom through slow knocks with a small mallet. It is then firmly tied with a type of rope / pattai (in Tamil) to avoid it from opening. 


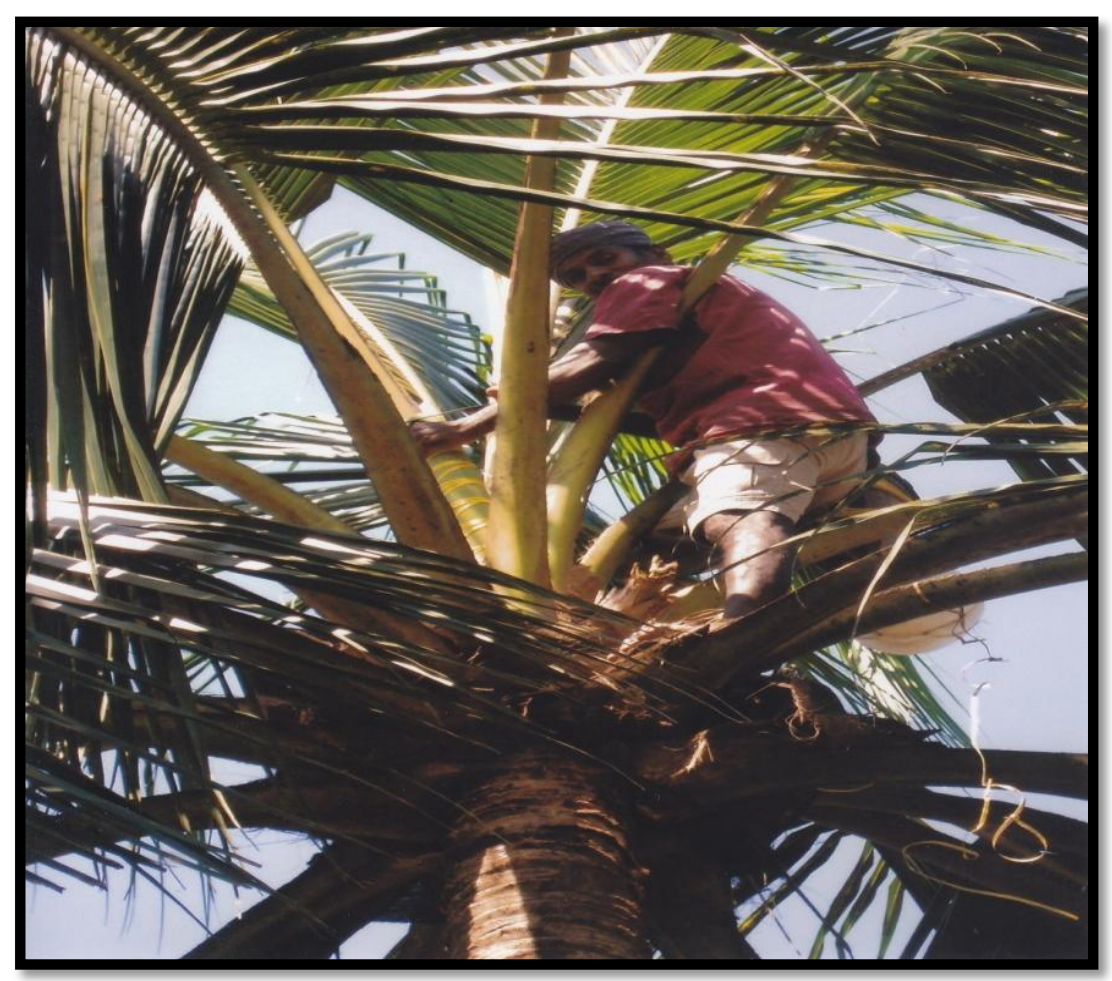

Picture 4

He then cuts the flower bud tied to the rope so as to produce a continuous source of toddy from that tree.

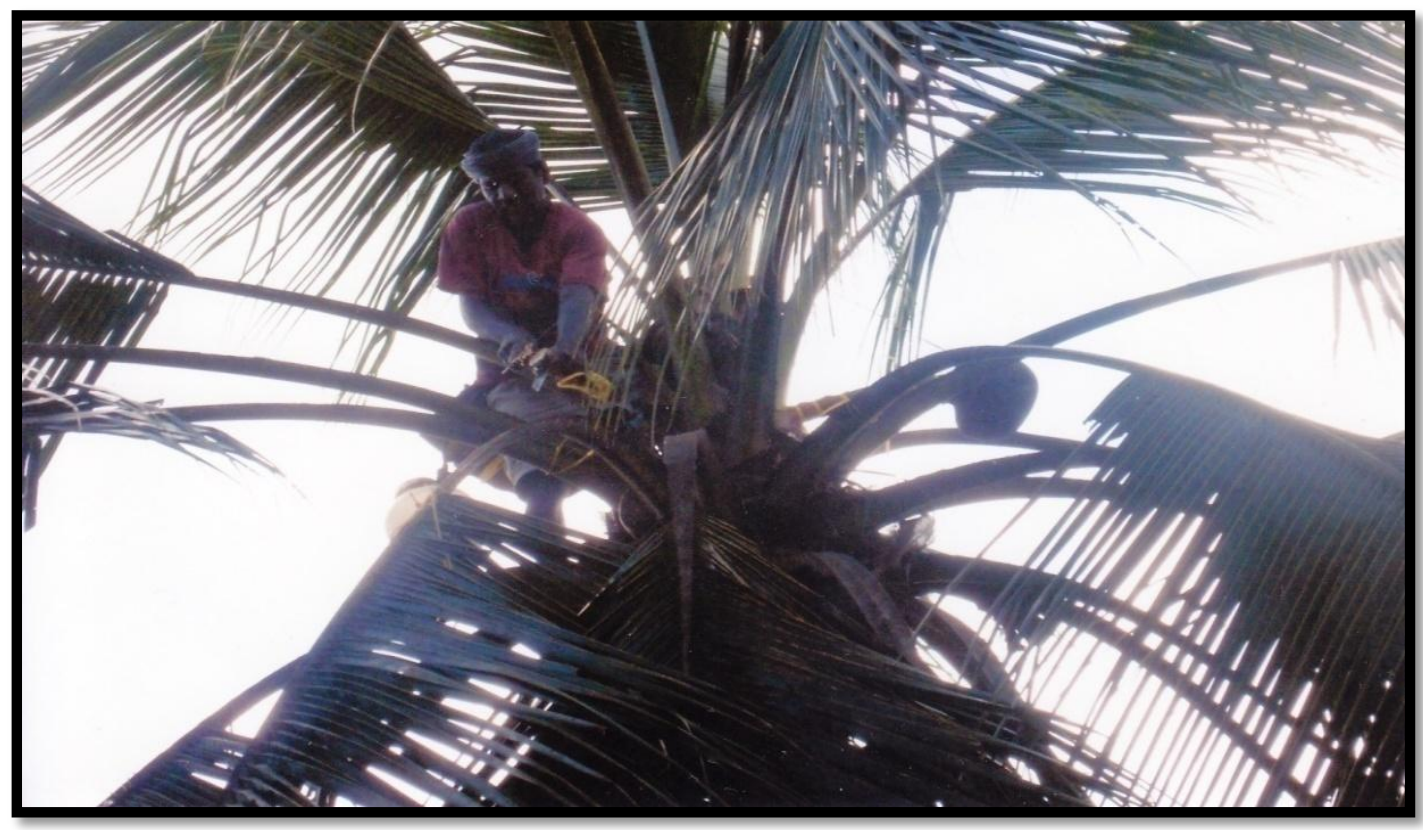

*On the second day, the coconut tree is left to 'rest' and this process would be repeated on the third and fourth days to ensure the excess production of toddy from the source. One coconut tree could produce a year's worth of toddy.

Picture 5

On the fifth day, the tapper would slowly bend the leaf blade to allow toddy to flow into the emptychatty / mutty attached to it. 


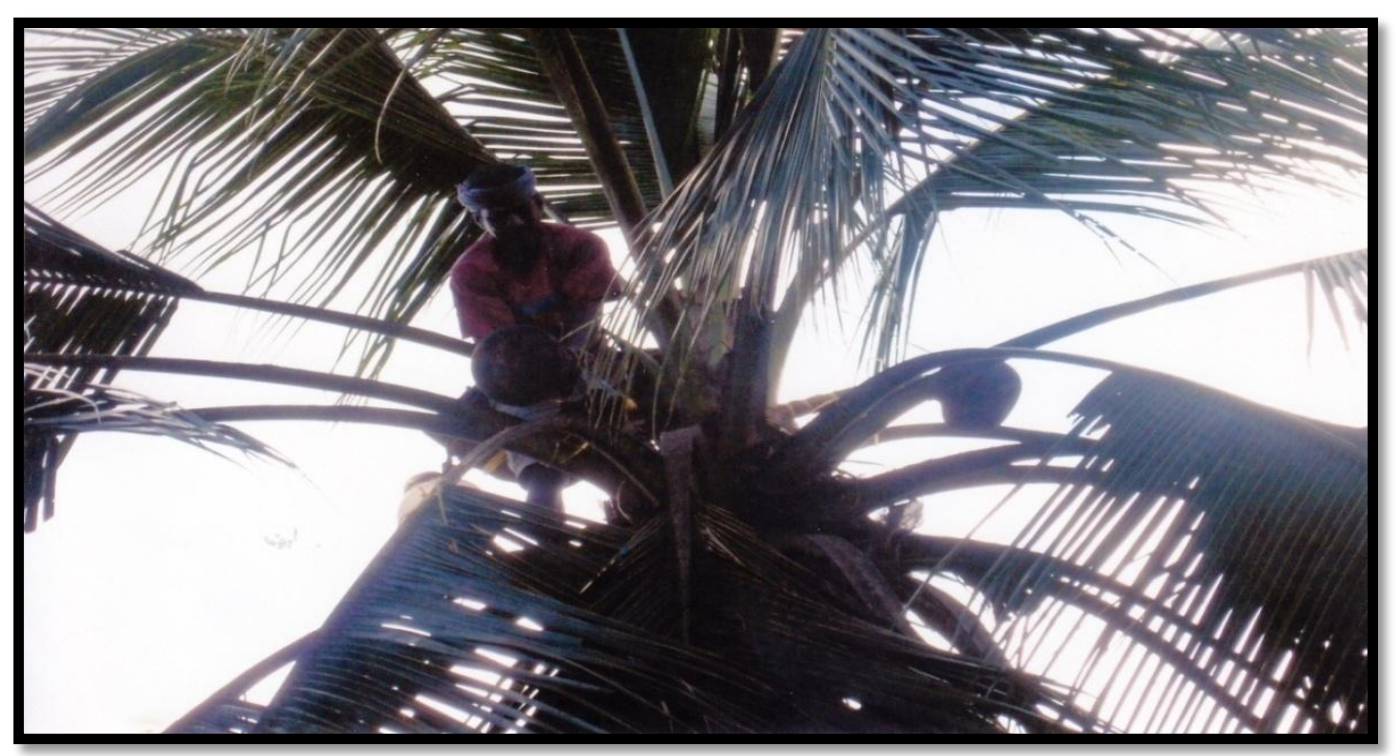

Picture 6

On the sixth day, he would collect the earthen jar tied to the leaf blade of the tree, and pour the collected toddy into a new jar. Then, he would cut the flower bud with a pruning knife and re-position the jar for another round of toddy collection.

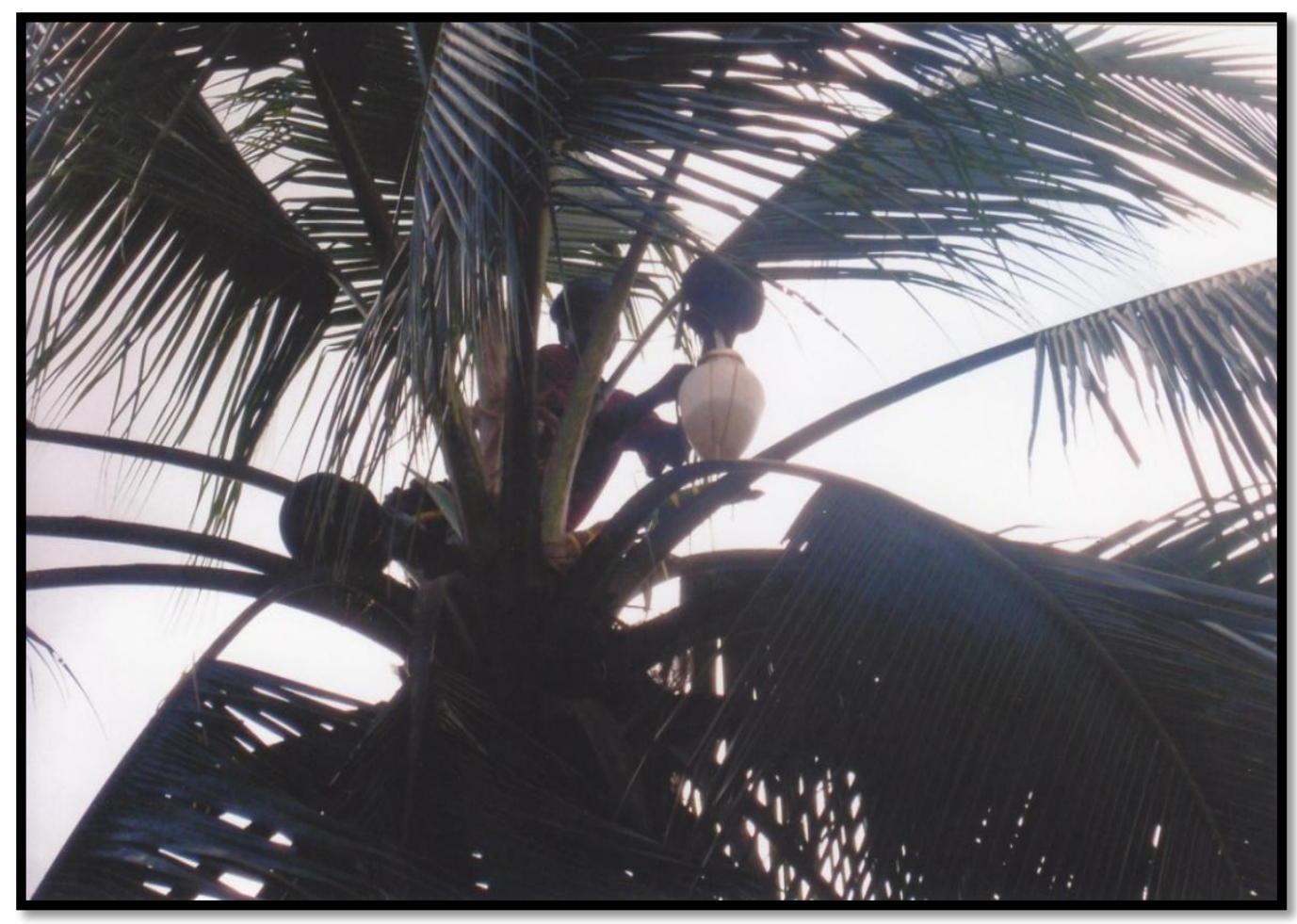


Picture 7

After completion of toddy collection, the tapper descends.

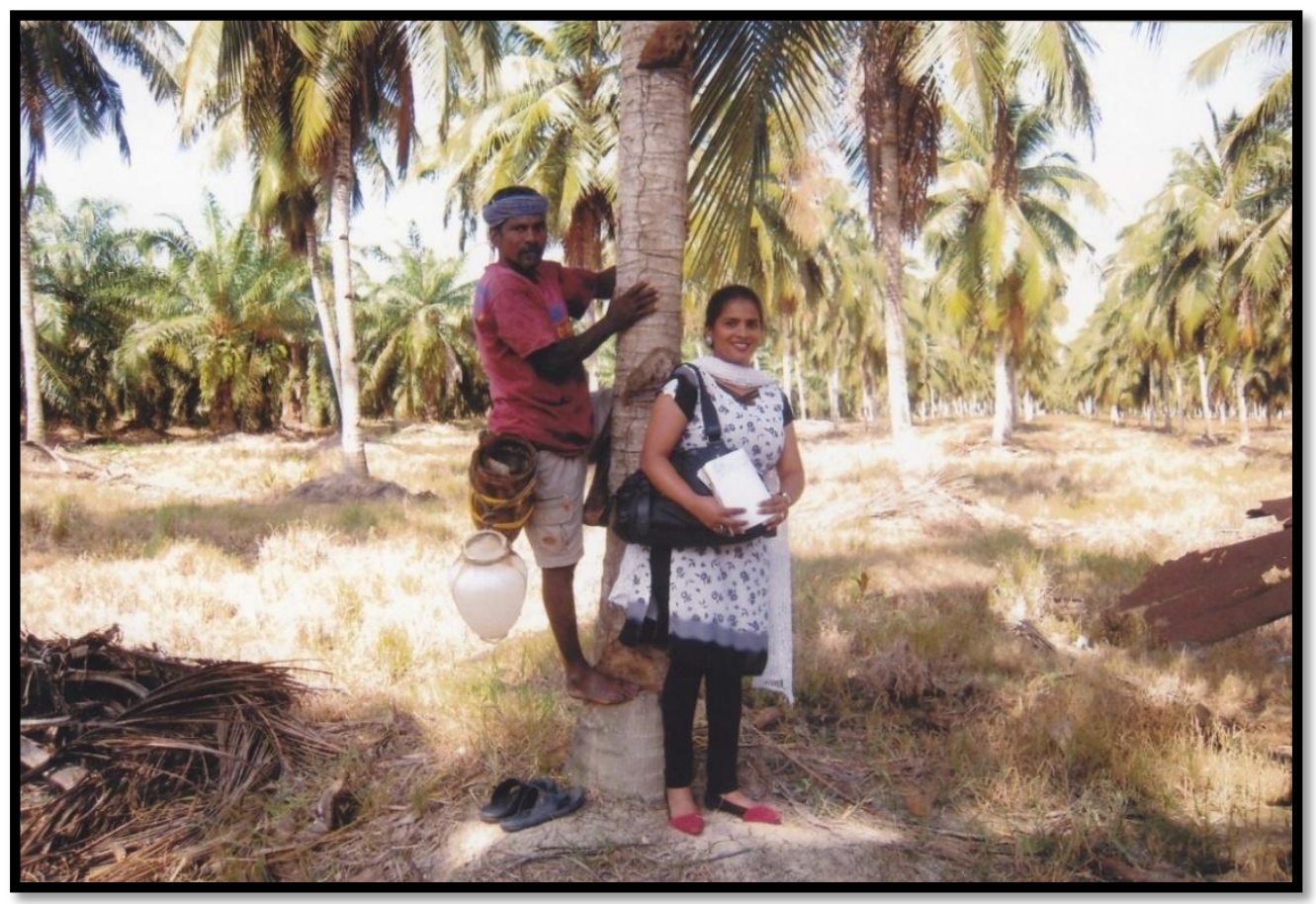

Picture 8

Later, he pours the toddy from the jar into the earthen jar/ pail placed at the foot of the tree.

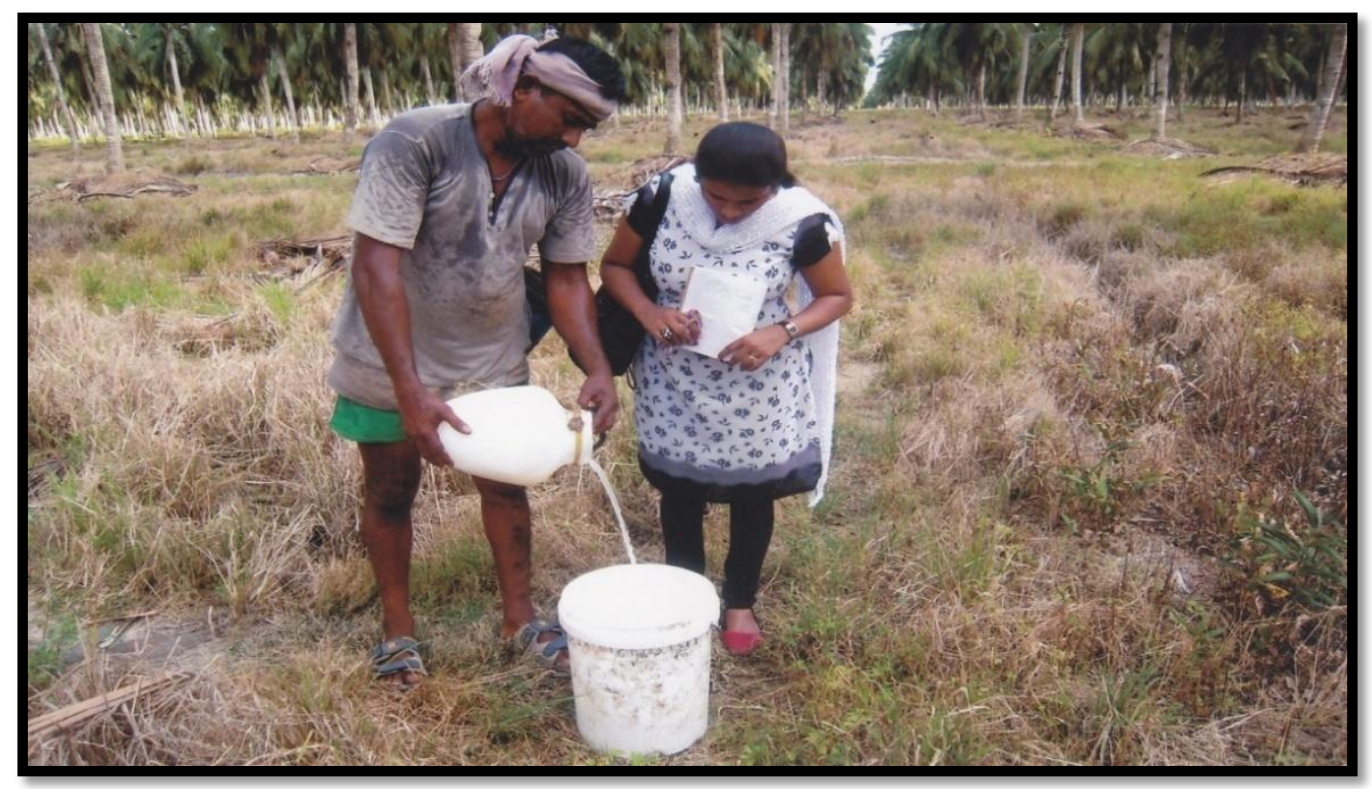

Source: All pictures are from Author's Collection. 